\title{
Synthesis and Reactivity of Rare Earth Metals Complexes with a Nitrogen Donor Ligand. Compounds in Formal Low Oxidation States
}

\author{
Dissertation \\ Zur Erlangung des Doktorgrades \\ der Mathematisch-Naturwissenschaftlichen Fakultäten \\ der Georg-August-Universität zu Göttingen
}

\author{
vorgelegt von \\ Ana-Mirela Neculai \\ geb. Gugulea \\ aus Slobozia \\ (Rumänien)
}

Göttingen 2003 
D 7

Referent: Prof. Dr. Dr. h.c. mult. H. W. Roesky

Korreferent: Prof. Dr. G. M. Sheldrick

Tag der mündlichen Prüfung: 08.05.2003 


\section{Acknowledgements}

The work described in this thesis has been carried out under the guidance and supervision of Professor Dr. Dr. h.c. mult. Herbert W. Roesky at the Institut für Anorganische Chemie der Georg-August-Universität Göttingen between June 2000 and April 2003.

My sincere thanks and gratitude are due to

\section{Prof. Dr. Dr. h.c. mult. Herbert W. Roesky}

for his constant guidance, motivation, suggestions, and discussions throughout this work. I also thank him for friendly help not only in the scientific problems.

I am grateful to Prof. Dr. Jorg Magull, Dr. Regine Herbst-Irmer, Gabor Buncoczi, Christine Schlicker, Priv. Doz. Isabel Uson, Prof. Dr. George Sheldrick, Dr. Bernhard Walfort and Prof. Dr. Dietmar Stalke for their help in the X-ray crystal structure investigations. I thank Mr. W. Zolke, Mr. R. Schöne and Dr. G. Elter (NMR division), Mr. T. Schuchard and Mrs. A. Rehbein (Mass spectral measurements), Mr. M. Hesse and Mr. H.-J. Feine (IR measurements), and the staff of the Analytical Laboratories, Mr. J. Schimkowiak and Mr. M. Schlote for their full collaboration during my research work.

I thank to Priv. Doz. Uwe Ritter, Dr. C. Ackerhans, Dr. S. Kiel, Dr. A. Mohamed, Dr. N. Mösch-Zanetti, G. Anantaraman, Y. Ding, V. Jancik, S. Kumar, K. Most, Y. Peng and many others for an excellent work atmosphere, friendliness and support.

I would like to express gratitude to Prof. Dr. Marius Andruh for his chemistry lessons and for his trust. I appreciate the encouragement from my former colleagues from the University of Bucharest and I thank them for that. The help rendered by Dr. M. Witt and Priv. Doz. I. Uson during writing this thesis is gratefully acknowledged.

I thank my 'enlarged' family who missed me during this time and I cannot thank enough to my husband Dante for his 'helping mind and hand', for his love and patience which made my work possible. 
1. INTRODUCTION 1

1.1 Objectives of the Present Work 5

2. RESULTS AND DISCUSSION 6

2.1. Solvent and Base Free $\operatorname{LLnX}_{2}(\mathrm{Ln}=\mathrm{Sc}, \mathrm{Y}$, Lu; X = Cl, Br, I;

$\left.\mathrm{L}=\mathrm{Et}_{2} \mathrm{NCH}_{2} \mathrm{CH}_{2} \mathrm{NC}(\mathrm{Me}) \mathrm{CHC}(\mathrm{Me}) \mathrm{NCH}_{2} \mathrm{CH}_{2} \mathrm{NEt}_{2}\right) \quad 6$

2.1.1. Synthesis of $\mathrm{LScCl}_{2}(\mathbf{5}), \mathrm{LScBr}_{2}(\mathbf{6}), \mathrm{LYBr}_{2}(\mathbf{7}), \mathrm{LYCl}_{2}(\mathbf{8})$, and $\mathrm{LLuCl}_{2}(\mathbf{9}) \quad 7$

2.1.2. X-ray Structural Analysis of Compounds 5, 6, and $8 \quad 8$

2.1.3. Synthesis of $\mathrm{LScI}_{2}(\mathbf{1 0})$ and $\mathrm{LYI}_{2}(\mathbf{1 1}) \quad 10$

2.2. The Adducts $\mathrm{LLaCl}_{2} \cdot \mathrm{LLi}(12)$ and $\mathrm{LCeCl}_{2} \cdot \mathrm{LLi}(13)$

2.2.1. X-ray Structural Analysis of Compounds $\mathbf{1 2}$ and $\mathbf{1 3}$

2.3. Reactivity of $\mathrm{LScX}_{2}(\mathrm{X}=\mathrm{Cl}, \mathrm{Br})$ and $\mathrm{LYCl}_{2}$

2.3.1. Synthesis of $\left[(\mathrm{L}-\mathrm{H}) \mathrm{ScCH}_{2} \mathrm{~N}\left(\mathrm{SiMe}_{3}\right)_{2}\right]_{2}(\mathbf{1 4}) \quad 15$

2.3.1.1. X-ray Structural Analysis of $\mathbf{1 4}$ and NMR Discussion 17

2.3.2. Synthesis of $\operatorname{LSc}\left(\mathrm{SO}_{3} \mathrm{CF}_{3}\right)_{2}(\mathbf{1 5}) \quad 19$

2.3.2.1. X-ray Structural Analysis of $\mathbf{1 5}$

2.3.3. Synthesis of $\left(\mathrm{Me}_{3} \mathrm{ClSn}-\mu-\mathrm{F}\right)_{2} \mathrm{LSc}(\mathbf{1 6})$

and $\left(\mathrm{Me}_{3} \mathrm{BrSn}-\mu-\mathrm{F}\right)_{2} \mathrm{LSc}(\mathbf{1 7 a}, \mathbf{1 7 b})$

2.3.3.1. X-ray Structural Analysis of $\mathbf{1 7} \quad 21$

2.3.4. Synthesis of Yttrium Dimer $\left[\mathrm{LY}\left(\mathrm{N}\left(\mathrm{SiMe}_{3}\right)\left(\mathrm{SiMe}_{2}\right) \mathrm{NH}\right]_{2}(\mathbf{1 8}) \quad 23\right.$

2.3.4.1 X-ray Structural Analysis of $\mathbf{1 8} 25$

2.4. Compounds in Formal Low Oxidation States 26

2.4.1. Synthesis of Sandwich $\mathrm{Sc}(\mathrm{I})$ Complex (LMgBr$)_{2} \mathrm{ScBr}(\mathbf{1 9})$

2.4.1.1. X-ray Structural Analysis and Discussion

of the Structure of 19 
2.4.1.2 Theoretical Calculations on $\mathbf{1 9}$

2.4.1.3. Reaction of $(\mathrm{LMgBr})_{2} \mathrm{ScBr}(19)$ with water. Synthesis of $\mathrm{LSc}\left(\mathrm{OB}\left(\mathrm{C}_{6} \mathrm{~F}_{5}\right)_{2}\right)_{2}(\mathbf{2 0})$

2.4.1.4. X-ray Structural Analysis of 20

2.4.1.5. Reaction of $(\mathrm{LMgBr})_{2} \mathrm{ScBr}(\mathbf{1 9})$ with $\left(\mathrm{HOCH}_{2}\right)_{2} \mathrm{C}\left(\mathrm{CH}_{3}\right)_{2}$. Synthesis of $\operatorname{LMgBr}(\mathbf{2 1})$

2.4.1.6. X-ray Structural Analysis of 21

2.4.2. Synthesis of Cluster $\mathrm{Lu}_{2} \mathrm{Mg}_{4} \mathrm{Cl}_{10} \mathrm{O}_{2} \cdot 6 \mathrm{THF}$ (22) 38

2.4.2.1. X-ray Structural Analysis of 22

2.4.3. Synthesis of adducts $(\mathrm{LLi})_{2} \mathrm{SmI}_{2}(\mathbf{2 3})$ and $(\mathrm{LLi})_{2} \mathrm{YbI}_{2}(\mathbf{2 4})$

2.4.3.1 X-ray Structural Analyses of $\mathbf{2 3}$ and $\mathbf{2 4} 42$

3. SUMMARY AND CONCLUSIONS 45

4. EXPERIMENTAL SECTION 52

4.1. General Procedures 52

4.2. Physical Measurements 52

4.3. Starting Materials $\quad 54$

4.4.1. Synthesis of $\mathrm{LScCl}_{2}(\mathbf{5}), \mathrm{LScBr}_{2}(\mathbf{6}), \mathrm{LYBr}_{2}(\mathbf{7}), \mathrm{LYCl}_{2}(\mathbf{8})$, and $\mathrm{LLuCl}_{2}(\mathbf{9})$

4.4.2. Synthesis of $\mathrm{LScI}_{2}(\mathbf{1 0})$ and $\mathrm{LYI}_{2}(\mathbf{1 1})$

4.4.3. Synthesis of $\mathrm{LLaCl}_{2} \cdot \operatorname{LLi}(\mathbf{1 2})$ and $\mathrm{LCeCl}_{2} \cdot \operatorname{LLi}(\mathbf{1 3})$

4.4.4. Synthesis of $\left[(\mathrm{L}-\mathrm{H}) \mathrm{ScN}\left(\mathrm{SiMe}_{3}\right)_{2}\right]_{2}(\mathbf{1 4}) \quad 57$

4.4.5. Synthesis of $\mathrm{LSc}\left(\mathrm{SO}_{3} \mathrm{CF}_{3}\right)_{2}(\mathbf{1 5}) \quad 58$

4.4.6. Synthesis of $\left(\mathrm{Me}_{3} \mathrm{ClSn}-\mu \text {-F }\right)_{2} \mathrm{LSc}(\mathbf{1 6})$ and $\left(\mathrm{Me}_{3} \mathrm{BrSn}-\mu-\mathrm{F}\right)_{2} \mathrm{LSc}(\mathbf{1 7 a}, \mathbf{1 7 b})$

4.4.7 Synthesis of $\left[\mathrm{LY}\left(\mathrm{N}\left(\mathrm{SiMe}_{3}\right)\left(\mathrm{SiMe}_{2}\right) \mathrm{NH}\right]_{2}(\mathbf{1 8})\right.$ 
4.4.8. Synthesis of $(\mathrm{LMgBr})_{2} \mathrm{ScBr}(\mathbf{1 9}) \quad 59$

4.4.9. Synthesis of $\operatorname{LSc}\left(\mathrm{OB}\left(\mathrm{C}_{6} \mathrm{~F}_{5}\right)_{2}\right)_{2}(\mathbf{2 0}) \quad 60$

4.4.10. Synthesis of $\operatorname{LMgBr}(\mathbf{2 1}) \quad 60$

4.4.11. Synthesis of $\mathrm{Lu}_{2} \mathrm{Mg}_{4} \mathrm{Cl}_{10} \mathrm{O}_{2} \cdot 6 \mathrm{THF}$ (22) 61

4.4.12 Synthesis of $(\mathrm{LLi})_{2} \mathrm{SmI}_{2}(\mathbf{2 3}) \quad 61$

4.4.13 Synthesis of $(\mathrm{LLi})_{2} \mathrm{YbI}_{2}(\mathbf{2 4}) \quad 62$

4.5. NMR and GC-MS Experiments 62

5. HANDLING AND DISPOSAL OF SOLVENTS
AND RESIDUAL WASTE

6. CRYSTAL DATA AND REFINEMENT DETAILS 65

7. REFERENCES 83 


\section{Abbreviations}

av

br

C

C. N.

$\mathrm{Cp}$

d

DFT

DME

$\delta$

EI

Et

${ }^{i} \mathrm{Pr}$

HSAB

$J$

K

L

Ln

$\lambda$

$\mathrm{m}$

$M^{+}$

MAS

$\mathrm{Me}$

$m / z$

MS

$\mu$

NMR

$\mathrm{Ph}$

ppm

$\mathrm{R}$ average

broad

Celsius

coordination number

cyclopentadienyl

doublet, days

Density Functional Theory

dimethylethoxide

chemical shift

electron impact ionization

ethyl

isopropyl

hard and soft acid and base

coupling constant

Kelvin

$\mathrm{Et}_{2} \mathrm{NCH}_{2} \mathrm{CH}_{2} \mathrm{NC}(\mathrm{Me}) \mathrm{CHC}(\mathrm{Me}) \mathrm{NCH}_{2} \mathrm{CH}_{2} \mathrm{NEt}_{2}$

rare earth metal

wavelength

multiplet

molecular ion

Magic Angle Spinning

methyl

mass/charge

mass spectrometry

bridge

nuclear magnetic resonance

phenyl

parts per million

organic substituent 
S

$\mathrm{t}$

${ }^{t} \mathrm{Bu}$

THF

TMS

Z

$\mathrm{X}$ singlet

triplet

tertbutyl

tetrahydrofuran

tetramethylsilane

number of molecules in the unit cell

halogen 


\section{Introduction}

The elements of the $3^{\text {rd }}$ Group of the Periodical System: scandium, yttrium, lanthanum and the lanthanides are generally known as Rare Earth Elements. ${ }^{[1]}$ The name has its origin in the elements discovery. Most of them have been found as oxides in two minerals, "Ytterbit" and "Cerit", and according to the time were called "earths" and apparently they were rare. Later, it was proven that the name is by no means justified by their occurrence in nature, unusual properties or their relevance in common life. ${ }^{[2]}$ The reason of including yttrium in the same category of elements with lanthanides (or lanthanoids according to the IUPAC rules, ${ }^{[1 b]}$ elements characterized by gradual filling of the $4 \mathrm{f}$ subshell) is linked to the phenomenon of lanthanides contraction. This is an outcome of the poor shielding of the $4 \mathrm{f}$ electrons that is manifested by the increase of the effective nuclear charge and simultaneous reduction in size with the atomic number along the lanthanides series. On this basis the $\mathrm{Y}^{3+}$ radius and consequently the properties are similar to $\mathrm{Ho}^{3+}$. Scandium radius is far too small to obey the above classification but its properties make it a candidate for connecting the lanthanides and the transition metals showing increasing interest in its chemistry. ${ }^{[3]}$

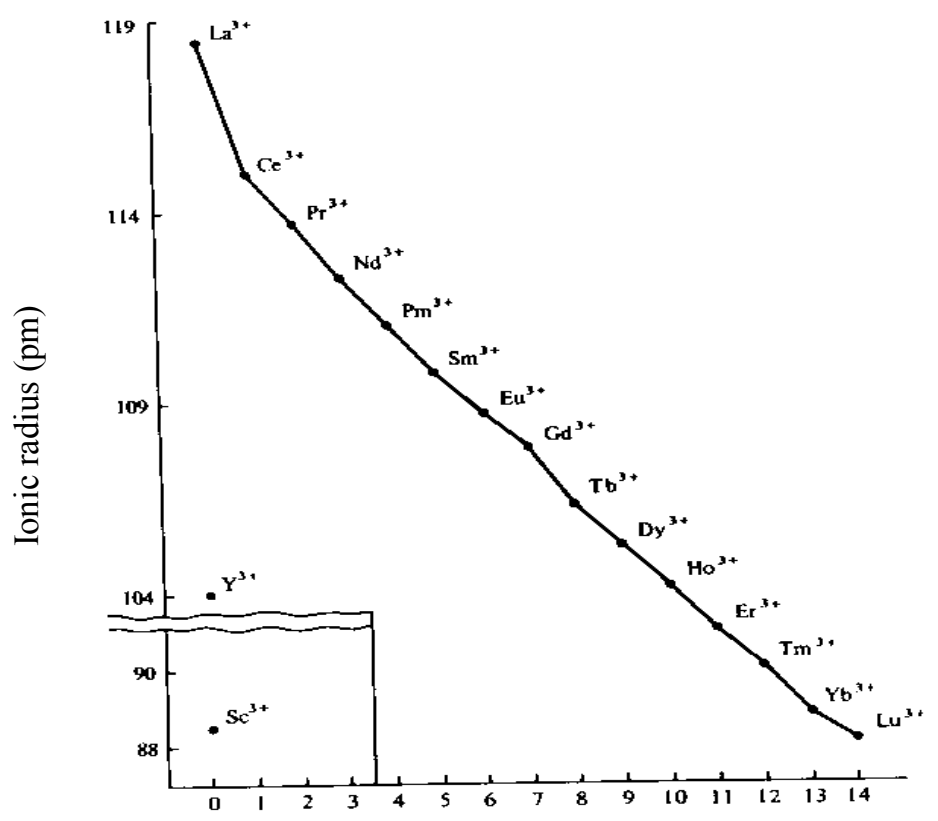


Number of $f$ electrons

Figure 1: Ionic radii $(C . N .=6)$ of rare earths metals. ${ }^{[3]}$

The extraordinary development of the organometallic chemistry of rare earth metals in the last 30 years, almost 200 years after their discovery, is closely associated to the cyclopentadienyl ligand. The first well-characterized organometallic compounds of rare earths were tricyclopentadienyl derivatives obtained by stoichiometric reactions of NaCp with anhydrous halogenides. ${ }^{[4]}$ The importance of the $\mathrm{Cp}$ moiety as an ancillary ligand, offering to the complexes stability and solubility, was fully exploited giving rise to a plethora of compounds ${ }^{[5]}$ most of them of the type $C p_{2} \operatorname{LnX}$.

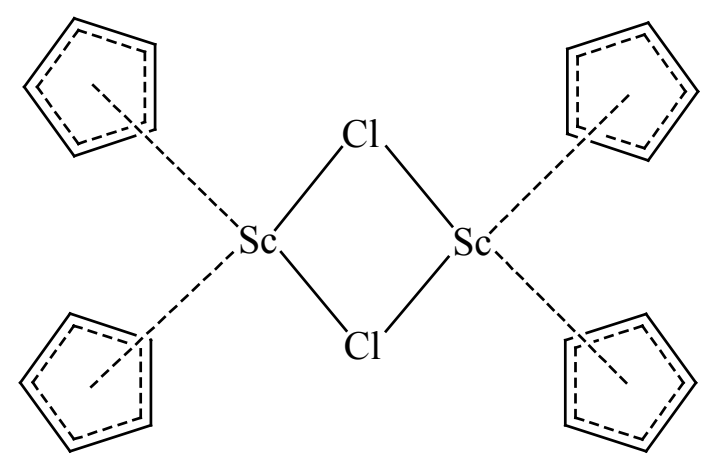

Figure 2: First X-ray structural characterized complex of the type $\mathrm{Cp}_{2} \mathrm{LnX}, \mathrm{Cp}{ }_{2} \mathrm{ScCl}(\mathbf{1}) \cdot{ }^{[6]}$

Once it was proved that lanthanide compounds have a remarkable importance in organic synthesis, ${ }^{[7]}$ catalysis, ${ }^{[8]}$ and even in the every day life,${ }^{[1,9]}$ the ligands area expanded rapidly from substituted cyclopentadienyls, ${ }^{[10]}$ to functionalized cyclopentadienyls, ${ }^{[11]}$ beyond the lantanoidocene area. Last decade examples include heterocyclopentadienyls, ${ }^{[12]}$ tripodal ligands, ${ }^{[13]}$ cyclooctatetraene and substituted cyclooctatetraenes, ${ }^{[14]}$ deprotonated mono- and diaza- crown ethers, ${ }^{[15]}$ aminotroponiminates, ${ }^{[16]}$ benzamidinates,${ }^{[17]}$ terphenyls, ${ }^{[18]}$ pyrazolylborates, ${ }^{[19]}$ porphyrine and porphyrine derivatives, ${ }^{[20]}$ and others. ${ }^{[21]}$

The ligand design ${ }^{[22]}$ is associated to the predicted properties of the final organometallic compounds and it is based on the well-known chemical, structural and physical information concerning the class of the rare earth metals. These are:

1. they are considered as hard acids ("a" character). ${ }^{[23]}$ 
2. the rare earths have relatively big ionic radii in comparison with other transition metals. ${ }^{[3]}$

3. they are usually found in nature with the formal oxidation state +3 ; for samarium, europium, and ytterbium +2 is also easily available; cerium can adopt in its compounds the formal oxidation state +4 .

The "a" character explains why the most stable rare earth metal complexes contain chelating oxygen ligands; ${ }^{[24]}$ ligands with sulfur or phosphorus donor atoms are less frequent. ${ }^{[25,26]}$

An outcome of their size is their preference for high coordination numbers. Therefore the number of the monoanionic derivatives of type $\mathrm{LLnX}_{2}(\mathrm{~L}=$ ancillary monoanionic ligand that can be cyclopentadienyl, ${ }^{[26]}$ or non-cyclopentadienyl; $\mathrm{X}=$ halogen, alkyl or other simple substituents) is noticeably smaller than the corresponding diancillary complexes. Even work with ligands with considerable steric demand makes synthesis of the first type of complexes difficult due to persistent Lewis base complexation (basic solvents or alkali metal halides). In the synthesis of the halogeno precursors, also in the case of iodine, the results can be in many circumstances, oligomeric structures or clusters ${ }^{[27,28]}$ or the compounds can be "ate" complexes by incorporating alkali halogenides in their structure. They can be prepared by reactions of $\mathrm{LnX}_{3}$ with the lithium, sodium or thallium salts of the respective ligand. ${ }^{[29,30,31]}$

$$
\mathrm{LnX}_{3}+\mathrm{LLi}(\mathrm{LNa}, \mathrm{CpTl}) \rightarrow \mathrm{LLnX}_{2}
$$

Equation 1

Although complexes with monoanionic ligands $\operatorname{LLnX}_{2}(\mathrm{X}=$ halogen $)$ free of coordinated solvent or alkali metal halogenides have been reported, up to our report from 2001, none have been characterized by X-ray crystallography. ${ }^{[32]}$

Even if most of the developed chemistry contains the rare earth elements in the formal oxidation state +3 , the lower oxidation states have also attracted attention due to their unusual properties (i.e. potential new catalysts) and as scientific curiosities. The oxidation state +2 is easily accessible for $\mathrm{Eu}, \mathrm{Yb}$, stabilized by the half-filled and filled subshells, and Sm. Their organo derivatives of type RLnX (Ln $=\mathrm{Sm}, \mathrm{Yb}, \mathrm{Eu})$ are regarded as Grignard analogues and they are used as alkylating agents and in organic 
synthesis usually prepared in situ by reaction of the Ln metal with the corresponding alkyl halide. ${ }^{[33,34]}$

As far as the other rare earth metals are concerned, apart of the compounds integrated in the solid state chemistry, ${ }^{[35]}$ there are few examples of molecular complexes known, preferentially prepared by metal vapor synthetic techniques. ${ }^{[36]}$ According to this route, several subvalent scandium complexes have been obtained by Cloke, Nixon et $a l .^{[37,38]}$

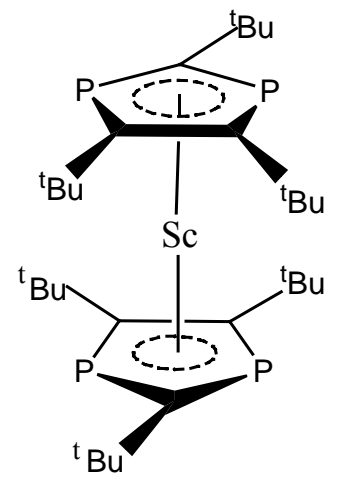

2

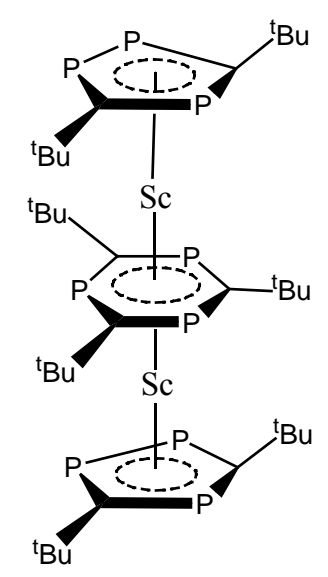

3

Figure 3: Two subvalent scandium complexes prepared by metal vapor techniques. ${ }^{[37,38]}$

Two particular exceptions are the first molecular thulium(II) complex, $\mathrm{TmI}_{2}(\mathrm{DME})_{3},{ }^{[39,40]}$ and the first subvalent lanthanum compound prepared by Lappert et al. ${ }^{[41]}\left[\mathrm{K}\left(18\right.\right.$-crown-6) $\left.\left(\mathrm{C}_{6} \mathrm{H}_{6}\right)_{2}\right]\left[\left(\mathrm{Cp}^{\mathrm{tt}}{ }_{2} \mathrm{La}\right)_{2}\left(\mathrm{C}_{6} \mathrm{H}_{6}\right)\right] \cdot 2 \mathrm{C}_{6} \mathrm{H}_{6}\left(\mathrm{Cp}^{\mathrm{tt}}=1,3-{ }^{t} \mathrm{Bu}_{2} \mathrm{C}_{5} \mathrm{H}_{3}\right)$. They were obtained by reduction methods, the first of $\mathrm{TmI}_{3}$ with metallic $\mathrm{Tm}$ in DME, and the second of $\mathrm{Cp}^{\mathrm{tt}}{ }_{3} \mathrm{La}$ with $\mathrm{K}$ and 18-crown-6 in benzene. Organic solvent adducts of neodymium and dysprosium diiodide were obtained at high temperatures $\left(>200^{\circ} \mathrm{C}\right)$ from the respective metal powder and iodine in sealed glass ampoules followed by treatment of the reaction products with DME or THF. ${ }^{[42]}$

The stable oxidation state +4 is so far well represented only for Cerium compounds. The $\mathrm{Ce}^{4+}$ compounds are important reagents in preparative and analytical chemistry. ${ }^{[23]}$ 
The main motivation for the assiduous research in the field of the rare earth metals chemistry is, without any doubt, their role in catalysis and other peculiar properties. The high Lewis acidity make them good catalysts in ring-opening polymerization reactions. ${ }^{[43,44]} \mathrm{Sc}(\mathrm{OTf})_{3}$ is already produced on commercial scale. They are also efficient for a range of olefin transformations such as hydrogenation, ${ }^{[45]}$ hydrosilylation, ${ }^{[46]}$ polymerization, ${ }^{[47]}$ hydroboration, ${ }^{[48]}$ hydroamination, ${ }^{[49]}$ and reductive or silylative cyclization of $\alpha, \omega$-dienes, ${ }^{[50]}$ and also for $\sigma$-bond activation. ${ }^{[51]}$ Taking advantage of the chiral ligands these processes can be enantioselective. ${ }^{[52]}$ Their luminescent properties are continuously subject of remarkable applications. ${ }^{[53]}$

\subsection{Objectives of the Present Work}

In the light of the background material presented above, it is obvious that due to their multidisciplinary character the rare earth elements play a significant role in the development of our scientific and industrial life. More explicitly, in the previous decades their use in various organic technological processes led to a rapid growth especially in the field of the complexes with cyclopentadienyl ligands and derivatives. Efforts to substitute the ligands under cyclopentadienyl umbrella are appropriate especially since the rare earths have tunable steric demands. It is also true that the complexes with monoanionic ancillary ligands may be promising precursors for catalysis but were not yet fully explored.

On the other hand, compounds with rare earth elements in low oxidation states proved to be very useful, and enlargement of the number of the rare earth metals who can function in these oxidation states is a challenge.

Hence, the aims of the present work have been:

1. to synthesize and characterize dihalogeno derivatives with monoanionic ligands of the rare earths free of coordinated molecules of solvent and alkali metals salt.

2. to analyze the reactivity of these compounds in metathesis reactions.

3. to synthesize, for the first time in solution, a molecular scandium(I) compound. This aim arises from the special position of scandium in the Periodic System as 
the first transition element with properties similar to aluminum and also to the rare earths. ${ }^{[3]}$ 


\section{Results and Discussion}

\subsection{Solvent and Base Free $\operatorname{LLnX}_{2}(\mathrm{Ln}=\mathrm{Sc}, \mathrm{Y}, \mathrm{Lu} ; \mathrm{X}=\mathrm{Cl}, \mathrm{Br}, \mathrm{I} ; \mathrm{L}=$ $\left.\mathrm{Et}_{2} \mathrm{NCH}_{2} \mathrm{CH}_{2} \mathrm{NC}(\mathrm{Me}) \mathrm{CHC}(\mathrm{Me}) \mathrm{NCH}_{2} \mathrm{CH}_{2} \mathrm{NEt}_{2}\right)$}

The efforts of the last years to expand the chemistry of lanthanides beyond the well-known cyclopentadienyl derivates have resulted in a plethora of new complexes with nitrogen based ligands. ${ }^{[54-57]}$ In view of the current interest in these compounds as precatalysts ${ }^{[58]}$ we have initiated studies in new ligand systems.

Ligands containing the $\beta$-diketiminato backbone offer possibilities of stabilization for unusual bonding situations which have been exploited for various main group and transition metal complexes. ${ }^{[59]}$ The $\beta$-diketiminato compound $\mathrm{LH}$ (L $=$ $\left.\mathrm{Et}_{2} \mathrm{NCH}_{2} \mathrm{CH}_{2} \mathrm{NC}(\mathrm{Me}) \mathrm{CHC}(\mathrm{Me}) \mathrm{NCH}_{2} \mathrm{CH}_{2} \mathrm{NEt}_{2}\right)$ used in this study offers the advantage of the two incorporated donor arms which can compensate the Lewis acidity and the propensity to adopt higher coordination numbers of the rare earth metals. ${ }^{[32]}$

Complexes of type $\mathrm{LLnX}_{2}(\mathrm{~L}=$ monoanionic ancillary ligand) can be starting materials for compounds in low oxidation states obtained by reduction methods and precursors for catalytically active dialkyls. In both cases it is preferable to avoid coordinated solvents, usually THF, which can arise from the utilized adducts as starting materials $\mathrm{LnX}_{3} \cdot n \mathrm{THF}$ or from the solvent used in metathesis reactions (first because THF can interfere with the reduction process under polymerization, and second, the catalytic activity in polymerization reactions is severely inhibited in the presence of coordinated THF). ${ }^{[6]}$ 'Ate' complexes are also unfavorable. The ligand shown in Figure 4 fulfills the conditions for preventing these inconveniencies.

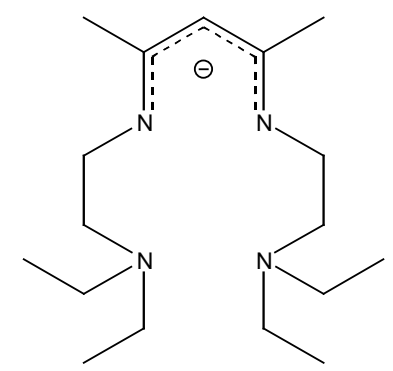

4

Figure 4: Monoanionic, $\beta$-diketiminato ligand $L^{-}$used in this study. 


\subsubsection{Synthesis of $\operatorname{LScCl}_{2}(5), \operatorname{LScBr}_{2}(6), \mathrm{LYCl}_{2}(7), \mathrm{LYBr}_{2}(8)$, and $\mathrm{LLuCl}_{2}(9)$}

Reaction between the lithium salt of the ligand LH, LLi, and an equimolar quantity of anhydrous $\mathrm{ScCl}_{3}, \mathrm{ScBr}_{3}, \mathrm{YBr}_{3}, \mathrm{YCl}_{3}$, and $\mathrm{LuCl}_{3}$, respectively, in toluene solution at reflux temperature for 12 to $48 \mathrm{~h}$ yield the colorless to slightly yellow complexes 5 - 9 in good yields (from 75 to $90 \%$ ). ${ }^{[61]}$ (Scheme1)

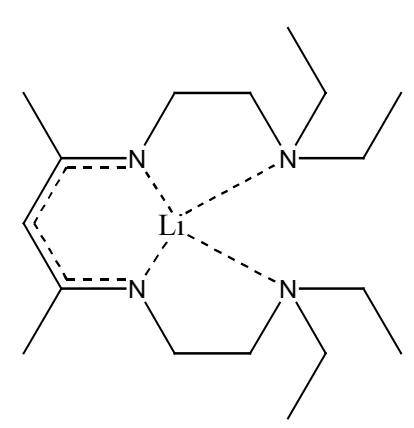

Scheme 1

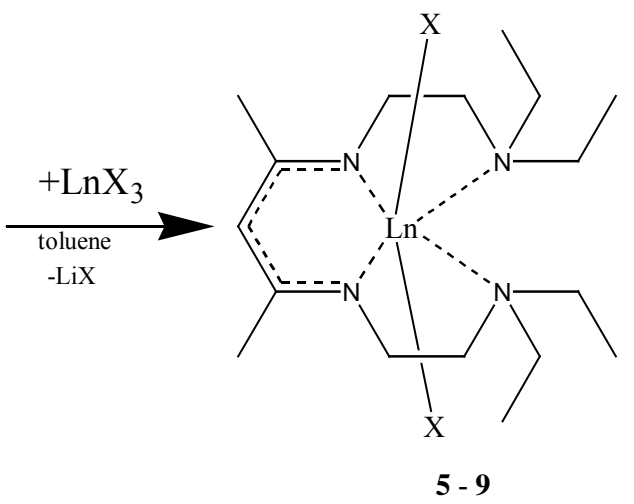

$\mathrm{Ln}=\mathrm{Sc}, \mathrm{Y}, \mathrm{Lu} ; \mathrm{X}=\mathrm{Cl}, \mathrm{Br}$

These compounds are soluble in THF, dichloromethane, and toluene $\left(\mathrm{LLuCl}_{2}(\mathbf{9})\right.$ is not very soluble in toluene). It has to be noticed that $\mathbf{5 - 9}$ are free of coordinated solvent molecules and $\mathrm{LiCl}$ or $\mathrm{LiBr}$ as observed in the structural analysis and $\mathrm{NMR}$ spectra. Complex 5 was obtained by an alternative procedure using as starting material $\mathrm{ScCl}_{3} \cdot 3 \mathrm{THF}$ under milder conditions (r.t.) with THF as solvent. Even in this case no solvent molecule coordinated to the scandium atom (in the IR spectra the characteristic bands from $1010 \mathrm{~cm}^{-1}$ and $865 \mathrm{~cm}^{-1}$ of the coordinated THF are missing) is observable.

Although dihalo Sc- $\beta$-diketiminato complexes have been used successfully for the synthesis of corresponding dialkyl derivatives and of a cationic species, ${ }^{[30,47 \mathrm{~d}, 62]}$ those free of solvent were not characterized by X-ray measurements. In the case of Y and Lu these are the first examples of $\beta$-diketiminato complexes.

All five compounds have been characterized by NMR spectroscopy (they are diamagnetic) and other analytical techniques. Under electron impact mass spectral conditions $(70 \mathrm{eV})$, the molecules remain intact (peaks due to the $M^{+}$fragments at $\mathrm{m} / \mathrm{z}$ $410,500,454,541,544$, respectively). 


\subsubsection{X-ray Structural Analyses of Compounds 5, 6, and 8}

Crystals suitable for X-ray analysis of compounds $\mathbf{5}, \mathbf{6}$, and $\mathbf{8}$ were obtained by concentration and cooling at $-26^{\circ} \mathrm{C}$ of the mother liquor overnight. The same procedure applied for compounds $\mathbf{7}$ and $\mathbf{9}$ led to twinned crystals; their analysis established the connectivity of the structure but cannot be taken into account in the discussion of bonds and angles. Compound $\mathbf{8}$ contains in the asymmetric unit molecule of toluene.

For compound $\mathbf{5}$ a local distortion can be observed due to the different orientation of one of the ethyl groups from one of the arms. This led to crystallization in two forms, one in the monoclinic space group $P 2_{1} / c$ (5a) and the second in the orthorhombic space group of higher symmetry $P c a 2_{1}(\mathbf{5 b})$ shown in Figure 5. Compounds 6 and $\mathbf{8}$ crystallize in the monoclinic space group $P 2_{1} / n$. The final refined molecular structure of $\mathbf{8}$ is shown in Figure 6. Compound 6 possesses a similar structure.

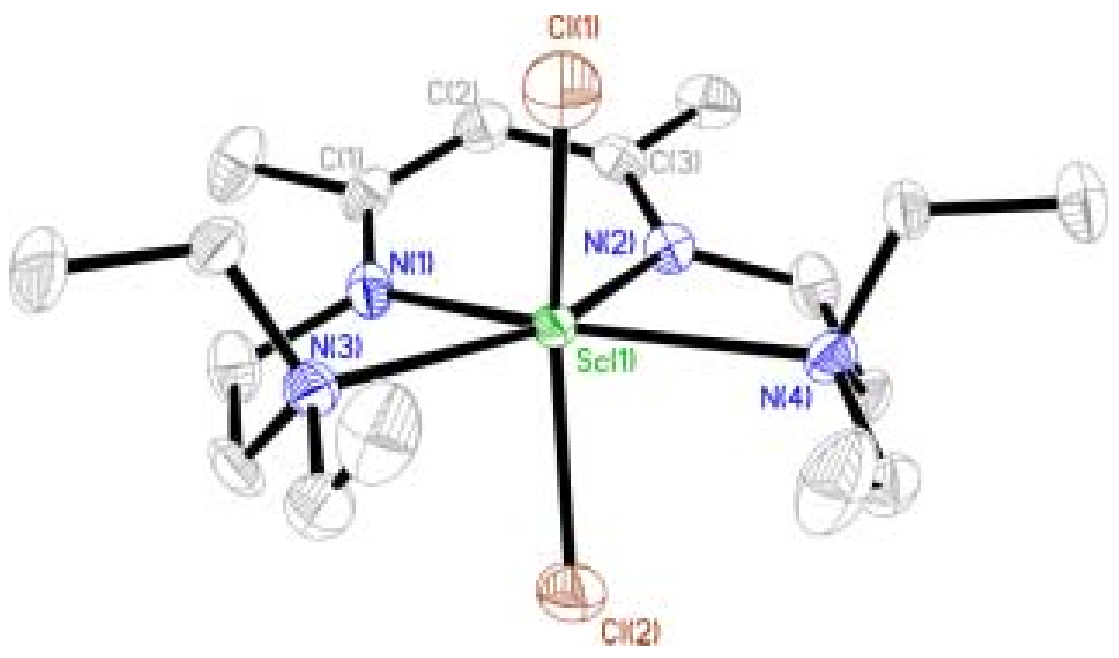

Figure 5: Molecular structure of 5b (50\% thermal ellipsoids probability, hydrogen atoms omitted for clarity).

In these compounds the coordination number of the metal ion is in each case six and the geometry around the metal atom is pseudooctahedral, both arms of the ligand are coordinated to the metal centre and all four nitrogen atoms and the metal atom are in the same plane. The Ln-N bond lengths are in the range of those for previously reported compounds. ${ }^{[63]}$ As far as the Ln-Br bond lengths are concerned, they are somewhat shorter than those found in literature as a consequence of both different coordination 
numbers and of different bond orders around the metal center. For instance the $\mathrm{Sc}-\mathrm{Br}$ bond length is $3.082(5) \AA$ in $\mathrm{Na}_{3} \mathrm{ScBr}_{6},{ }^{[63]}$ which is relatively long compared to that in 6 due to the greater steric hindrance at the scandium atom and of a Sc-Br formal bond order 0.5 in $\mathrm{Na}_{3} \mathrm{ScBr}_{6}$ even though the coordination number in both compounds for the scandium atoms is the same. The Ln-N bond lengths of the pendant arms are longer than those of the backbone due to the coordinative and covalent character involved in different bonding modes. The $\beta$-diketiminato ligands can act as either donors of 4 electrons, in this case the nature of the bonds is $\sigma$, or donors of 6 electrons, in this case the description of the bonds is $2 \sigma-\pi .^{[62,64]}$

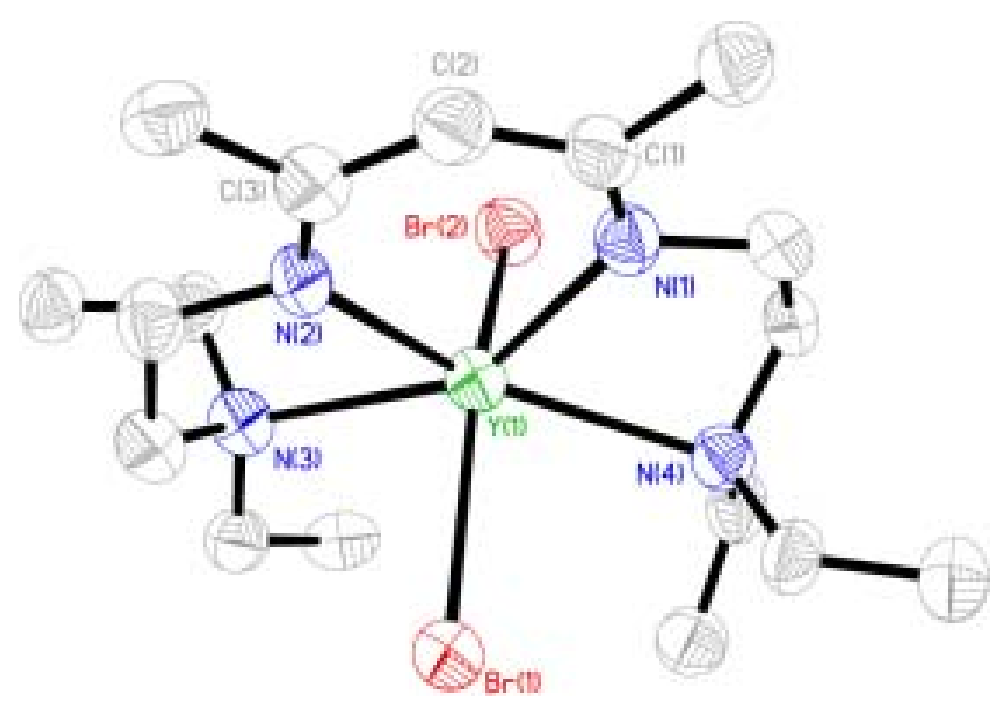

Figure 6: Molecular structure of $\mathbf{8}$ (50\% thermal ellipsoids probability, hydrogen atoms and toluene ommited for clarity).

Computational studies have shown that the bonding pattern between the ligand and metal ion can be deduced from the deviation of the metal ion from the $\mathrm{NC}_{3} \mathrm{~N}$ backbone plane. The bigger the distance to the plane, the higher is the $2 \sigma-\pi$ percent of the bonds. The insignificant distances for the compounds 6 and $\mathbf{8}(0.10 \AA$ and $0.07 \AA)$ verify a $2 \sigma$ bonding mode but the larger distances for both forms of 5 indicate that the bonds tend to be $2 \sigma-\pi(0.37 \AA$ and $0.69 \AA)$. For Sc and $\mathrm{Y}$ derivatives the ligand alone can accommodate the metal ions in the plane but the role of the halogen is not negligible. It has also been confirmed that the size of the substituents on the $\beta$-diketiminato frame can 
explain the deviation of the metal ion from the plane as well, ${ }^{[62]}$ but in complexes $\mathbf{5}, \mathbf{6}$, and $\mathbf{8}$ the methyl substituents are too small to be taken into account. Selected bond distances and angles for compounds 5, 6, and $\mathbf{8}$ are listed in Table 1.

Table 1 Selected bond lengths $(\AA)$ and angles $\left(^{\circ}\right)$ for the compounds $\mathbf{5}(\mathbf{a}, \mathbf{b}), \mathbf{6}$, and $\mathbf{8} \cdot \mathbf{C}_{7} \mathbf{H}_{8}$

\begin{tabular}{|c|c|c|c|c|}
\hline Bond lengths & $5 a$ & $5 \mathbf{b b}$ & 6 & $8 \cdot \mathrm{C}_{7} \mathrm{H}_{8}$ \\
\hline $\operatorname{Ln}(1)-\mathrm{N}(1)$ & $2.151(2)$ & $2.189(3)$ & $2.345(6)$ & $2.402(7)$ \\
\hline $\operatorname{Ln}(1)-\mathrm{N}(2)$ & $2.174(2)$ & $2.175(3)$ & $2.345(6)$ & $2.410(7)$ \\
\hline $\operatorname{Ln}(1)-\mathrm{N}(3)$ & $2.534(2)$ & $2.519(3)$ & $2.601(6)$ & $2.613(7)$ \\
\hline $\operatorname{Ln}(1)-\mathrm{N}(4)$ & $2.458(2)$ & $2.511(4)$ & $2.577(6)$ & $2.634(7)$ \\
\hline $\mathrm{Sc}(1)-\mathrm{Cl}(1)$ & $2.453(1)$ & $2.442(2)$ & & \\
\hline $\mathrm{Sc}(1)-\mathrm{Cl}(2)$ & $2.440(1)$ & $2.465(1)$ & & \\
\hline $\operatorname{Ln}(1)-\operatorname{Br}(1)$ & & & $2.751(1)$ & $2.807(1)$ \\
\hline $\operatorname{Ln}(1)-\operatorname{Br}(2)$ & & & $2.776(1)$ & $2.833(1)$ \\
\hline \multicolumn{5}{|l|}{ Angles } \\
\hline $\mathrm{N}(1)-\operatorname{Ln}(1)-\mathrm{N}(2)$ & $84.66(8)$ & $83.52(12)$ & $79.9(2)$ & $78.1(2)$ \\
\hline $\mathrm{N}(1)-\operatorname{Ln}(1)-\mathrm{N}(4)$ & $160.76(8)$ & $154.99(12)$ & $164.64(5)$ & $149.0(2)$ \\
\hline $\mathrm{N}(4)-\operatorname{Ln}(1)-\mathrm{N}(3)$ & $119.97(7)$ & $132.78(11)$ & $138.1(2)$ & $140.9(2)$ \\
\hline $\mathrm{N}(2)-\operatorname{Ln}(1)-\mathrm{N}(3)$ & 163.91(8) & $154.88(12)$ & $71.9(2)$ & $148.5(2)$ \\
\hline $\operatorname{Ln}(1)-\mathrm{N}(1)-\mathrm{C}(1)$ & $129.16(19)$ & $125.0(3)$ & $130.1(5)$ & $129.7(5)$ \\
\hline $\mathrm{N}(1)-\mathrm{C}(1)-\mathrm{C}(2)$ & $123.0(2)$ & $123.2(4)$ & $125.2(7)$ & $127.7(9)$ \\
\hline $\mathrm{C}(1)-\mathrm{C}(2)-\mathrm{C}(3)$ & $128.8(2)$ & $128.0(4)$ & $130.1(8)$ & $127.8(9)$ \\
\hline $\mathrm{C}(2)-\mathrm{C}(3)-\mathrm{N}(2)$ & 124.1(3) & $123.5(3)$ & $124.6(7)$ & $125.4(7)$ \\
\hline $\mathrm{C}(3)-\mathrm{N}(2)-\operatorname{Ln}(1)$ & $126.91(17)$ & $124.9(3)$ & $129.9(5)$ & $131.0(5)$ \\
\hline $\operatorname{Br}(1)-\operatorname{Ln}(1)-\operatorname{Br}(2)$ & & & $145.29(4)$ & $145.98(3)$ \\
\hline $\mathrm{Cl}(1)-\mathrm{Sc}(1)-\mathrm{Cl}(2)$ & 166.71(3). & $152.72(6)$ & & \\
\hline $\mathrm{N}(2)-\operatorname{Ln}-\mathrm{X}(1)$ & $95.12(6)$ & $97.49(10)$ & $90.40(4)$ & $94.78(16)$ \\
\hline$N(1)-\operatorname{Ln}-\mathrm{X}(1)$ & $95.88(6)$ & $102.28(9)$ & $93.42(4)$ & $111.20(16)$ \\
\hline $\mathrm{N}(4)-\operatorname{Ln}-\mathrm{X}(1)$ & $86.95(6)$ & $87.56(9)$ & $86.16(3)$ & $84.24(14)$ \\
\hline $\mathrm{N}(3)-\mathrm{Ln}-\mathrm{X}(1)$ & $86.53(5)$ & $85.19(9)$ & $90.75(4)$ & $82.04(14)$ \\
\hline
\end{tabular}

\subsubsection{Synthesis of $\operatorname{LScI}_{2}(10)$ and $\mathrm{LYI}_{2}(11)$}

The iodine derivatives can be considered also as valuable starting materials. In this direction, our group reported already two diiodo derivatives with the same ligand. ${ }^{[65]}$ Reaction between the potassium salt of the ligand and scandium and yttrium triiodide, 
respectively, in toluene at $120{ }^{\circ} \mathrm{C}$ yielded after extraction in dichloromethane and washing the crude products with pentane, the diiodo complexes in acceptable amounts. The potassium salt was obtained in situ from $\mathrm{LH}$ and in excess $\mathrm{KH}$ at elevated temperatures. These compounds were characterized by NMR spectrometry, EI-MS and elemental analysis. As expected for iodine complexes, the molecules are not stable under electron impact conditions and the spectra show fragments of the ligand and iodine. The resonances in ${ }^{45} \mathrm{Sc}$ NMR for the chloro, bromo and iododerivatives of scandium are shifted downfield in accordance to increasing shielding of scandium.

Table 2. Resonances of the ${ }^{45} \mathrm{Sc}$ NMR spectra (ppm) for the complexes $\mathbf{5}, \mathbf{6}$ and $\mathbf{1 0}$

\begin{tabular}{|lll|}
\hline $\mathbf{5}$ & $\mathbf{6}$ & $\mathbf{1 0}$ \\
\hline 286 & 335 & 392 \\
\hline
\end{tabular}

\subsection{The Adducts $\mathrm{LLaCl}_{2} \cdot \mathrm{LLi}(12)$ and $\mathrm{LCeCl}_{2} \cdot \mathrm{LLi}(13)$}

The complexes presented so far have as central atom scandium, yttrium and lutetium. Scandium is the smallest rare earth metal (See Figure 1). The coordination number 6 is common for Sc with no additional coordinating solvents. The situation changes gradually from scandium with increasing size in the rare earth elements row to lutetium to ytterbium, thulium, erbium, and holmium (with the same ionic radius as yttrium). Aside from the complexes 5 - 11 compounds of $\mathrm{Yb}, \mathrm{Ho}, \mathrm{Tb}, \mathrm{Eu}, \mathrm{Sm}$, and $\mathrm{Pr}$ with the same ligand solvent- and salt free have been synthesized by Roesky et al. ${ }^{[32,65-67]}$ The next quest was to react the ligand with the largest lanthanides, La and Ce.

The lithium salt reacted with $\mathrm{LaCl}_{3}$ and $\mathrm{CeCl}_{3}$ in refluxing toluene to yield the adducts $\mathrm{LLaCl}_{2} \cdot \mathrm{LLi}(12)$ and $\mathrm{LCeCl}_{2} \cdot \mathrm{LLi}(13)$, respectively, in small yields (ca. $30 \%$ based on the amount of lithium salt employed). These compounds are very soluble in, THF, and dichloromethane, probably due to the coordinated lithium salt, less in toluene, and they can be recrystallized from hexane with a few drops of toluene. The crystals are indefinitely stable in solution but they decompose upon drying becoming oily after removing the solvent. After decomposition, the resulting material cannot be completely redissolved in $\mathrm{C}_{6} \mathrm{D}_{6}$ or $\mathrm{CHCl}_{3}$ and the NMR shows only the peaks characteristic of the lithium salt. In the EI-MS the $\mathrm{LLaCl}_{2}$ and $\mathrm{LCeCl}_{2}$ fragments and fragments of the ligand 
can be observed $\left(m / z 504\left(\mathrm{LLaCl}_{2}\right), 505\left(\mathrm{LCeCl}_{2}\right)\right.$, and $\left.302(\mathrm{LLi})\right)$. In ${ }^{7} \mathrm{Li}$ NMR spectrum of 12 the resonance is shifted up field in comparison to the uncoordinated lithium salt (from 1.79 to $0.61 \mathrm{ppm}$ ). ${ }^{[67]}$ Crystals of $\mathbf{1 3}$ are more sensitive than that of $\mathbf{1 2}$ decaying during attempts to dry them under slightly reduced pressure.

Compound 12 is the first $\beta$-diketiminato complex with lanthanum. Two $\beta$ diketiminato complexes of cerium were reported by Lappert et al. ${ }^{[68]}$ but the chloride compound is surrounded by two $\beta$-diketiminato groups in its need for coordinative saturation.

\subsubsection{X-ray Structural Analyses of Compounds 12 and 13}

Both compounds are isostructural and crystallize in the monoclinic space group $P 2_{1} / n$ with only slight differences of their bond parameters. The molecules present multiple disorders in the alkyl regions of the ligand arms. Figure 7 shows the molecular structure of 12 without the respective disorders. The coordination numbers of the lanthanoid atoms are 10, normal for these elements. The ligand arms are not anymore both coordinated to the metal as in the above-described complexes. This is an example where the "arm-on, arm-off" function of the ligand is effective. Unlike the other reported cerium complex with chlorine and a $\beta$-diketiminato ligand, the backbone is almost planar and the deviation of $\mathrm{La}$ and $\mathrm{Ce}$ from the $\mathrm{NC}_{3} \mathrm{~N}$ plane point to a $2 \sigma-\pi$ interaction (1.387(1) $\AA)$. For the La compound the corresponding distance is 1.395(1) $\AA$. The distances for $\mathrm{Ce}-\mathrm{N}(1)$ and $\mathrm{Ce}-\mathrm{N}(2)$ are slightly longer than those reported in the literature probably due to missing puckering. ${ }^{[68]}$

The lithium salt coordinates in a Cp like mode satisfying the need of La and Ce for high coordination numbers. Distances from the metal to the centroids of the ligand frame are 2.47(4) $\AA$ (for 12) and 2.44(5) $\AA$ (for 13), slightly shorter than the respective distances in $\mathrm{Cp}_{3} \mathrm{La}^{[69]}$ and in $\mathrm{Cp}_{3} \mathrm{Ce}^{[70]}$, and average distances from the metal to all atoms belonging to the backbone $(\mathrm{C}(18), \mathrm{C}(19), \mathrm{C}(20), \mathrm{N}(5), \mathrm{N}(6))$ are 2.81(4) $\AA$ (12) and 2.76(5) $\AA$ (13), respectively, are remarkably close to the corresponding distances in $\mathrm{Cp}_{3} \mathrm{La}$ and in $\mathrm{Cp}_{3} \mathrm{Ce}(2.82(4) \AA$ and $2.75(5) \AA)$. 


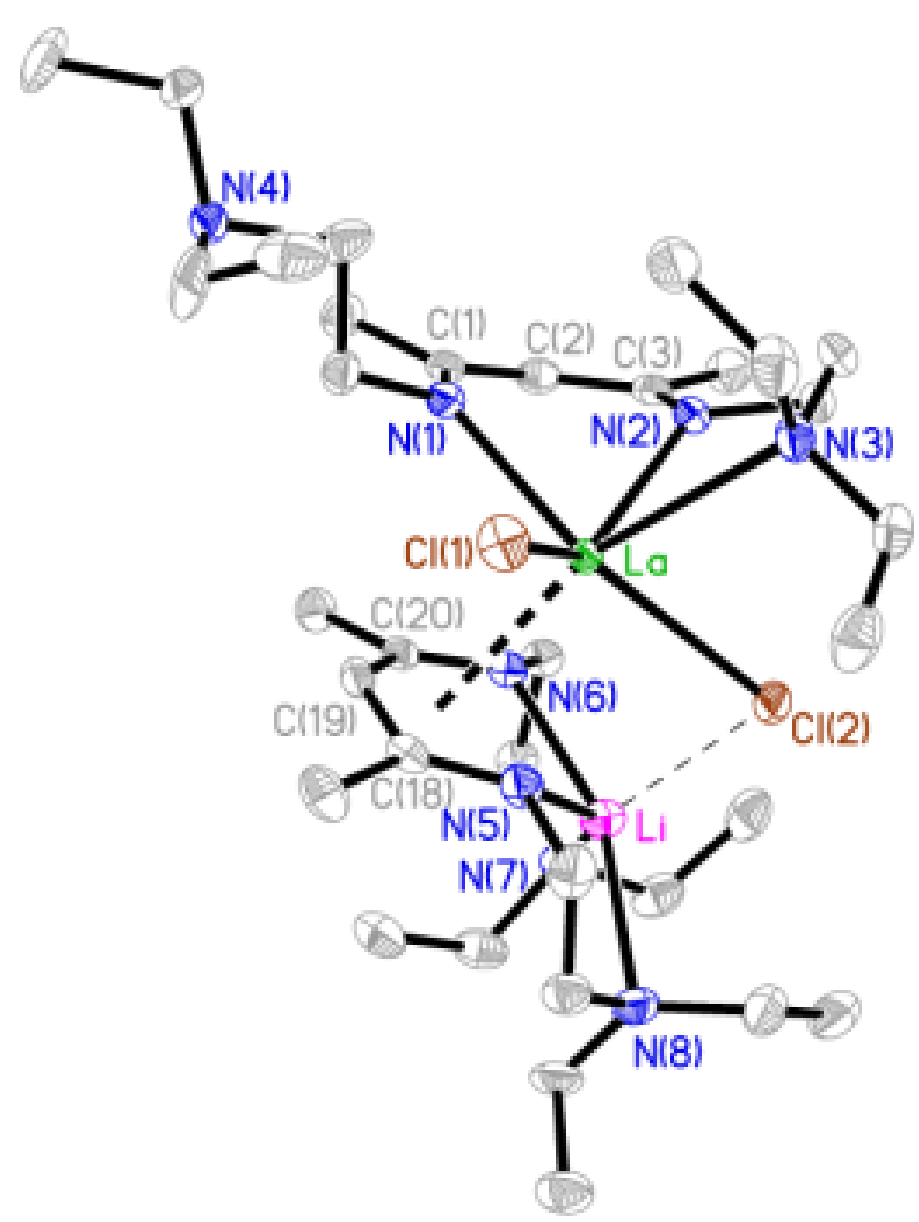

Figure 7: Molecular structure of $\mathbf{1 2}$ (50\% thermal ellipsoids probability, hydrogen atoms ommited for clarity).

Interestingly, the angles between the two $\beta$-diketiminato frames are only $15^{\circ}$ for 12 and $14^{\circ}$ for 13 , the two accommodating one with each other in "antiperiplanar" conformations. The bond lengths within the coordinated lithium salt exhibit no significant changes in comparison to the monomeric, uncoordinated, lithium salt. ${ }^{[0]}$ In contrast position of lithium atom with respect to the ligand backbone is expanded from $0.07 \AA$ in the free salt to 0.83(4) $\AA$ (12) and 0.82(5) $\AA$ (13), respectively, as a consequence of establishing an interaction with the chlorine atom and the bridge formation. The same reason implies also the change in the angles between the ligand backbone and the plane of the four nitrogen atoms $\mathrm{N}(5), \mathrm{N}(6), \mathrm{N}(7), \mathrm{N}(8)$ (from $10^{\circ}$ to $37^{\circ}$ ). 
Table 3 Selected bond lengths $(\AA)$ and angles $\left(^{\circ}\right)$ for the compounds $\mathbf{1 2}$ and $\mathbf{1 3}$

\begin{tabular}{|llllcc|}
\hline Bond lengths & $\mathbf{1 2}$ & $\mathbf{1 3}$ & Angles & $\mathbf{1 2}$ & $\mathbf{1 3}$ \\
\hline Ln-N(1) & $2.537(2)$ & $2.524(2)$ & $\mathrm{N}(1)-\mathrm{Ln}-\mathrm{N}(2)$ & $70.98(6)$ & $71.45(6)$ \\
Ln-N(2) & $2.507(2)$ & $2.485(2)$ & $\mathrm{C}(1)-\mathrm{C}(2)-\mathrm{C}(3)$ & $128.4(2)$ & $128.5(2)$ \\
$\mathrm{Ln}-\mathrm{N}(3)$ & $2.929(2)$ & $2.932(2)$ & $\mathrm{Cl}(1)-\mathrm{Ln}-\mathrm{Cl}(2)$ & $125.137(19)$ & $124.495(19)$ \\
Ln-Cl(1) & $2.792(1)$ & $2.774(1)$ & $\mathrm{N}(5)-\mathrm{Li}-\mathrm{N}(6)$ & $82.17(15)$ & $81.85(16)$ \\
Ln-Cl(2) & $2.905(1)$ & $2.885(1)$ & $\mathrm{C}(18)-\mathrm{C}(19)-\mathrm{C}(20)$ & $127.9(2)$ & $127.6(2)$ \\
La-C(18) & $3.021(2)$ & $2.999(2)$ & $\mathrm{Li}-\mathrm{Cl}(2)-\mathrm{Ln}$ & $77.77(9)$ & $77.65(10)$ \\
La-C(19) & $2.958(2)$ & $2.947(2)$ & $\mathrm{N}(5)-\mathrm{Li}-\mathrm{N}(6)$ & $82.17(15)$ & $81.85(16)$ \\
La-C(20) & $2.973(2)$ & $2.948(2)$ & $\mathrm{N}(6)-\mathrm{Li}-\mathrm{N}(7)$ & $80.35(15)$ & $80.54(14)$ \\
La-N(5) & $2.714(2)$ & $2.682(2)$ & $\mathrm{N}(7)-\mathrm{Li}-\mathrm{N}(8)$ & $105.83(17)$ & $106.12(18)$ \\
La-N(6) & $2.605(2)$ & $2.571(2)$ & $\mathrm{N}(5)-\mathrm{Li}-\mathrm{N}(8)$ & $80.46(15)$ & $80.65(15)$ \\
La-Li & $3.368(4)$ & $3.346(4)$ & $\mathrm{N}(1)-\mathrm{C}(1)-\mathrm{C}(2)$ & $123.6(2)$ & $123.8(2)$ \\
Li-N(5) & $2.153(4)$ & $2.150(5)$ & $\mathrm{N}(2)-\mathrm{C}(3)-\mathrm{C}(2)$ & $123.18(19)$ & $122.8(2)$ \\
Li-N(6) & $2.173(4)$ & $2.182(4)$ & $\mathrm{N}(5)-\mathrm{C}(18)-\mathrm{C}(19)$ & $121.46(19)$ & $121.4(2)$ \\
$\mathrm{Cl}(2)-\mathrm{Li}$ & $2.427(4)$ & $2.421(5)$ & $\mathrm{N}(6)-\mathrm{C}(20)-\mathrm{C}(19)$ & $120.78(19)$ & $121.07(19)$ \\
\hline
\end{tabular}

\subsection{Reactivity of $\mathrm{LScX}_{2}\left(\mathrm{X}=\mathrm{Cl}\right.$, Br) and $\mathrm{LYCl}_{2}$}

Only little is known about the reactivity of compounds of the type $\operatorname{LLnX}_{2}(\mathrm{~L}=$ $\mathrm{Cp}, \mathrm{Cp}$ derivative, or other monoanionic spectator ligands, $\mathrm{Ln}=$ rare earth metal, $\mathrm{X}=$ halogenide) partly because of the extreme reactivity of the products that can easily undergo redistribution and elimination reactions, and because of their high sensitivity to water and oxygen. Half-sandwich complexes with $\mathrm{Cp}$ ligands have recently been reviewed by Okuda et al. ${ }^{[26]}$ Hessen et al. investigated yttrium alkyl and benzyl complexes with ancillary amino-amidinate ligands: $\left[\left({ }^{t} \mathrm{BuC}\left(\mathrm{N}^{i} \mathrm{Pr}\right)_{2}\right]^{-}\right.$and $\left[\mathrm{PhC}\left(\mathrm{NSiMe}_{3}\right) \mathrm{N}\left(\mathrm{CH}_{2}\right) \mathrm{NMe}_{2}\right]^{-}(\mathrm{n}=2,3) .{ }^{[57]}$, and Shen et al. synthesized a series of mixed ligand ytterbium complexes. ${ }^{[31]}$ The by now best studied compounds are those of scandium with $\beta$-diketiminato ligands by Piers and co-workers (Scheme 2). ${ }^{\text {[47c,62] }}$

With the ligand used in this study $\mathrm{LTb}\left(\mathrm{CH}_{2} \mathrm{SiMe}_{3}\right)_{2}$ was synthesized. ${ }^{[66]}$ 


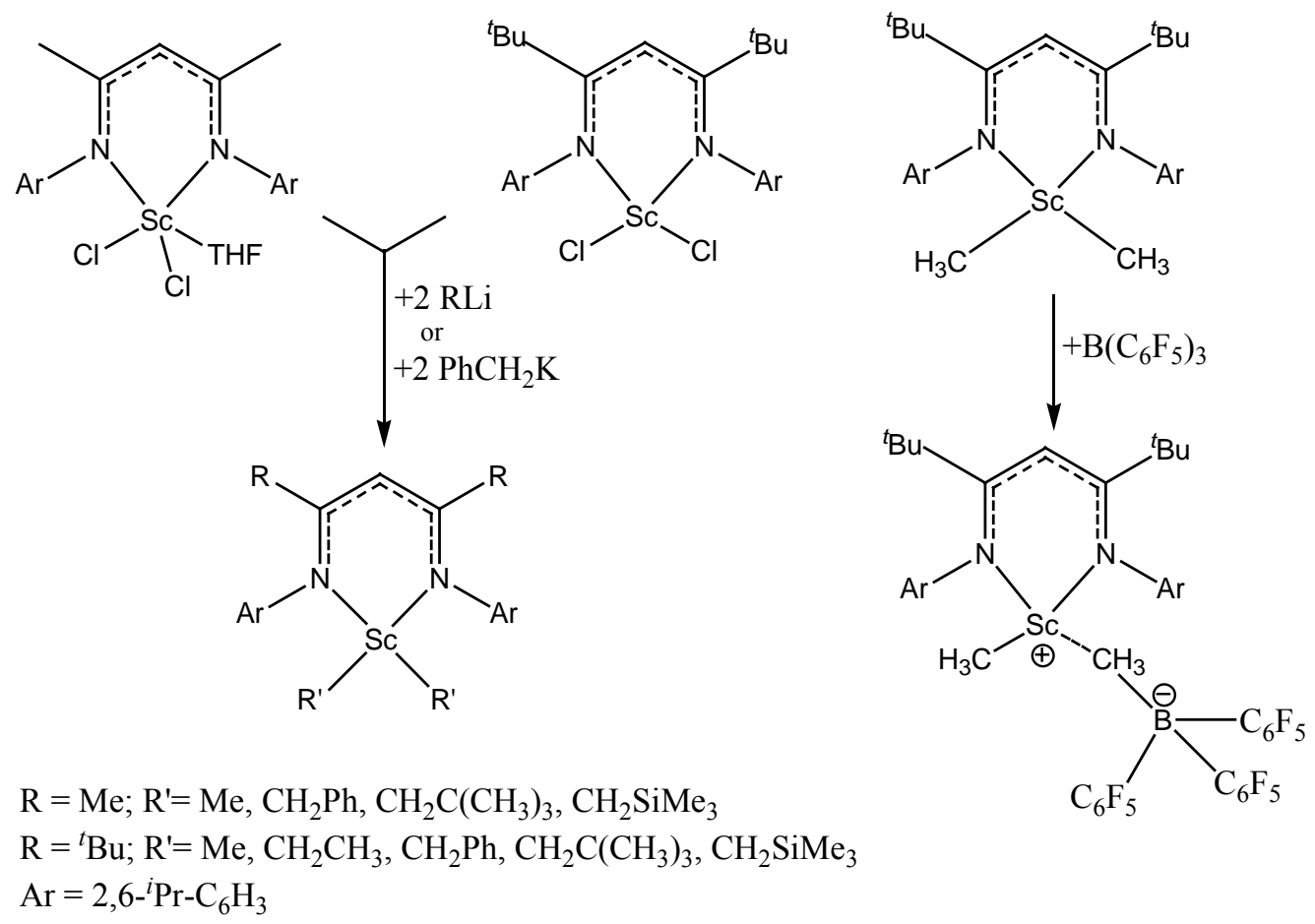

Scheme 2

\subsubsection{Synthesis of $\left[(\mathrm{L}-\mathrm{H}) \mathrm{ScCH}_{2} \mathrm{~N}\left(\mathrm{SiMe}_{3}\right)_{2}\right]_{2}(14)$}

Due to their ability to take part in various catalytic processes involving $\mathrm{C}-\mathrm{H}$ bond activation, the organo complexes of the early transition metals and lanthanides have been actively investigated over the past decade. ${ }^{[51 \mathrm{a}, 58,71]}$

Unlike the scandium compounds studied by Piers et al., $\mathrm{LScCl}_{2}$ (5) is quite resistant to metathesis reactions using alkyllithium reagents but reacts with $\mathrm{NaN}\left(\mathrm{SiMe}_{3}\right)_{2}$ in a 1:2 molar ratio in toluene at room temperature for 1d.The result is a dimeric compound 14 with two scandium ring systems connected by two methylene bridges (Equation 2). ${ }^{[20]}$

$$
\begin{aligned}
& 2 \mathrm{C}_{17} \mathrm{H}_{35} \mathrm{~N}_{4} \mathrm{ScCl}_{2}+4 \mathrm{NaN}\left(\mathrm{SiMe}_{3}\right)_{2} \underset{-2 \mathrm{NaCl}}{\stackrel{\text { toluene }}{\longrightarrow}}\left[\mathrm{C}_{17} \mathrm{H}_{35} \mathrm{~N}_{4} \mathrm{ScN}\left(\mathrm{SiMe}_{3}\right)_{2}\right]_{2} \\
& 5 \\
& -2 \mathrm{HN}\left(\mathrm{SiMe}_{3}\right)_{2}
\end{aligned}
$$

Equation 2

For the formation of compound $\mathbf{1 4}$, a multistep mechanism can be proposed. The first step is the monosubstitution (A) of one of the chlorine atoms in $\mathbf{5}$ followed by $\mathrm{C}-\mathrm{H}$ 
bond-breaking and a dimerization step. This assumption can be regarded as a result of both the high nucleophilicity of $\left(\mathrm{Me}_{3} \mathrm{Si}\right)_{2} \mathrm{~N}^{-}$and the strong electrophilicity of scandium. Indeed, the $\beta$-diketiminato ligand possesses hydrogen atoms of low electron density on the methyl groups by virtue of the localized bond resonance form $\mathbf{B}$ (see Scheme 3).

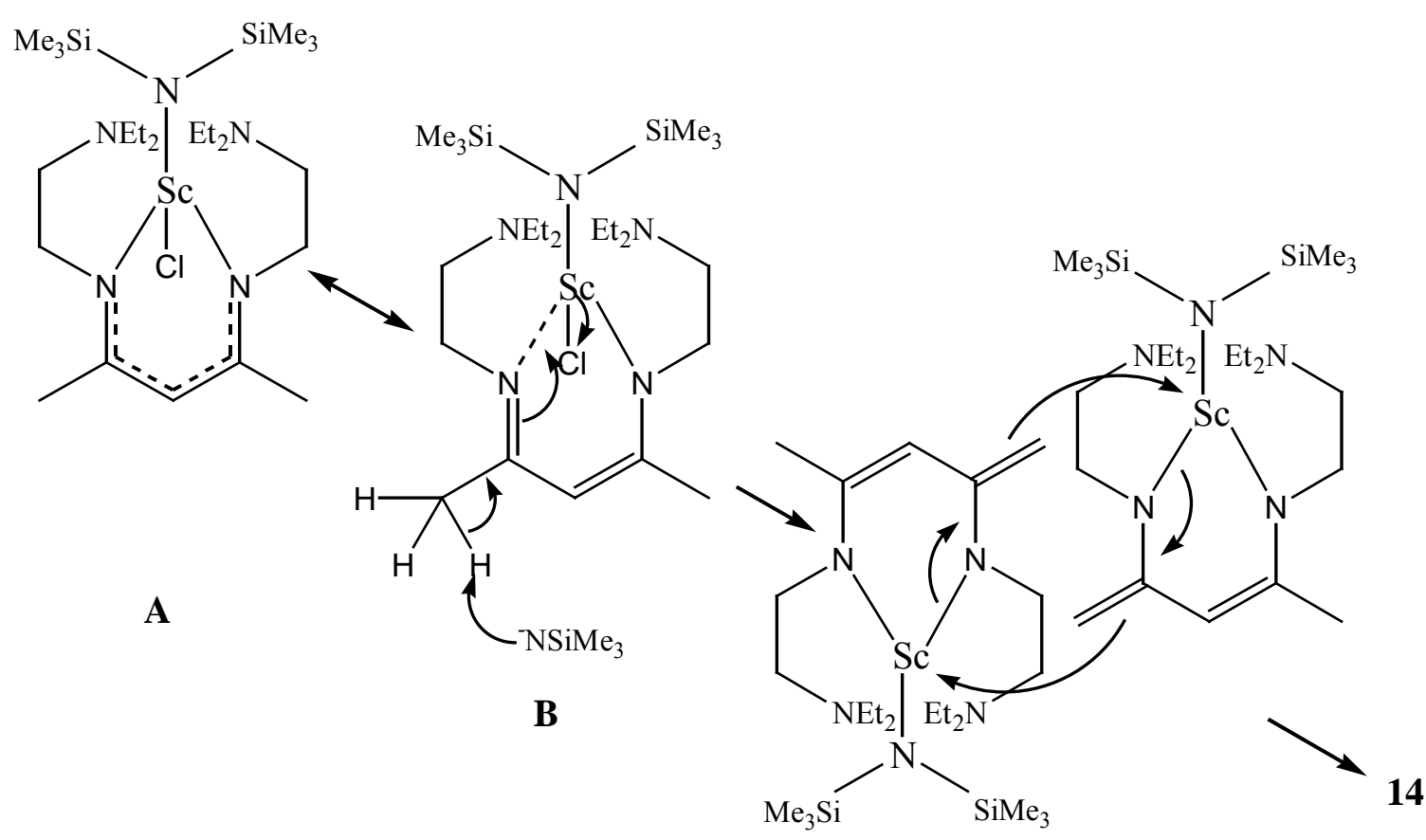

Scheme 3

Nevertheless, the $\mathrm{C}-\mathrm{H}$ bonds are even more polarized by the withdrawing effect of scandium and the highly hindered base $\left(\left(\mathrm{Me}_{3} \mathrm{Si}_{2} \mathrm{~N}^{-}\right)\right.$can easily deprotonate the ketiminato fragment to form a scandium "enolate" then undergoes subsequent dimerization. Monitoring the reaction on the NMR time scale was not successful, due to the rapid formation of 14. Reaction of $\mathrm{LScCl}_{2}$ with $\mathrm{NaN}\left(\mathrm{SiMe}_{3}\right)_{2}$ in a 1:1 molar ratio, using the same procedure as for $\mathbf{1 4}$, led to formation of a yellow substance whose MS spectrum exhibits a signal at $\mathrm{m} / \mathrm{z}$ 520, which could be assigned to $\left[\mathrm{LScClN}\left(\mathrm{SiMe}_{3}\right)\left(\mathrm{SiMe}_{2}\right)\right]^{+}$. This finding supports the proposed reaction pathway.

An alternative mechanism implies, after monosubstitution of one of the chlorine atoms in 5, the $\mathrm{C}-\mathrm{H}$ bond-breaking step, which takes place in a concerted mode (Scheme 4). However, the reaction is clearly a $\mathrm{C}-\mathrm{H}$ activation process. 


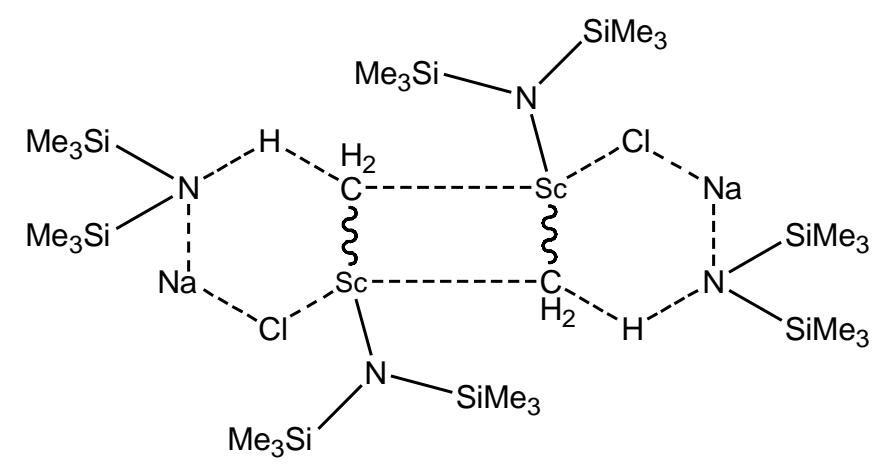

Scheme 4

\subsubsection{X-ray Structural Analysis of 14 and NMR Discussion}

The X-ray single-crystal structural analysis shows that $\mathbf{1 4}$ is a dimer that crystallizes in the monoclinic space group $P 2_{1} / c$ with two toluene molecules retained in the asymmetric unit. The Sc atoms in $\mathbf{1 4}$ are pentacoordinated with a distorted-trigonalbipyramidal geometry, where $\mathrm{N}(4)$ and $\mathrm{N}(2), \mathrm{N}(9)$ and $\mathrm{N}(7)$, respectively, are arranged in approximately apical positions (Figure 8). The toluene molecules can be partially removed when compound $\mathbf{1 4}$ is subjected to vacuum. This is confirmed by the elemental analysis and the NMR spectra. One of the characteristics of $\mathbf{1 4}$ is the unique arrangement of the scandium atoms, which are each part of three cycles: an eight-membered ring in a chair conformation, an six-membered ring, and an five-membered ring. The thermodynamically favored formation of $\mathbf{1 4}$ and the conservation of its structure in solution are indicated by the NMR spectrum in toluene. In the temperature range 300 $373 \mathrm{~K}$ no changes of the resonance signals is observable. The Sc-C(bridge) bond lengths are typical of those in other organoscandium complexes. ${ }^{[20,30,51 \mathrm{a}, 62,72]}$ The $\mathrm{Sc}-\mathrm{N}\left(\mathrm{SiMe}_{3}\right)_{2}$ distance is greater than those in the tricoordinated $\mathrm{Sc}\left(\mathrm{N}\left(\mathrm{SiMe}_{3}\right)_{2}\right)_{3}{ }^{[73]}$ but is equal to the $\mathrm{Sc}-\mathrm{N}(\beta$-diketiminato $)$ bond lengths of 14 . The ligand $\mathrm{L}$ is unsymmetrically coordinated toward Sc, with one dangling $\mathrm{NEt}_{2}$ group in the solid state as well as in solution. Table 4 presents selected bond lengths and angles for this compound. The ${ }^{1} \mathrm{H}$ NMR spectrum of 14 exhibits eight resonances (in the $2.4-4.15$ ppm region) whose overall intensities render the anticipated number of hydrogen atoms for the methylene groups, except those of the bridges, which cannot be assigned due to multiple interactions even after 2DCOSY experiments. Moreover, the molecular asymmetry allows for observation of two 
different resonances in the ${ }^{1} \mathrm{H}$ NMR spectrum of the bridging methylene groups; in the ${ }^{29} \mathrm{Si}$ NMR spectrum two resonances for silicon atoms are observed. The Sc resonance in the NMR spectrum is shifted upfield in comparison with $\mathbf{5}$ (423.6 to $286.2 \mathrm{ppm}$ ) as a result of a lower coordination number and higher electron density at Sc in $\mathbf{1 4}$.
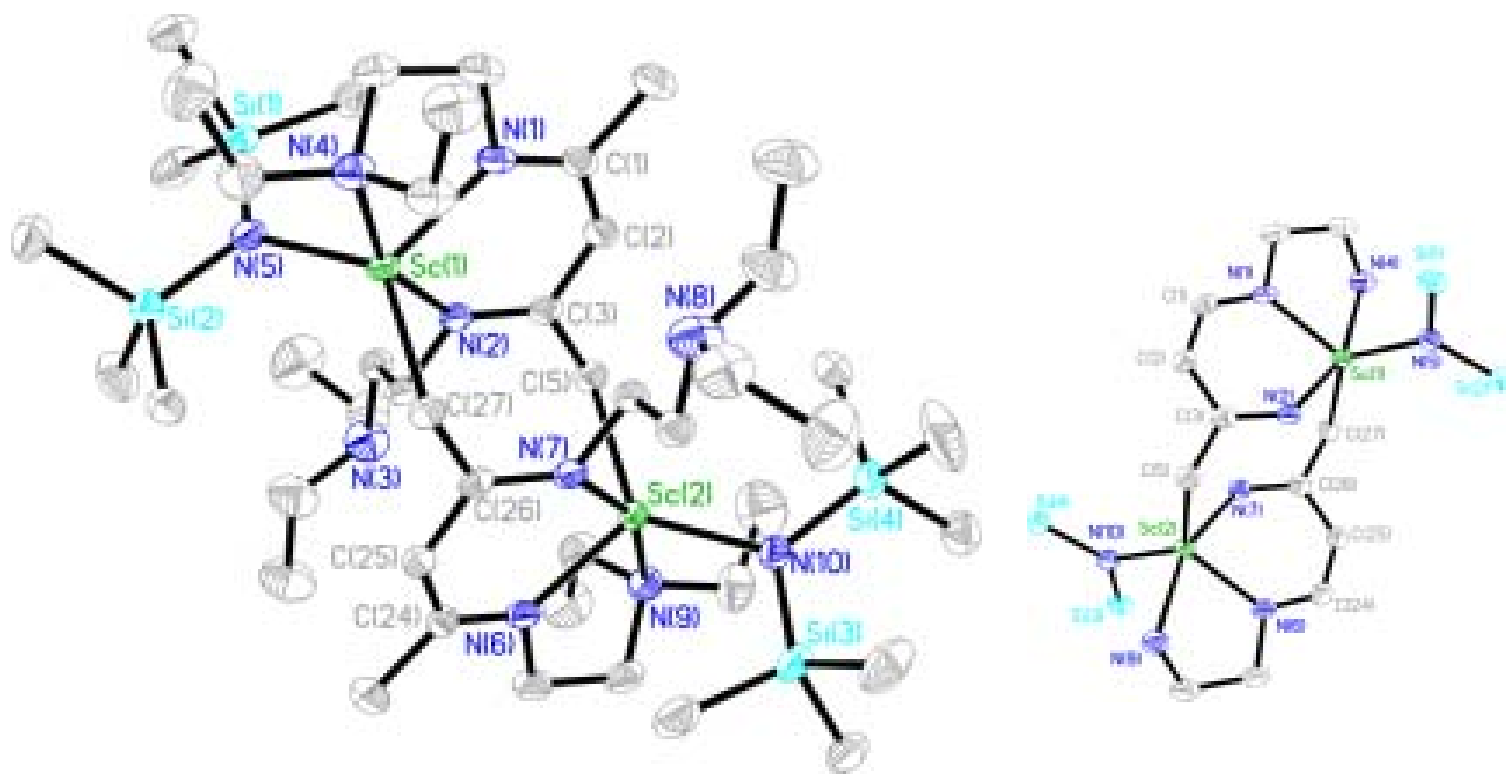

Figure 8: Molecular Structure of 14 (50\% thermal ellipsoids probability, hydrogen atoms ommited for clarity)(left); Core of $\mathbf{1 4}$ (right).

Table 4. Selected bond lengths $(\AA)$ and angles $\left(^{\circ}\right)$ for the compound 14

\begin{tabular}{|llllll|}
\hline Bond lengths & & & Angles \\
\hline $\mathrm{Sc}(1)-\mathrm{N}(2)$ & $212.1(2)$ & $\mathrm{Sc}(2)-\mathrm{N}(9)$ & $246.3(2)$ & $\mathrm{N}(2)-\mathrm{Sc}(1)-\mathrm{N}(1)$ & $84.35(7)$ \\
$\mathrm{Sc}(1)-\mathrm{N}(5)$ & $212.4(2)$ & $\mathrm{Sc}(1)-\mathrm{C}(27)$ & $239.7(2)$ & $\mathrm{N}(7)-\mathrm{Sc}(2)-\mathrm{N}(6)$ & $83.89(7)$ \\
$\mathrm{Sc}(1)-\mathrm{N}(1)$ & $213.0(2)$ & $\mathrm{Sc}(2)-\mathrm{C}(5)$ & $238.1(2)$ & $\mathrm{C}(1)-\mathrm{C}(2)-\mathrm{C}(3)$ & $128.9(2)$ \\
$\mathrm{Sc}(1)-\mathrm{N}(4)$ & $246.8(2)$ & $\mathrm{C}(26)-\mathrm{C}(27)$ & $144.6(3)$ & $\mathrm{C}(3)-\mathrm{C}(5)-\mathrm{Sc}(2)$ & $113.02(14)$ \\
$\mathrm{Sc}(2)-\mathrm{N}(7)$ & $211.8(2)$ & $\mathrm{C}(3)-\mathrm{C}(5)$ & $145.0(3)$ & $\mathrm{C}(24)-\mathrm{C}(25)-\mathrm{C}(26)$ & $129.0(2)$ \\
$\mathrm{Sc}(2)-\mathrm{N}(10)$ & $213.1(2)$ & $\mathrm{C}(1)-\mathrm{C}(2)$ & $138.0(3)$ & $\mathrm{C}(26)-\mathrm{C}(27)-\mathrm{Sc}(1)$ & $111.53(14)$ \\
$\mathrm{Sc}(2)-\mathrm{N}(6)$ & $213.9(2)$ & $\mathrm{C}(2)-\mathrm{C}(3)$ & $144.0(3)$ & & \\
\hline
\end{tabular}

This kind of behavior is imposed most probably by scandium and does not depend on the nature of the halogen involved because also the dibromo derivative $\mathrm{LScBr}_{2}$ (6) gives the same product under the same reaction conditions. 


\subsubsection{Synthesis of $\mathrm{LSc}\left(\mathrm{SO}_{3} \mathrm{CF}_{3}\right)_{2}(15)$}

As mentioned before, metathesis reactions of dihalogeno derivatives of the rare earth metals proceed with difficulty. Therefore the use of the electron withdrawing triflate $^{[23]}$ as a substituent on the scandium seemed to be a good option. ${ }^{[74]}$

Reaction of the dibromo derivate $\mathrm{LScBr}_{2}(6)$ with $\mathrm{AgSO}_{3} \mathrm{CF}_{3}$ occurs as expected with substitution of both bromine atoms due to the oxophilic character of scandium and the thermodynamically favored formation of $\mathrm{AgBr}$ (Equation 3).

$$
\mathrm{LScBr}_{2}+2 \mathrm{Ag}\left(\mathrm{SO}_{3} \mathrm{CF}_{3}\right)_{2} \longrightarrow \mathrm{LSc}\left(\mathrm{SO}_{3} \mathrm{CF}_{3}\right)_{2}+2 \mathrm{AgBr}
$$

6 15 Equation 3

Complex $\mathbf{1 5}$ is a yellow solid, very soluble in aromatic solvents, ether and THF. Although the Lewis acidity is decreased in comparison to $\mathrm{Sc}\left(\mathrm{SO}_{3} \mathrm{CF}_{3}\right)_{3}{ }^{[75]}$ as a consequence of the substitution of one triflate ligand by the nitrogen containing ligand $\mathrm{L}$, this compound can be advantageous in catalysis due to its high solubility in organic

solvents. ${ }^{[75-77]}$ Moreover, the two triflate ligands increase the electronic density on the scandium atom in $\mathbf{1 5}$ in comparison to $\mathbf{6}$, documented by the substantial upfield shift of the scandium resonance in the ${ }^{45} \mathrm{Sc}$ NMR spectrum (335.8 ppm in $\mathbf{6}$ to $185.0 \mathrm{ppm}$ in $\mathbf{1 5}$ ).

The dichloro derivate $\mathrm{LScCl}_{2}(5)$ reacts similarly with $\mathrm{AgSO}_{3} \mathrm{CF}_{3}$ with formation of the same product 15 and $\mathrm{AgCl}$ (Equation 4).

$$
\mathrm{LScCl}_{2}+2 \mathrm{Ag}\left(\mathrm{SO}_{3} \mathrm{CF}_{3}\right)_{2} \longrightarrow \mathrm{LSc}\left(\mathrm{SO}_{3} \mathrm{CF}_{3}\right)_{2}+2 \mathrm{AgCl}
$$

5

Equation 4
15

\subsubsection{X-ray Structural Analysis of 15}

Crystals suitable for the X-ray analysis were obtained over several days at $-26^{\circ} \mathrm{C}$. Compound 15 crystallizes in the orthorhombic space group Pnma. The crystal structure analysis (Figure 9) reveals that the scandium atom in $\mathbf{1 5}$ is hexacoordinated with a pseudooctahedral geometry and the triflate ligands are arranged in trans positions $(\mathrm{O}(3)$ $\mathrm{Sc}-\mathrm{O}(1) 170.9^{\circ}$ compared to $\mathrm{Br}(1)-\mathrm{Sc}(1)-\mathrm{Br}(2) 172.3^{\circ}$ in $\left.\mathbf{6}\right)$. 


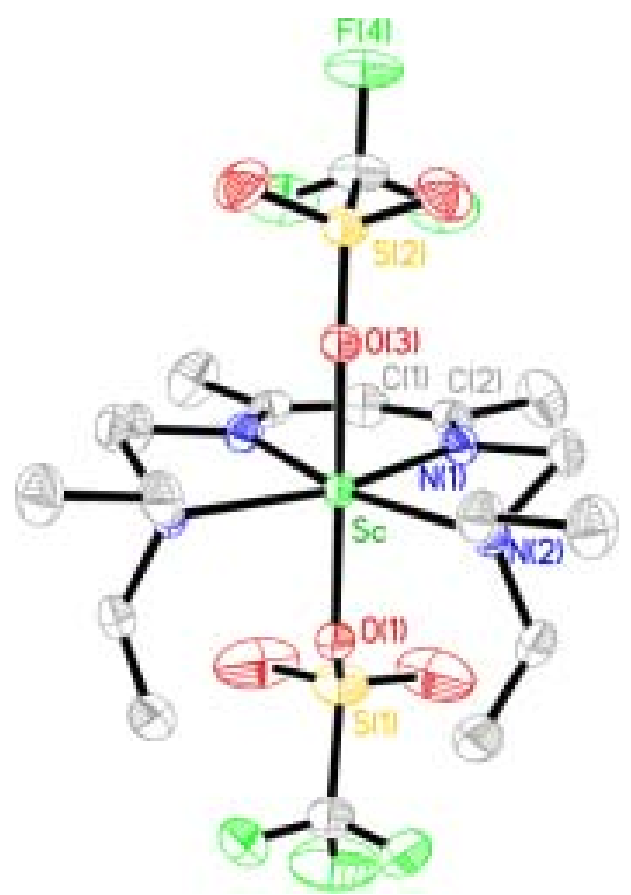

Figure 9: Molecular structure of 15 (50 \% thermal ellipsoids probability, hydrogen atoms ommited for clarity).

Table 5. Selected bond lengths $(\AA)$ and angles $\left(^{\circ}\right)$ for $\mathbf{1 5}$ (Symmetry transformations used to generate equivalent atoms $\# 1 \mathrm{x},-\mathrm{y}+1 / 2, \mathrm{z})$

\begin{tabular}{|llll|}
\hline Bond lengths & \multicolumn{3}{l|}{ Angles } \\
\hline $\mathrm{C}(1)-\mathrm{C}(2)$ & $1.393(2)$ & $\mathrm{O}(1)-\mathrm{Sc}-\mathrm{O}(3)$ & $170.88(7)$ \\
$\mathrm{N}(1)-\mathrm{Sc}$ & $2.126(2)$ & $\mathrm{N}(1)-\mathrm{Sc}-\mathrm{N}(1) \# 1$ & $85.38(8)$ \\
$\mathrm{N}(2)-\mathrm{Sc}$ & $2.378(1)$ & $\mathrm{N}(1)-\mathrm{Sc}-\mathrm{N}(2)$ & $79.66(5)$ \\
$\mathrm{O}(1)-\mathrm{Sc}$ & $2.126(2)$ & $\mathrm{N}(2)-\mathrm{Sc}-\mathrm{N}(2) \# 1$ & $115.12(7)$ \\
$\mathrm{O}(3)-\mathrm{Sc}$ & $2.108(2)$ & & \\
\hline
\end{tabular}

For steric reasons the triflate groups are not coordinated to scandium in a chelating fashion, they bind rather monodentate through one oxygen atom only. ${ }^{[7,79]}$. The NCCCN atoms of the $\beta$-diketiminato backbone as well as the nitrogen atoms of the ligand arms are almost coplanar. The deviation of scandium from this plane $(0.28 \AA)$ indicates a $\sigma$ bond interaction between scandium and the $\beta$-diketiminato ligand (in the $\mathrm{LScBr}_{2}(\mathbf{6})$ case the same distance is $\left.0.478(2) \AA\right) .{ }^{[61]}$ 


\subsubsection{Synthesis of $\left(\mathrm{Me}_{3} \mathrm{CISn}-\mu-\mathrm{F}\right)_{2} \mathrm{LSc}(16)$ and $\left(\mathrm{Me}_{3} \mathrm{BrSn}-\mu-\mathrm{F}\right)_{2} \mathrm{LSc}(17 \mathrm{a}, 17 \mathrm{~b})$}

On the basis of the HSAB principle, ${ }^{[23]}$ it is expected that rare earths to form very stable compounds with fluorine. ${ }^{[80 \mathrm{a}, 80 \mathrm{~b}]}$ These compounds have a distinct importance due to their extremely low solubility. ${ }^{[23]}$ This is the reason for which the organofluorides of the rare earths cannot be obtained by simple metathesis reactions like the corresponding chloride derivatives. Attempts to make a systematic study on organolanthanide fluorides was undertaken in Mak's group ${ }^{[80 \mathrm{c}]}$ but they are much less explored than their congeners of the group $4 .^{[81-83]}$

Using $\mathrm{Me}_{3} \mathrm{SnF}$ as fluorinating reagent for 5 and $\mathbf{6}$ led to compounds $\mathbf{1 6}$ and 17, respectively, which comprise the anticipated difluorinated scandium derivatives, but bridged by fluorine to two $\mathrm{Me}_{3} \mathrm{SnCl}$ (or $\mathrm{Me}_{3} \mathrm{SnBr}$ ) molecules.

$$
\mathrm{LScBr}_{2}+2 \mathrm{Me}_{3} \mathrm{SnF} \longrightarrow\left(\mathrm{Me}_{3} \mathrm{BrSn}-\mu-\mathrm{F}\right)_{2} \mathrm{LSc}
$$

6

Equation 5

The crystals of $\mathbf{1 6}$ and $\mathbf{1 7}$ are extremely sensitive, once the mother liquor is removed; they lose in minute time their solid feature. Since the substances cannot be redissolved in toluene or any other solvent, this is indicating that most likely decomposition and formation of insoluble fluorides has occurred. Since compound $\mathbf{1 7}$ is very unstable, we were not able to isolate the uncomplexed fluoride. Analogously, the metathesis of $\mathrm{LScCl}_{2}$ with $\mathrm{Me}_{3} \mathrm{SnF}$ gave the labile adduct 16 .

\subsubsection{X-ray Structural Analysis of 17}

Complex 17 crystallises in two phases: $\mathbf{1 7 a}$ triclinic and $\mathbf{1 7 b}$ monoclinic. The two phases differ slightly. In the monoclinic phase the molecule lies on a two-fold axis resulting in a planar arrangement of $\mathrm{Sc}$ within the $\mathrm{NC}_{3} \mathrm{~N}$ plane while the deviation of the scandium atom from the same plane is $0.49 \AA$ in $\mathbf{1 7 a}$. One further significant difference has been found in the F-Sc-F angle $\left(162.2^{\circ}(\mathbf{1 7 a})\right.$ and $\left.171.2^{\circ}(\mathbf{1 7 b})\right)$. The following discussion will refer only to the triclinic phase because of the slightly better results of the refinement. At first glance the structure shows a non-linear trinuclear compound where 
the scandium atom is pseudooctahedraly surrounded and the geometry around the pentacoordinated tin is trigonal bipyramidal (F-Sn-Brav. 177.1 ${ }^{\circ}$ ) (Figure 10).

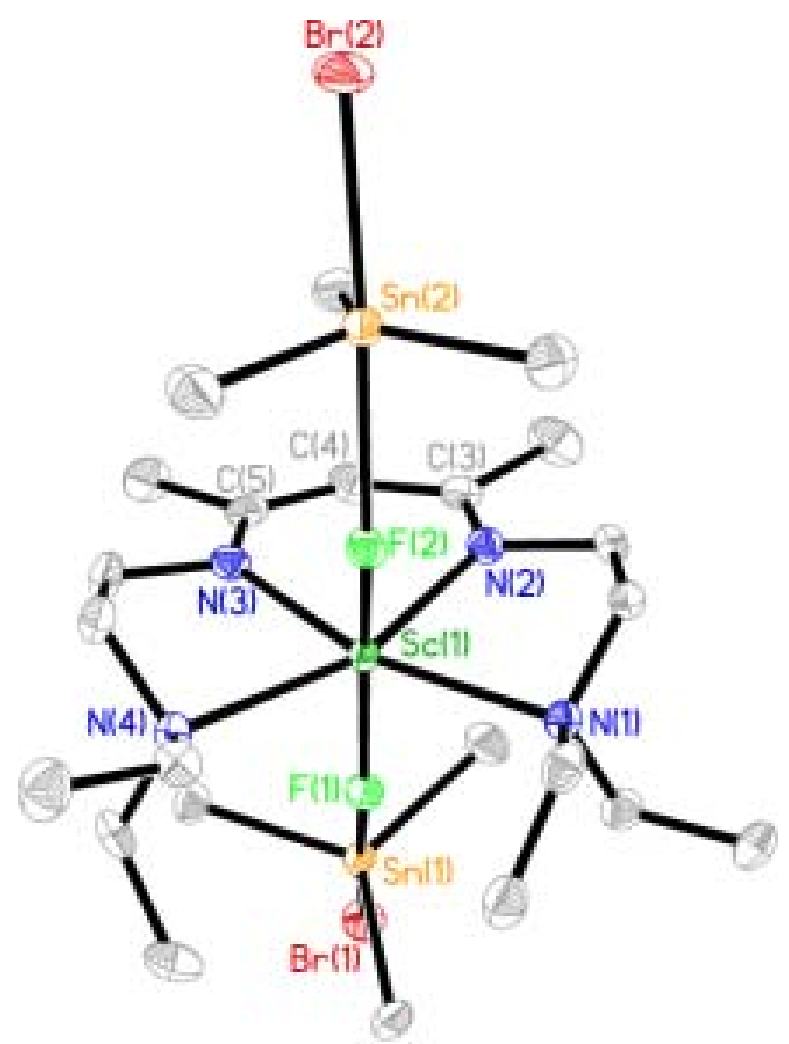

Figure 10: Molecular structure of 17 (50\% thermal ellipsoids probability, hydrogen atoms ommited for clarity).

Scandium is $\sigma$ bonded to the $\beta$-diketiminato backbone similar to the dibromo derivative (scandium is located $0.49 \AA$ outside of the $\mathrm{NC}_{3} \mathrm{~N}$ plane). The analogous deviations for 6, 15 and $\mathbf{1 7}$ are indicative that this kind of bonding is caused by the coordination of the metal to all four nitrogen atoms (8-electron donor) of the ligand. Consequently, the $\beta$-diketiminato backbone is acting as a 4-electron donor. A comparison of the bond lengths and angles of $\mathbf{6 , 1 5}$ and $\mathbf{1 7}$ shows that within the $\beta$-diketiminato frame these units are only marginally influenced by the different substituents on scandium. The Sc-F bond lengths are comparable to those reported in the literature (1.967(3) $\AA$ and 1.991(3) $\AA$ for 17a and av. $2.03 \AA$ for $\mathrm{Cp}_{2} \mathrm{ScF}^{[84]}$ ). The Sn-F bond lengths (2.421(4) $\AA$ and 2.455(5) $\AA$ ) are of the same order as the longest Sn-F distance in the polymeric $\mathrm{Me}_{3} \mathrm{SnF}^{[85]}$ having the same pentacoordination. The Sc-F-Sn bond angle 
averages $148.6^{\circ}$. A comparable intermediate was observed in the fluorination of a zirconium derivative ${ }^{[86]}$ with $\mathrm{Me}_{3} \mathrm{SnF}$. However, in the scandium case we cannot argue that $\mathbf{1 7}$ is an intermediate in the fluorination process. The $\mathrm{Me}_{3} \mathrm{Sn}$ units have similar coordination to those reported for zirconium compound.

Compound $\mathbf{1 6}$ crystallizes in the same monoclinic space group as $\mathbf{1 7 b}$ but, due to its even higher sensibility than $\mathbf{1 7}$, it decomposes and the X-ray data have a poor quality (lack of completeness $(84.1 \%)$ ).

Table 6. Selected bond lengths $(\AA)$ and angles $\left(^{\circ}\right)$ for $\mathbf{1 7 a}$ and $\mathbf{1 7 b}$

\begin{tabular}{|c|c|c|}
\hline Bond lengths & $17 \mathbf{a}$ & 17b \\
\hline$C(1)-C(2)$ & $1.382(7)$ & $1.407(6)$ \\
\hline $\mathrm{N}(1)-\mathrm{C}(1)$ & $1.323(6)$ & $1.329(6)$ \\
\hline $\operatorname{Sc}(1)-N(1)$ & $2.170(4)$ & $2.165(4)$ \\
\hline $\operatorname{Sc}(1)-N(2)$ & $2.148(4)$ & $2.165(4)$ \\
\hline $\operatorname{Sc}(1)-\mathrm{N}(4)$ & $2.421(4)$ & $2.390(4)$ \\
\hline $\operatorname{Sc}(1)-N(3)$ & $2.381(4)$ & $2.390(4)$ \\
\hline $\operatorname{Sc}(1)-F(1)$ & $1.967(3)$ & $2.000(3)$ \\
\hline $\operatorname{Sc}(1)-\mathrm{F}(2)$ & 1.991(3) & $2.000(3)$ \\
\hline $\mathrm{F}(1)-\operatorname{Sn}(1)$ & $2.419(3)$ & $2.425(3)$ \\
\hline$F(2)-\operatorname{Sn}(2)$ & $2.455(5)$ & $2.425(3)$ \\
\hline \multicolumn{3}{|l|}{ Angles } \\
\hline $\mathrm{N}(1)-\mathrm{Sc}(1)-\mathrm{N}(2)$ & $84.30(16)$ & $79.86(15)$ \\
\hline $\mathrm{N}(1)-\mathrm{Sc}(1)-\mathrm{N}(4)$ & $77.77(15)$ & $85.3(2)$ \\
\hline $\mathrm{N}(2)-\mathrm{Sc}(1)-\mathrm{N}(3)$ & $76.44(15)$ & $115.0(2)$ \\
\hline $\mathrm{N}(4)-\mathrm{Sc}(1)-\mathrm{N}(3)$ & $121.46(14)$ & $79.86(15)$ \\
\hline $\mathrm{F}(1)-\mathrm{Sc}(1)-\mathrm{F}(2)$ & $162.20(2)$ & $172.2(14)$ \\
\hline $\operatorname{Sc}(1)-F(1)-\operatorname{Sn}(1)$ & $149.28(14)$ & $148.53(14)$ \\
\hline $\operatorname{Sc}(1)-F(2)-\operatorname{Sn}(2)$ & $147.90(14)$ & $148.53(14)$ \\
\hline $\mathrm{F}(1)-\operatorname{Sn}(1)-\operatorname{Br}(1)$ & $177.47(7)$ & $175.93(6)$ \\
\hline$F(2)-\operatorname{Sn}(2)-\operatorname{Br}(2)$ & 176.726) & $175.93(6)$ \\
\hline
\end{tabular}

\subsubsection{Synthesis of the Yttrium Dimer $\left[\mathrm{LY}\left(\mathrm{N}\left(\mathrm{SiMe}_{3}\right)\left(\mathrm{SiMe}_{2}\right) \mathrm{NH}\right]_{2}(18)\right.$}

The organometallic chemistry of yttrium is also abounding in examples containing cyclopentadienyl substituents. Most of the derivatives containing one 
monoanionic spectator ligand were accessible through the silylamide route ${ }^{[8]}$ or by metathetical reactions of trialkyl- or trialkoxi-yttrium compounds. ${ }^{[57,87]}$ Examples of the reactivity of the dihalogeno derivatives are few. ${ }^{[26]}$

During the investigations of the reactivity of $\mathrm{LYCl}_{2}(7)$ an interesting behavior was observed upon treatment of 7 with $\mathrm{NaN}\left(\mathrm{SiMe}_{3}\right)_{2}$. Under the same conditions like for obtaining of compound 14, this reaction led repeatedly to an orange oil from which crystals of the dimeric yttrium complex $\mathbf{1 8}$ have been obtained in extremely low yields probably due to the minimal solubility of the compound in most organic solvents, as observed during attempts to characterize it and due to the fact that it is a secondary product. The molecule is destroyed under EI-MS conditions and the peaks correspond to smaller fragments like LY ( $m / z$ 471) or $\mathrm{LYNSiMe}_{3}(\mathrm{NH}) \mathrm{SiMe}_{2}(\mathrm{~m} / z$ 647). Through the solubility and the low amounts of available substance hampered the recording of interpretable NMR spectra (the ${ }^{1} \mathrm{H}$ NMR shows resonances due to the ligand and the $\mathrm{Me}_{3} \mathrm{Si}$ groups), the very good X-ray data allowed structural investigation in detail. The molecular structure of $\mathbf{1 8}$ is depicted in Figure 11.

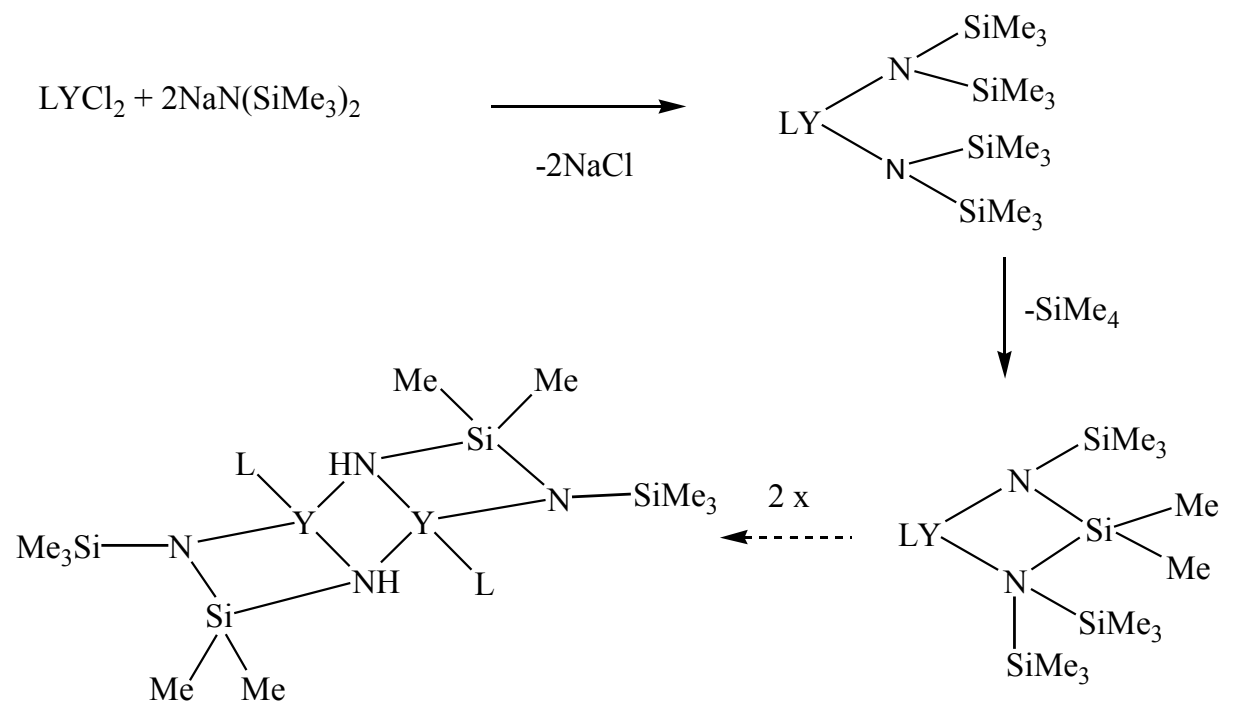

Scheme 5

For the formation of $\mathbf{1 8}$ proposing a mechanism is rather speculative. Probably after formation of the disilylamido derivate, elimination of $\mathrm{SiMe}_{4}$ takes place. This kind of elimination has a precedent in yttrium chemistry occurring in polyalkyl complexes. ${ }^{[8,88 a]} \mathrm{A}$ further rearrangement and dimerization follow assisted by the yttrium 
atom. Herrmann et al. reported a case where the silylamide fragmentation reached the amine stage. ${ }^{[88 \mathrm{~b}]}$

\subsubsection{X-ray Structural Analysis of $\left[\mathrm{LY}\left(\mathrm{N}\left(\mathrm{SiMe}_{3}\right)\left(\mathrm{SiMe}_{2}\right) \mathrm{NH}\right]_{2}(18)\right.$}

The dimer crystallizes in the monoclinic space group $P 2_{1} / n$ with half of the molecule in the asymmetric unit and it contains a molecule of toluene in the cell.
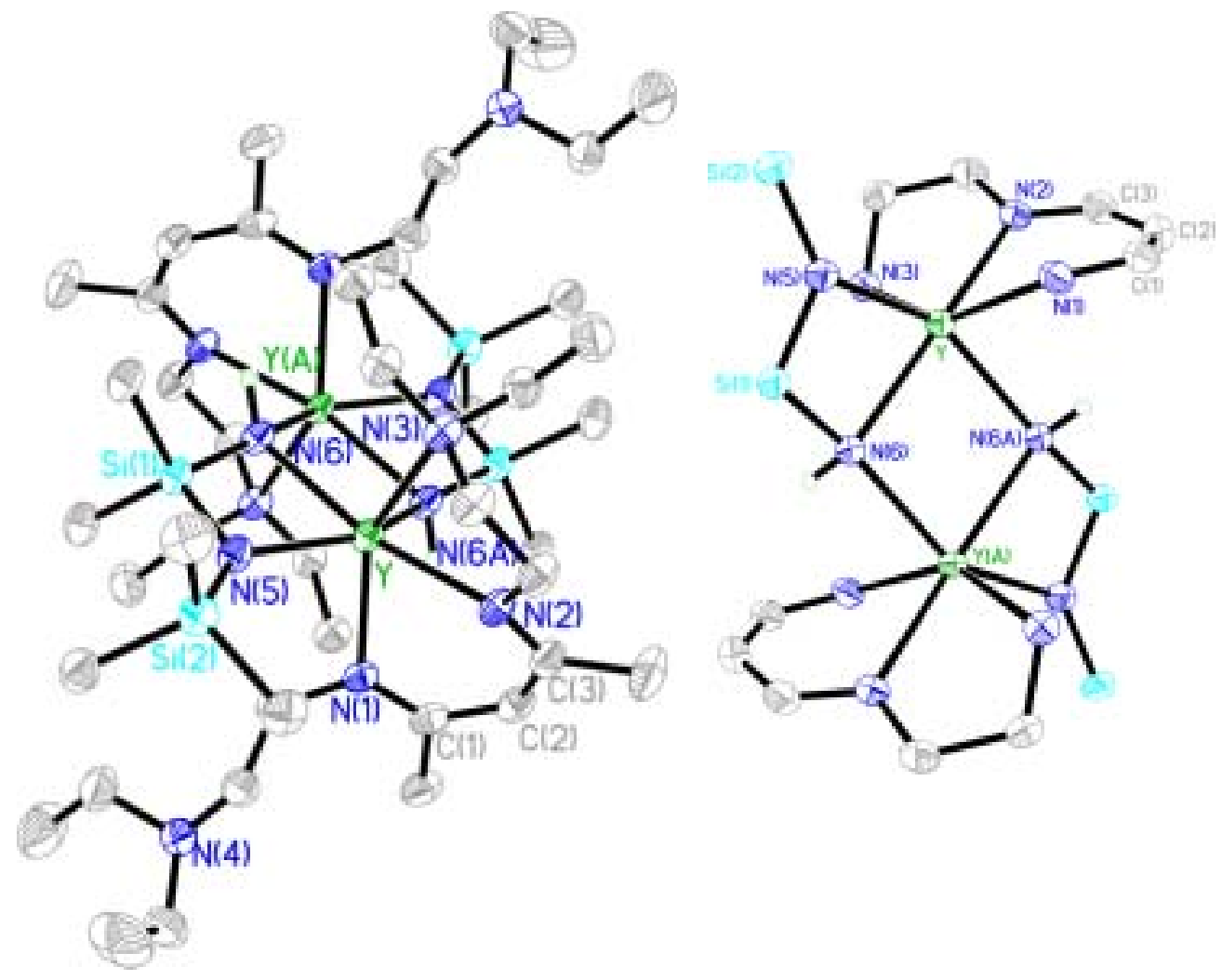

Figure 11: Molecular Structure of $\mathbf{1 8}$ (50 \% thermal ellipsoids probability, hydrogen atoms and toluene ommited for clarity)(left); Core of $\mathbf{1 8}$ (right).

Compound 18 consists of a polycyclic structure with each yttrium atom in a distorted octahedral environment surrounded by three nitrogen atoms of the ligand L, by the two nitrogen atoms of a $\mathrm{NSiMe}_{3}(\mathrm{NH}) \mathrm{SiMe}_{2}$ fragment, and another $\mathrm{NH}$ unit from the other half of the molecule forming an essentially planar four-membered ring $\mathrm{Y}_{2} \mathrm{~N}_{2}$ (as a consequence of an inversions center which halves the molecule). The ligands $\mathrm{L}$ and the $\mathrm{N}_{2}$ Si moieties occupy trans positions with respect to the $\mathrm{Y}-\mathrm{Y}(\mathrm{A})$ vector. $\mathrm{Y}, \mathrm{N}(6), \mathrm{Si}(1)$, 
$\mathrm{N}(5)$ belong to the same plane (deviation from the planarity $0.008 \AA$ ). The whole molecule is neutral having two $\mathrm{Y}^{3+}, 2 \mathrm{~L}$, and the two negative charged $\mathrm{NH}$ moieties in the bridges. The positions of the two hydrogen atoms connected to N(6) and N(7) have been freely refined as a proof of their existence. The Y-N bond lengths vary due to the different coordination environments and type of bonds: the shortest is the bond with the nitrogen of the bis(trimethylsilyl)amide group (Y-N(5) 2.288(2) $\AA$ fits in the range for the $\left.\mathrm{Y}-\mathrm{N}\left(\mathrm{SiMe}_{3}\right)_{2}\right) .{ }^{[89]}$ The next are the $\mathrm{Y}-\mathrm{N}$ bonds to the ligand which are normally longer as a consequence of a $2 \sigma-\pi$ bonded $\mathrm{Y}$ - $\beta$-diketiminato backbone ( $\mathrm{Y}$ is bent away (1.094(10) $\AA$ ) from the $\mathrm{N}(1) \mathrm{C}(1) \mathrm{C}(2) \mathrm{C}(3) \mathrm{N}(2)$ plane) and the longest being $\mathrm{Y}-\mathrm{N}(3)$ as a coordinative bond. The length Y-N(bridge), not equally long, are bigger than Y-N(5) generally accepted for bridges.

Table 7. Selected bond lengths $(\AA)$ and angles $\left(^{\circ}\right)$ for $\mathbf{1 8}$

\begin{tabular}{|llll|}
\hline Bond lengths & \multicolumn{3}{l|}{ Angles } \\
\hline $\mathrm{Y}-\mathrm{N}(1)$ & $2.372(2)$ & $\mathrm{N}(5)-\mathrm{Y}-\mathrm{N}(6)$ & $69.70(8)$ \\
$\mathrm{Y}-\mathrm{N}(2)$ & $2.383(2)$ & $\mathrm{N}(6)-\mathrm{Y}-\mathrm{N}(6 \mathrm{~A})$ & $79.48(10)$ \\
$\mathrm{Y}-\mathrm{N}(3)$ & $2.596(2)$ & $\mathrm{Y}(\mathrm{A})-\mathrm{N}(6)-\mathrm{Y}$ & $100.52(10)$ \\
$\mathrm{Y}-\mathrm{N}(5)$ & $2.288(2)$ & $\mathrm{N}(5)-\mathrm{Si}(1)-\mathrm{N}(6)$ & $101.84(11)$ \\
$\mathrm{Y}-\mathrm{N}(6)$ & $2.415(2)$ & $\mathrm{N}(1)-\mathrm{Y}-\mathrm{N}(2)$ & $77.22(8)$ \\
$\mathrm{Y}-\mathrm{N}(6 \mathrm{~A})$ & $2.369(2)$ & $\mathrm{Si}(1)-\mathrm{N}(5)-\mathrm{Y}$ & $96.92(9)$ \\
$\mathrm{Y}-\mathrm{Si}(1)$ & $3.0197(11)$ & $\mathrm{Si}(1)-\mathrm{N}(6)-\mathrm{Y}$ & $91.52(10)$ \\
$\mathrm{Si}(1)-\mathrm{N}(5)$ & $1.714(2)$ & $\mathrm{N}(1)-\mathrm{C}(1)-\mathrm{C}(2)$ & $124.0(3)$ \\
$\mathrm{Si}(1)-\mathrm{N}(6)$ & $1.750(2)$ & $\mathrm{C}(1)-\mathrm{C}(2)-\mathrm{C}(3)$ & $128.9(3)$ \\
$\mathrm{Si}(2)-\mathrm{N}(5)$ & $1.701(2)$ & $\mathrm{N}(2)-\mathrm{C}(3)-\mathrm{C}(2)$ & $124.3(3)$ \\
\hline
\end{tabular}

\subsection{Compounds in Formal Low Oxidation States}

Samarium, europium and ytterbium in low oxidation states have proved their usefulness in many organic processes. ${ }^{[8]}$ Studies of their behaviour in different ligand environments is also useful for tuning their properties onto the desired direction. ${ }^{[90]}$ On the other hand, by solid-state chemistry methods, compounds with all the rare earths in formal low oxidation states can be obtained. The challenge in this area is to obtain these compounds as molecular complexes preferable in solution. 


\subsubsection{Synthesis of the Sandwich $\mathrm{Sc}^{1+}$ Complex (LMgBr) $)_{2} \mathrm{ScBr}(19)$}

The main technique used for the accessing of the low oxidation states in different ligand environments for these metals apart from samarium, europium, and ytterbium is metal vapor synthesis. ${ }^{[35,36]}$ In most of the compounds containing rare earth metals in $(0)$ or (I) oxidation states the stabilization is achieved by use of considerably bulky ligands with $\pi$-acceptor properties ${ }^{[36]}$ which support the back donation of the electron density from the metal. Scandium can be considered as a bridge element between lanthanide and transition metals. Due to its properties it is in many ways similar to aluminum. The synthesis of aluminum $(+1)$ compound as a monomeric species ${ }^{[91]}$ offered enough reasons to attempt the synthesis in solution also of a scandium(I) species. Unfortunately, classic reductive methods gave in this case no result. The reaction of a THF solution of $\mathrm{LScBr}_{2}$ (6) with two equivalents of $\left(\mathrm{C}_{3} \mathrm{H}_{5}\right) \mathrm{MgBr}$ in diethylether was accompanied by a color change from yellow to dark brown at room temperature after a few hours. After removal all of the solvent and extraction of the remaining solid with toluene, a dark blue solution was obtained from which crystals suitable for a X-ray investigation have been grown over night at room temperature. ${ }^{[92]}$ The reaction is reproducible in variable yields (from 10 to $25 \%$ ). Complex 19 is very air- and moisture sensitive as seen from the immediate decoloration upon exposure to air.

\subsubsection{X-ray Analysis and Structure Discussion for 19}

Compound 19 crystallizes in the orthorhombic space group $\mathrm{Cmcm}$ having the scandium atom in the special position from the intersection of a two fold axe with two perpendicular planes, with one molecule of toluene that interact in no way with the rest of the molecule and it can be partially removed by drying but a prolonged drying under vacuum or nitrogen led to decomposition. As far as the structure is concerned, there are several interesting features (Figure 12).

The molecular symmetry is $C_{2 v}$. The two $\mathrm{LMgBr}$ frames surround the scandium atom symmetrically in a sandwich-like structure, having a certain similarity with $\mathrm{Cp}_{2} \mathrm{ScCl}$ where the $\mathrm{Cp}$ groups are arranged in a bent fashion (the distance from Sc to the $\mathrm{C}_{3} \mathrm{~N}_{2}$ ligand frame is $1.76(4) \AA) .{ }^{[6]}$ The coordination number of scandium in $\mathbf{1 9}$ is 11 . The Sc- 
$\operatorname{Br}(1)$ bond length of 19 is longer by $0.19 \AA$ compared to that of $\mathrm{LScBr}_{2}$ as a consequence of the larger radius of $\mathrm{Sc}^{1+}$ in comparison with $\mathrm{Sc}^{3+} \cdot{ }^{24]}$ The stronger bonds between scandium and the nitrogen atoms compared to those of scandium and the carbon atoms are seen from the structural data. The scandium atom is only 0.16(4) $\AA$ out of the plane formed by $\mathrm{N}(1), \mathrm{N}(1) \# 2, \mathrm{~N}(1) \# 3, \mathrm{~N}(1) \# 1$. Interestingly, the Sc-C(1) and $\mathrm{Sc}-\mathrm{C}(2)$ bond lengths in 19 are comparable with the Sc-C (enclosed in the benzene-like ring) bond lengths for $\left[\left(\eta^{5}-\mathrm{P}_{3} \mathrm{C}_{2}{ }^{t} \mathrm{Bu} 2\right) \operatorname{Sc}\left(\mu-\eta^{6}: \eta^{6}-\mathrm{P}_{3} \mathrm{C}_{3}{ }^{t} \mathrm{Bu}_{3}\right) \operatorname{Sc}\left(\eta^{5}-\mathrm{P}_{3} \mathrm{C}_{2}{ }^{t} \mathrm{Bu}_{2}\right)(2.450(5) \AA) .{ }^{[36]}\right.$
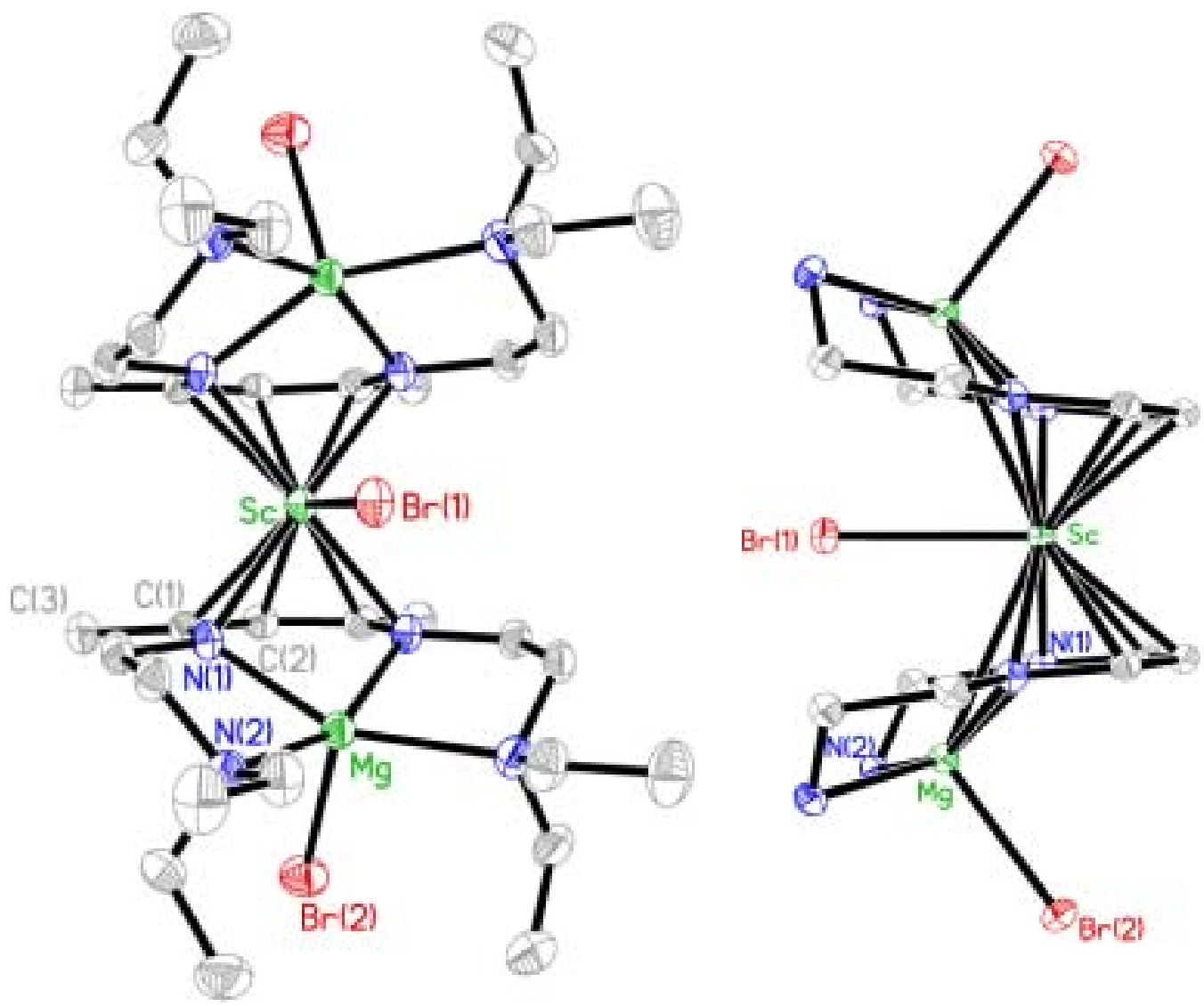

Figure 12: Molecular structure of 19 (50\% thermal ellipsoids probability) (left); simplified structure of 19 (right)( hydrogen atoms ommited for clarity)

The $\mathrm{N}(1)-\mathrm{C}(1)$ bond is slightly longer than that in $\mathrm{LScBr}_{2}$ by roughly $0.05 \AA$ as an effect of the higher coordination number of the nitrogen atoms of the ligand frame. However, no significant differences have been observed for the $\mathrm{C}(1)-\mathrm{C}(2)$ bond lengths in 19 in comparison with those from $\mathrm{LScBr}_{2}$. The magnesium atoms are pentacoordinated. All the nitrogen atoms coordinated to magnesium adopt a square planar 
pyramidal geometry around the metal center. The magnesium atom lies out of the $(\mathrm{N}(1)$, $\mathrm{N}(1) \# 2, \mathrm{~N}(2), \mathrm{N}(2) \# 2)$ plane by $0.40 \AA$ in the direction of the bromine atom. The Mg-N bond lengths are not equal due to the different bonding modes of the nitrogen atoms to the magnesium atoms. The $\mathrm{Mg}-\mathrm{N}(1)$ bond length is slightly different from those encountered in similar compounds, previously reported. ${ }^{[93]}$ The $\operatorname{Mg}-\operatorname{Br}(2)$ bond length (2.534(1) $\AA$ ) demonstrates a partially covalent nature of this bond (the sum of ionic radii for $\mathrm{Mg}^{2+}$ and $\mathrm{Br}^{-}$is $2.60 \AA$ ) (Table 8). ${ }^{[24]}$

Table 8. Selected bond lengths $(\AA)$ and angles $\left(^{\circ}\right)$ for $\mathbf{1 9}$ (Symmetry transformations used to generate equivalent atoms: \#1 -x,y,z; \#2 x,y,-z+3/2; \#3-x,y,-z+3/2

\begin{tabular}{|llll|}
\hline Bond lengths & \multicolumn{3}{l|}{ Angles } \\
\hline Sc-Br(1) & $2.800(1)$ & $\mathrm{N}(1)-\mathrm{C}(1)-\mathrm{C}(2)$ & $121.0(2)$ \\
Sc-N(1) & $2.274(2)$ & $\mathrm{C}(1)-\mathrm{C}(2)-\mathrm{C}(1) \# 2$ & $129.1(4)$ \\
Sc-C(1) & $2.413(3)$ & $\mathrm{N}(1)-\mathrm{Sc}-\mathrm{N}(1) \# 1$ & $102.91(11)$ \\
$\mathrm{Sc}-\mathrm{C}(2)$ & $2.431(4)$ & $\mathrm{C}(1)-\mathrm{Sc}-\mathrm{C}(1) \# 1$ & $86.65(12)$ \\
$\mathrm{N}(1)-\mathrm{C}(1)$ & $1.385(3)$ & $\mathrm{C}(2)-\mathrm{Sc}-\mathrm{C}(2) \# 3$ & $83.45(19)$ \\
$\mathrm{C}(1)-\mathrm{C}(2)$ & $1.411(3)$ & $\mathrm{N}(1)-\mathrm{Sc}-\mathrm{Br}(1)$ & $85.85(6)$ \\
$\operatorname{Mg}-\mathrm{N}(1)$ & $2.142(2)$ & $\mathrm{N}(1)-\mathrm{Mg}-\mathrm{Br}(2)$ & $98.98(7)$ \\
$\operatorname{Mg}-\mathrm{N}(2)$ & $2.345(2)$ & $\mathrm{N}(1)-\mathrm{Mg}-\mathrm{N}(2)$ & $79.76(8)$ \\
$\operatorname{Mg}-\mathrm{Br}(2)$ & $2.534(1)$ & $\mathrm{N}(2)-\mathrm{Mg}-\mathrm{N}(2) \# 2$ & $110.62(12)$. \\
\hline
\end{tabular}

The composition of the unanticipated molecular formula $(\mathrm{LMgBr})_{2} \mathrm{ScBr}$ that resulted from the X-ray structural analysis is consistent with ${ }^{1} \mathrm{H},{ }^{13} \mathrm{C}$, and ${ }^{45} \mathrm{Sc} \mathrm{NMR}$ data in solution. The elemental analysis was determined for $(\mathrm{LMgBr})_{2} \mathrm{ScBr}$ with half a molecule of toluene.

It is noteworthy that all the hydrogen atoms can be assigned with one major upfield shift $(2 \mathrm{ppm})$ namely the hydrogen atom bonded directly to the backbone, $\mathrm{C}(\mathrm{Me}) \mathrm{CHC}(\mathrm{Me})$. Also the resonance of the ${ }^{45} \mathrm{Sc}$ NMR spectrum is shifted upfield from $335.0 \mathrm{ppm}$ in $\mathrm{LScBr}_{2}$ to $167.5 \mathrm{ppm}$ in 19. Temperature dependent NMR experiments showed that 19 started to decompose irreversibly in solution from $50{ }^{\circ} \mathrm{C}$ onwards but a certain degree of decomposition is also observed at $28{ }^{\circ} \mathrm{C}$ (see Figure 13). Here, the indicatives of the decomposition are the resonance from $0.91 \mathrm{ppm}\left(\mathrm{br}, 24 \mathrm{H}, \mathrm{NCH}_{2} \mathrm{CH}_{3}\right)$ that with increasing temperature shifts upfield (towards $0.8 \mathrm{ppm}$ ) where the resonances of 
the corresponding methyl groups in uncoordinated $\mathrm{LMgBr}$ appear and the resonance corresponding to the proton from $\gamma$-position referred to $\mathrm{Mg}$ in the $\mathrm{LMgBr}$ moieties which have significantly different positions in coordinated and uncoordinated units. At room temperature, when the degree of decomposition is irrelevant, the resonance from $\delta 4.74$ ppm (the proton resonance in uncoordinated $\mathrm{LMgBr}$ ) is not observable but at $90{ }^{\circ} \mathrm{C}$ this becomes evident and it remains with even after cooling back to $28^{\circ} \mathrm{C}$.

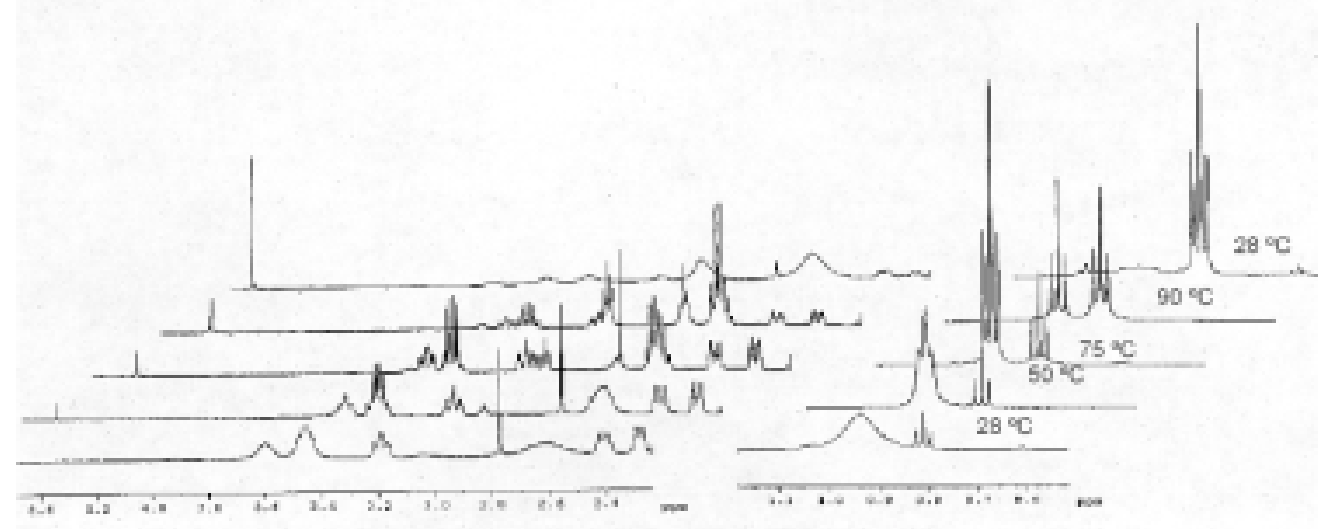

Figure 13: Temperature dependent ${ }^{1} H N M R\left(C_{6} D_{6}\right)$ spectra in the ranges $0.75-1.2$ ppm and $2.3-4.4 \mathrm{ppm}$ (the percentage of the degradation product is increasing with the temperature (for instance the increasing of the decomposition gradient can be seen at 0.8 ppm)).

In addition, the decomposition was confirmed with mass spectral investigations where only the fragment $\mathrm{LMgBr}$ could be assigned. Furthermore, in the UV-vis spectrum, an absorption at $570 \mathrm{~nm}\left(\mathrm{C}_{6} \mathrm{D}_{6}\right)$ was observed $\left(\varepsilon=0.18 \cdot 10^{4}\right)$. Intriguingly, compound 19 showed no paramagnetic behavior by any means, as one could expect taking into account the previous subvalent complex of scandium prepared by Cloke, Nixon et al. ${ }^{[41]}$ When temperature dependent EPR spectra were recorded for a toluene solution of 19, no signal has been observed $\left(-70^{\circ} \mathrm{C}\right.$ to r.t.). Therefore, in order to investigate any possible structural changes of 19 in solution compared to the solid-state, additional solid-state NMR experiments were conducted under Magic Angle Spinning $(\mathrm{MAS})^{[94]}$ conditions. A Floquet analysis ${ }^{[94 \mathrm{~b}]}$ of the resulting ${ }^{45} \mathrm{Sc}$ spinning sidebands 
spectra resulted in an isotropic chemical shift value consistent with the results obtained in solution, $160 \mathrm{ppm}$ compared to $167 \mathrm{ppm}$ in solution; also a solid state ${ }^{45} \mathrm{Sc}$ NMR was measured for compound $\mathbf{6}$ to confirm the reliability of the measurements and the result was $325 \mathrm{ppm}$ compared to $335 \mathrm{ppm}$ in solution. Likewise, the ${ }^{13} \mathrm{C}$ chemical shifts observed under MAS conditions are consistent with the data obtained in solution. However, in order to demonstrate that indeed a redox reaction took place a GC-MS experiment was designed. For this purpose the reaction was carried out in deuterated THF and all the volatiles were collected. The corroboration of the GC-MS and ${ }^{1} \mathrm{H}$ NMR spectrum of the volatiles revealed that 1,5-hexadiene was the only byproduct that clearly shows that a redox reaction took place (see Equation 6). Still, the exact amount of 1,5hexadiene and the nature of the other side products of the reaction could not be isolated and characterized.

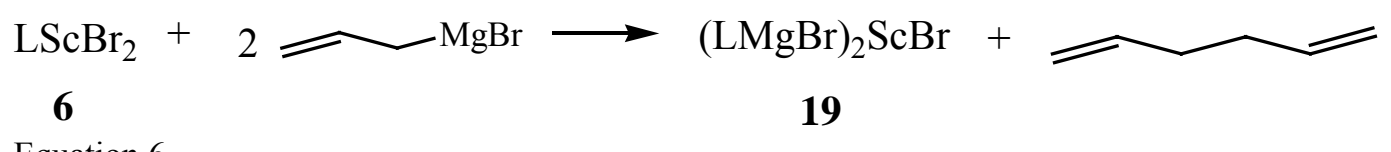

Equation 6

\subsubsection{Theoretical Calculations on 19}

Understanding the structure of $\mathbf{1 9}$ required a closer investigation by computational methods. A DFT study was performed on the model system ( $\left.{ }^{\prime} \mathrm{MgBr}\right)_{2} \mathrm{ScBr}$ with $\mathrm{L}^{\prime}=$ $\left.\mathrm{H}_{2} \mathrm{NCH}_{2} \mathrm{CH}_{2} \mathrm{NC}(\mathrm{Me}) \mathrm{CHC}(\mathrm{Me}) \mathrm{NCH}_{2} \mathrm{CH}_{2} \mathrm{NH}_{2} \cdot{ }^{[95} \mathrm{a}-\mathrm{f}\right]$
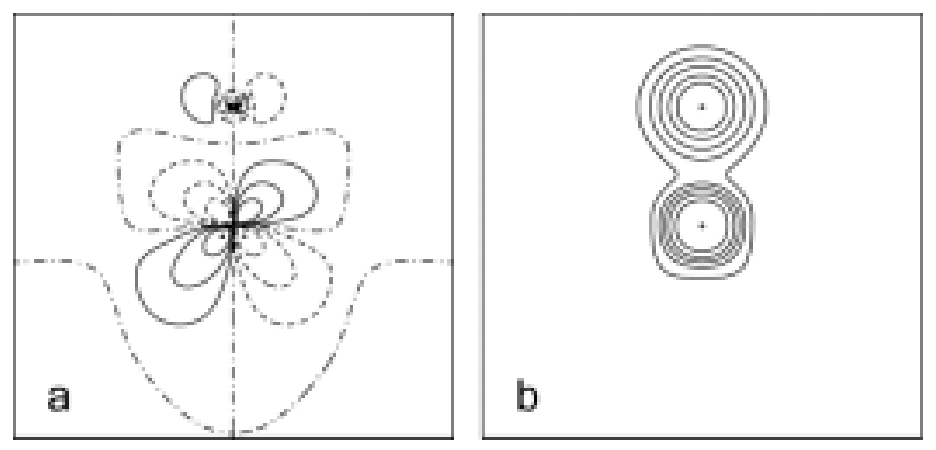

Figure 14:

Shown in Figure 14a is a contour plot of the molecule's highest occupied molecular orbital (HOMO) in the yz plane, with Sc located at the origin. The Sc-Br 
vector defines the $\mathrm{z}$ axis (vertical) and the HOMO in the $C_{2 \mathrm{v}}$ point group has $b_{2}$ symmetry. The HOMO is thus comprised largely of the scandium $d_{\mathrm{yz}}$ orbital, which is antibonding with respect to the filled bromine $p_{\mathrm{y}}$ orbital. Nodal surfaces cutting through the yz plane are indicated in Figure 14a by dash-dot-dash lines, while solid lines and dashes denote positive and negative contours, respectively. From the standpoint of energy considerations, the HOMO depicted in Figure 14a is located nearly equidistant between the HOMO-1 and LUMO orbitals, a characteristic typically identified with a nonbonding (lone pair) orbital. This is consistent with assigning a formal +1 oxidation state to the scandium center. Examination of the HOMO in three dimensions suggests a small degree of stabilization by virtue of $\delta$-backbonding to the two heterocyclic rings sandwiching the scandium atom (Figure 15).

Figure $14 \mathrm{~b}$ encompasses the same $10 \times 10 \AA^{2}$ area in the yz plane as does Figure $14 \mathrm{a}$, but it displays contours corresponding to the total SCF electron density. The bromine atom (top) and the scandium atom (bottom) are the only atoms that have significant electron density in the yz plane within this area.

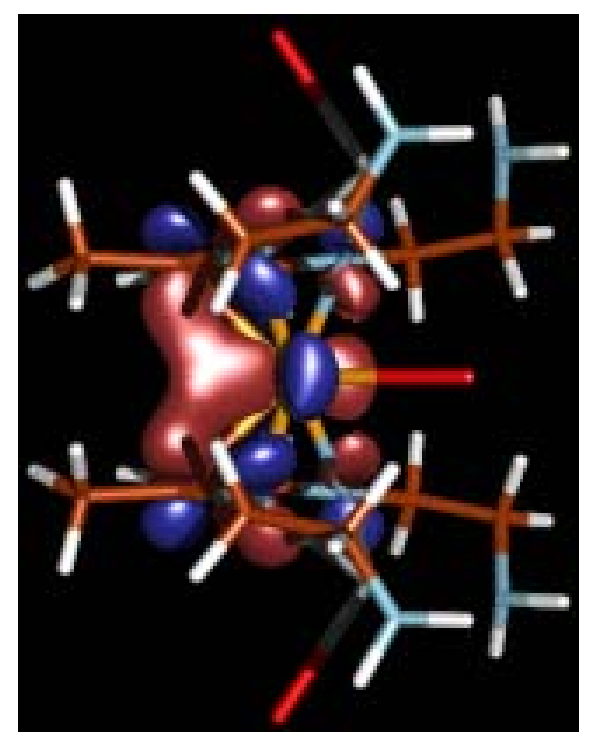

Figure 15: HOMO orbital of $\mathbf{1 8}$ in three dimensions.

The Amsterdam Density Functional package (version $A D F 2000.02$ ) was used also to derive the ${ }^{45} \mathrm{Sc}$ NMR chemical shift values for complexes 5, 6, and $\mathbf{1 9}$ leading to good agreement between the experimental and the theoretical data. ${ }^{[95 \mathrm{a}-\mathrm{c}, 95 \mathrm{~g}]}$ In figure 16 is 
represented a plot calculated NMR tensors $v s$. real ${ }^{45} \mathrm{Sc}$ chemical shifts. For a good agreement the dependency should fit a line. This is a useful tool for predicting one of the variables when the other one is given even for a scandium compound with an unknown structure.

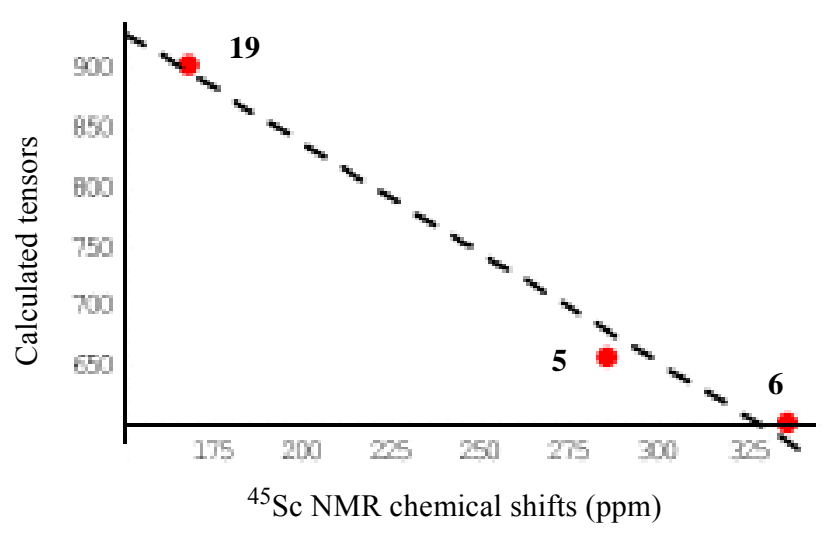

Figure 16: Plot calculated NMR tensors vs. real ${ }^{45}$ Sc chemical shifts for compounds 5, 6, and $19(f(x)=$ $1205.5-1.84434 x)$.

Lately a subvalent scandium compound with 1,2,4-triphophacyclopentadienyl ligand, $\left[\left\{\mathrm{Sc}\left(\mathrm{P}_{3} \mathrm{C}_{2}{ }^{t} \mathrm{Bu}_{2}\right)_{2}\right\}_{2}\right]$, was reported by Cloke et al. ${ }^{[38 \mathrm{~b}]}$ This compound presented as a mixed valence dimmer $\mathrm{Sc}(\mathrm{I})-\mathrm{Sc}(\mathrm{III})$ has a color and magnetic behaviour similar to those of $\mathbf{1 9}$ and the theoretical calculations revealed the involvement of a $\delta$ bond for its stabilization.

Although the data led to the conclusion that in $\mathbf{1 9}$ the oxidation state of scandium is +1 and the calculations concluded that the electrons responsible for the diamagnetic behavior are situate on a Sc $\mathrm{d}_{x y}$ orbital it was still complicated to conceive an experiment in which scandium can maintain its oxidation state. ${ }^{[96]}$ This is because the disposition and the electronic configuration of $\mathrm{LMgBr}$ have a decisive contribution to the complex stability and attempts to exchange it with other ligands failed. So, investigation of the reactivity had to go in the direction of redox reactions with substrates possessing acidic hydrogen atoms like alcohols and, unquestionable, water. 


\subsubsection{Reaction of $(\mathrm{LMgBr})_{2} \operatorname{ScBr}(19)$ with water. Synthesis of $\operatorname{LSc}\left(B\left(\mathrm{C}_{6} \mathrm{~F}_{5}\right)_{2}\right)_{2}(20)$}

For a controlled hydrolysis $\mathrm{H}_{2} \mathrm{O} \cdot \mathrm{B}\left(\mathrm{C}_{6} \mathrm{~F}_{5}\right)_{3}$ was chosen and $\mathbf{2 0}$ was isolated as the product. Molecular structure of $\mathbf{2 0}$ is depicted in Figure 16. Trapping the volatiles following the reaction and analyzing the components via $\mathrm{GC}-\mathrm{MS}, \mathrm{C}_{6} \mathrm{~F}_{5} \mathrm{H}$ was evidenced as a byproduct (see Equation 7).

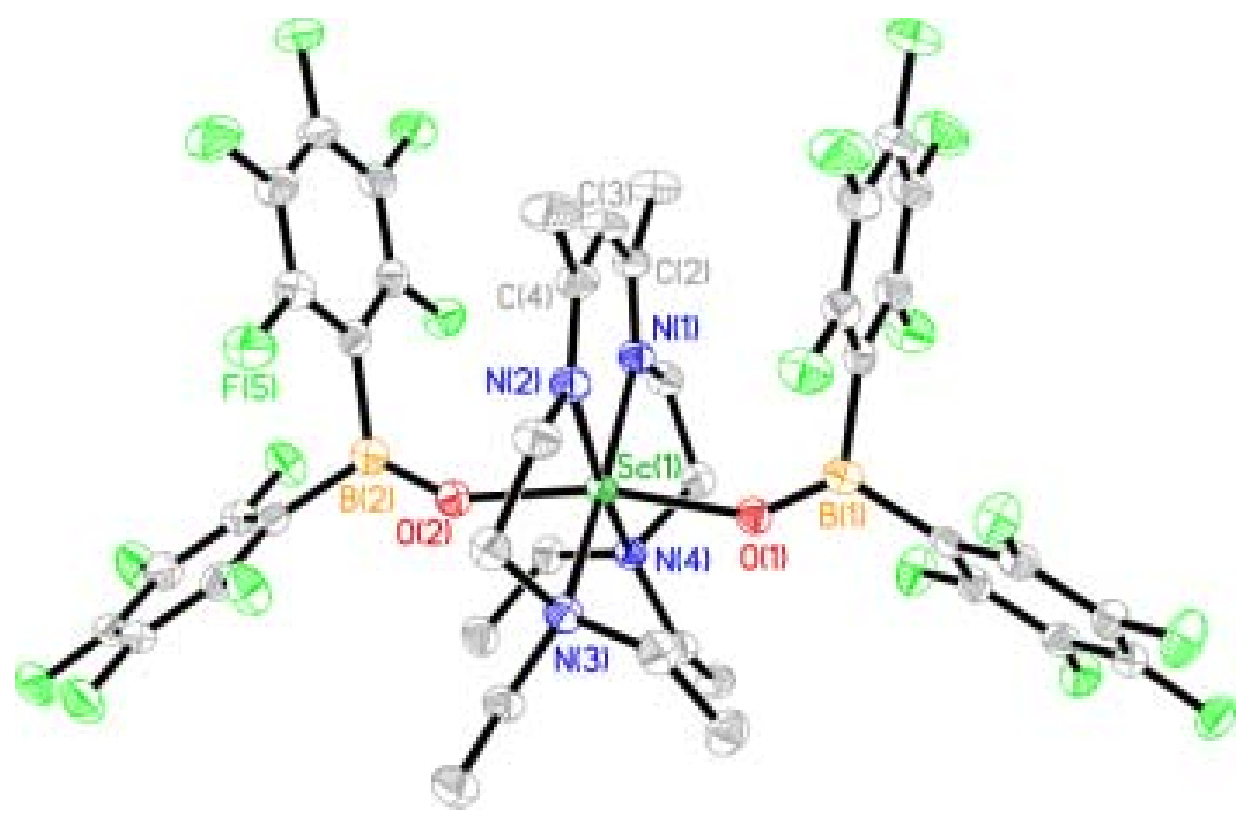

Figure 16: Molecular structure of $\mathbf{2 0}$ (50\% thermal ellipsoids probability, hydrogen atoms and toluene ommited for clarity).
$(\mathrm{LMgBr})_{2} \mathrm{ScBr}+\mathrm{H}_{2} \mathrm{O} \cdot \mathrm{B}\left(\mathrm{C}_{6} \mathrm{~F}_{5}\right)_{3} \longrightarrow \mathrm{LSc}\left(\mathrm{OB}\left(\mathrm{C}_{6} \mathrm{~F}_{5}\right)_{2}\right)_{2}+\mathrm{C}_{6} \mathrm{~F}_{5} \mathrm{H}+\mathrm{H}_{2}+$ unidentified 19 20 products

Equation 7

With these results a path can be proposed that implies the formal reduction of water by scandium that is oxidized to $\mathrm{Sc}^{3+}$. The ligand $(\mathrm{L})$ stabilize the oxidized scandium and the $\mathrm{B}\left(\mathrm{C}_{6} \mathrm{~F}_{5}\right)_{3}$ molecule is degraded. ${ }^{[97]}$

\subsubsection{X-ray Structural Analysis of 20}

In compound 20 scandium adopts a pseudooctahedral geometry $(\mathrm{O}(1)-\mathrm{Sc}-\mathrm{O}(2)$ $166.1^{\circ}$ ) forming a perfectly planar 6-membered ring with the $\beta$-diketiminato backbone. The differences in bond lengths within the $\beta$-diketiminato moiety of $\mathbf{1 9}, \mathbf{2 0}$, and $\mathrm{LScBr}_{2}$ 
(6) are negligible $(\mathrm{C}(1)-\mathrm{C}(2) 1.411(3) \AA$ in 19, 1.402(4) $\AA$ in 20, and 1.394(4) $\AA$ in $\mathrm{LScBr}_{2}$; $\mathrm{N}(1)-\mathrm{C}(1)$ 1.385(4) $\AA$ in 19, 1.331(3) $\AA$ in 20, and 1.340(3) $\AA$ in $\mathrm{LScBr}_{2}$ ) and the B-O bond lengths in 20 ( $a v \cdot 1.292 \AA$ ) are also very close to a covalent B-O bond $\left(\begin{array}{ll}1.311 \AA \\ )\end{array}{ }^{[97]}\right.$ much shorter than the coordinative $\mathrm{B}-\mathrm{O}$ bond found in $\mathrm{H}_{2} \mathrm{O} \cdot \mathrm{B}\left(\mathrm{C}_{6} \mathrm{~F}_{5}\right)_{3}$ $\left(1.597^{\circ} \AA\right.$ ) (see Table 10). ${ }^{[98]}$ An interesting feature of this structure is the stacking of two from four $\mathrm{C}_{6} \mathrm{~F}_{5}$ cycles to the $\mathrm{ScNC}_{3} \mathrm{~N}$ ring, thus directly influencing the electron density on the proton from the $\mathrm{C}(\mathrm{Me}) \mathrm{CHC}(\mathrm{Me})$ position whose resonance in the ${ }^{1} \mathrm{H}-\mathrm{NMR}$ spectrum is significantly shifted upfield from $\delta 4.82 \mathrm{ppm}$ in $\mathrm{LScBr}_{2}$ to $3.51 \mathrm{ppm}$ in 20 . As expected the crystal packing evidences $\pi$ - $\pi$ stacking interactions between the $\mathrm{C}_{6} \mathrm{~F}_{5}$ moieties belonging to different molecules.

Table 9. Selected bond lengths $(\AA)$ and angles $\left(^{\circ}\right)$ for $\mathbf{2 0}$

\begin{tabular}{|llll|}
\hline Bond lengths & \multicolumn{3}{l|}{ Angles } \\
\hline $\mathrm{C}(1)-\mathrm{C}(2)$ & $1.508(4)$ & $\mathrm{O}(1)-\mathrm{Sc}-\mathrm{O}(2)$ & $166.1(7)$ \\
$\mathrm{C}(4)-\mathrm{C}(5)$ & $1.521(4)$ & $\mathrm{C}(2)-\mathrm{C}(3)-\mathrm{C}(4)$ & $129.5(2)$ \\
$\mathrm{C}(2)-\mathrm{C}(3)$ & $1.402(4)$ & $\mathrm{Sc}(1)-\mathrm{O}(1)-\mathrm{B}(1)$ & $145.83(17)$ \\
$\mathrm{N}(1)-\mathrm{C}(2)$ & $1.331(3)$ & $\mathrm{Sc}(1)-\mathrm{O}(2)-\mathrm{B}(2)$ & $149.90(17)$ \\
$\mathrm{B}(1)-\mathrm{O}(1)$ & $1.295(3)$ & $\mathrm{N}(1)-\mathrm{Sc}(1)-\mathrm{N}(2)$ & $85.34(8)$ \\
$\mathrm{B}(2)-\mathrm{O}(2)$ & $1.290(3)$ & $\mathrm{N}(1)-\mathrm{C}(2)-\mathrm{C}(3)$ & $123.9(2)$ \\
$\mathrm{Sc}(1)-\mathrm{O}(1)$ & $2.0550(18)$ & $\mathrm{N}(2)-\mathrm{C}(4)-\mathrm{C}(3)$ & $124.1(2)$ \\
$\mathrm{Sc}(1)-\mathrm{O}(2)$ & $2.0477(17)$ & $\mathrm{N}(1)-\mathrm{Sc}(1)-\mathrm{N}(3)$ & $79.15(8)$ \\
$\mathrm{Sc}(1)-\mathrm{N}(1)$ & $2.163(2)$ & $\mathrm{N}(2)-\mathrm{Sc}(1)-\mathrm{N}(4)$ & $79.15(8)$ \\
$\mathrm{Sc}(1)-\mathrm{N}(2)$ & $2.171(2)$ & $\mathrm{N}(3)-\mathrm{Sc}(1)-\mathrm{N}(4)$ & $116.59(7)$ \\
$\mathrm{Sc}(1)-\mathrm{N}(3)$ & $2.402(2)$ & $\mathrm{C}(2)-\mathrm{N}(1)-\mathrm{Sc}(1)$ & $128.62(17)$ \\
$\mathrm{Sc}(1)-\mathrm{N}(4)$ & $2.392(2)$ & $\mathrm{C}(4)-\mathrm{N}(2)-\mathrm{Sc}(1)$ & $128.51(18)$ \\
\hline
\end{tabular}

\subsubsection{Reaction of $(\mathrm{LMgBr})_{2} \mathrm{ScBr}(19)$ with $\left(\mathrm{HOCH}_{2}\right)_{2} \mathrm{C}\left(\mathrm{CH}_{3}\right)_{2}$. Synthesis of $\mathrm{LMgBr}$ (21)}

The next step in providing evidence of the oxidation state of scandium in $\mathbf{1 9}$, alcohols reduction, led as it was expected to the cleavage of the sandwich molecule 19. Unfortunately only of the "protective" groups $\mathrm{LMgBr}$ could be isolated as autonomous molecule. The reaction was monitored by ${ }^{1} \mathrm{H}$ NMR spectroscopy. Because of the complexity of the reaction mixture only representative resonances were followed. The 
observations were plausible in the direction of the redox reaction, namely: the $\mathrm{HOCH}_{2}$ resonances fully disappeared from the initial position $(\delta 2.04 \mathrm{ppm})$ in the alcohol spectrum recorded in the same deuterated solvent as a sign of their reduction, and the resonance corresponding to the proton from $\mathrm{C}(\mathrm{Me}) \mathrm{CHC}(\mathrm{Me})$ position was shifted from $\delta$ $2.82 \mathrm{ppm}$ in 19 to $4.74 \mathrm{ppm}$ in the reaction mixture analogously to the resonance found for the same proton from the isolated final product $\mathrm{LMgBr}$. The characteristic resonances of $\mathrm{LMgBr}$ can be found in the final spectrum.

\subsubsection{X-ray Structural Analysis of 21}

The compound crystallizes in the monoclinic space group $P 2_{1} / c$ and it contains a molecule of toluene in the asymmetric unit that can be removed by drying.

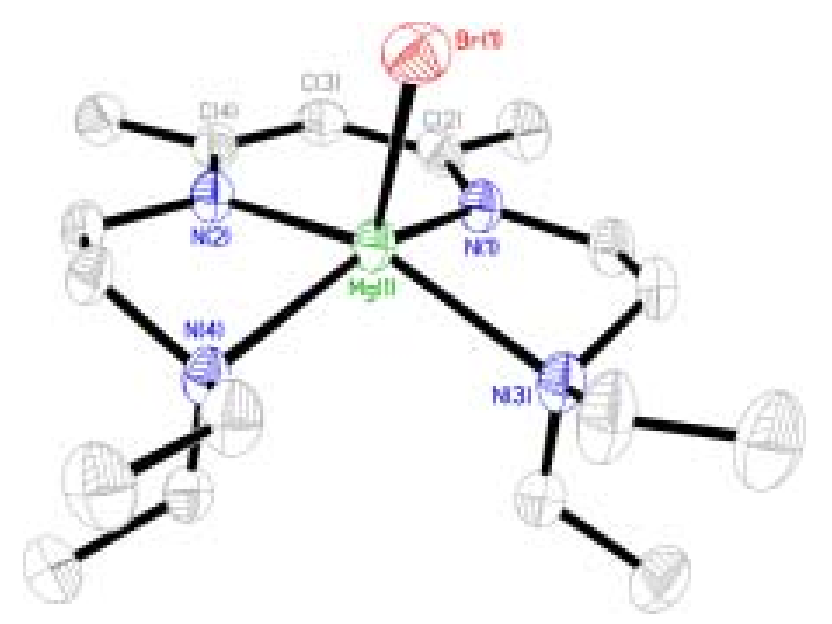

Figure 17: Molecular structure of $\mathbf{2 1}$ (50\% thermal ellipsoids probability, hydrogen atoms ommited for clarity).

Examination of the bond lengths and angles revealed by the X-ray structure of 21 facilitates the understanding of the influence of the coordination of $\mathrm{ScBr}$ to the 'ligand' $\mathrm{LMgBr}$ and it points to the retention of the $\mathrm{L}$ status (preservation of its monoanionic character) during the reaction. (See Equation 4). The pentacoordinated magnesium atom is in a pyramidal environment having $\mathrm{Mg}-\mathrm{N}$ bond distances somewhat shorter than the corresponding bond distances from 19 (Mg-N( $\beta$-diketiminato) $2.087(3) \AA ; 2.094(3) \AA$ in 21 and $2.142 \AA$ in 19; Mg-N(coordinated arms) $2.309 \AA, 2.335 \AA$ in 21 and in 19 2.345(2) $\AA$ ) attributable most likely to the higher coordination number of $\mathrm{Mg}$ in $\mathbf{1 9}$ versus 
21. These values are in accord with the literature values for $\beta$-diketiminato magnesium complexes. ${ }^{[99]}$ Interesting was the comparison of the distances and angles within the $\beta$ diketiminato backbone: $\mathrm{C}(1)-\mathrm{C}(2)$ in 19 is 1.411(3) $\AA$ and $\mathrm{C}(2)-\mathrm{C}(3)$ 1.411(5) $\AA$ and $\mathrm{C}(4)-\mathrm{C}(3)$ 1.415(5) $\AA$ in 21; C(1)-N(1) in 19 1.385(3) $\AA$ and $\mathrm{C}(2)-\mathrm{N}(1)$ in 21 1.341(5) $\AA$., the internal angle being $129.1^{\circ}$ in $\mathbf{1 9}$ and $128.03^{\circ}$ in $\mathbf{2 1}$. This closer look shows that in fact the dimensions do not change significantly to conclude that the $\mathrm{LMgBr}$ in the sandwich complex $(\mathrm{LMgBr})_{2} \mathrm{ScBr}$ is negatively charged (anion or radical-anion) and the only explanation for the slightly shorter C-N bonds in $21 v s .19$ is again the difference between the coordination sphere around $\beta$-diketiminato nitrogen atoms. (See Tables 8 and 10)

By examining the electron density plots of the three dimensional frontier molecular orbitals HOMO and LUMO of $\mathbf{2 1}$ the possibility of formation of a $\delta$ bond between the scandium and the neutral $\mathrm{LMgBr}$ units through the LUMO can be clearly seen. ${ }^{[64 \mathrm{a} 100,]}$

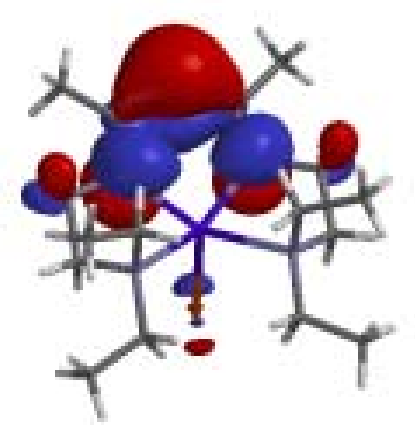

HOMO

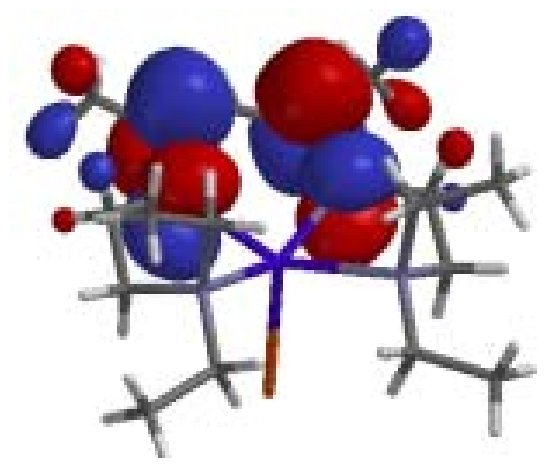

LUMO

Figure 18: 3D representations of the electronic density of the frontier orbitals HOMO and LUMO for 21.

The deviation of $\mathrm{Mg}$ from the $\mathrm{NC}_{3} \mathrm{~N}$ plane is significantly lower in $21(0.22(12)$ $\AA)$ than in 19 (1.09(4) A which can be interpreted in the bonding terms by establishing a mainly $\sigma$-type magnesium-ligand bond in the first case, but it is not necessarily a consequence of a $2 \sigma-\pi$ one in the second case. ${ }^{[64]}$ Here it seems to be more a repulsive interaction between the bromine atoms belonging to the 'ligands' and the Sc-Br unit and 
a better steric accommodation in the entire molecule. The $\mathrm{Mg}-\mathrm{Br}$ bond lengths do not differ significantly from 19 to 21 to be considered having a special behaviour (2.534(1) $\AA$ and 2.5526(12) $\AA$ ).

Table 10. Selected bond lengths $(\AA)$ and angles $\left(^{\circ}\right)$ for $\mathbf{2 1}$

\begin{tabular}{|llll|}
\hline Bond lengths & \multicolumn{3}{l|}{ Angles } \\
\hline $\mathrm{Mg}-\mathrm{N}(1)$ & $2.087(3)$ & $\mathrm{C}(2)-\mathrm{C}(3)-\mathrm{C}(4)$ & $128.0(3)$ \\
$\mathrm{Mg}-\mathrm{N}(2)$ & $2.094(3)$ & $\mathrm{N}(1)-\mathrm{Mg}-\mathrm{N}(3)$ & $79.32(11)$ \\
$\mathrm{Mg}-\mathrm{N}(3)$ & $2.309(3)$ & $\mathrm{N}(1)-\mathrm{Mg}-\mathrm{N}(2)$ & $88.22(12)$ \\
$\mathrm{Mg}-\mathrm{N}(4)$ & $2.335(3)$ & $\mathrm{N}(2)-\mathrm{Mg}-\mathrm{N}(4)$ & $78.87(11)$ \\
$\mathrm{C}(1)-\mathrm{C}(2)$ & $1.532(5)$ & $\mathrm{N}(3)-\mathrm{Mg}-\mathrm{N}(4)$ & $99.29(11)$ \\
$\mathrm{C}(2)-\mathrm{C}(3)$ & $1.411(5)$ & & \\
$\mathrm{C}(2)-\mathrm{N}(1)$ & $1.341(5)$ & & \\
$\mathrm{C}(4)-\mathrm{N}(2)$ & $1.334(5)$ & & \\
$\mathrm{Mg}(1)-\mathrm{Br}(1)$ & $2.5526(12)$ & & \\
\hline
\end{tabular}

\subsubsection{Synthesis of Cluster $\mathrm{Lu}_{2} \mathrm{Mg}_{4} \mathrm{Cl}_{10} \mathrm{O}_{2} \cdot 6 \mathrm{THF}$ (22)}

A realistic target after synthesis of the scandium(I) complex was a homologous complex with lutetium. The reason of choosing lutetium was that it is the closest in size in the rare earth elements row after scandium $(0.88 \AA)$ with a radius of $1.00 \AA$. The reaction between $\mathrm{LLuCl}_{2}(\mathbf{9})$ and allyl magnesium chloride under the same conditions as in the scandium case occurred with formation of a product completely different to the previous one. The native yellow-orange THF solution kept its color after $1 \mathrm{~d}$ of reaction but the extract in toluene proved to be light green. But the green color of the toluene solution disappeared even under rigorous exclusion of water and air after several hours. The resulting solution was further concentrated, few drops of THF were added, and kept at $-26{ }^{\circ} \mathrm{C}$. After one-week crystals of $\mathbf{2 2}$ precipitated in a very low yield.

$$
\mathrm{LLuCl}_{2}+2 \rightleftharpoons \mathrm{MgCl} \longrightarrow \mathbf{2 2}+\text { unidentified products }
$$

\section{9}

Equation 8

Taking into account the precedent reaction and the short appearance of the green color not specifically for a lutetium( $(+3)$ ion, a pathway involving formation of a unstable 
lutetium(I) species similar to scandium could be assumed. The instability of this species can be explained by both the larger radius of lutetium in comparison to scandium and the smaller radius of chlorine in comparison to bromine. A consequence is the propensity of lutetium for higher coordination numbers than scandium resulting in an insufficient protection for a formal $\mathrm{Lu}(+1) \mathrm{Cl}$ molecule offered by the $\mathrm{LMgCl}$ molecules (opposite to that in 19). Nonetheless, apart from the sterical aspect of the problem, indisputably the different electronic configuration of lutetium determines its behavior in comparison to scandium requesting stronger $\pi$ donors. The intermediate species formed is very reactive and attacks the THF molecules under oxidation and formation of a stable cluster that does not contain the ligand L. This way of stabilization is rather common in rare earth metals chemistry. ${ }^{[101]}$ Clusters of the type described below were reported for lanthanum and praseodymium. ${ }^{[102 \mathrm{a}]}$

\subsubsection{X-ray Structural Analysis of 22}

Once the NMR spectra display only resonances characteristic for THF molecules, the single crystal X-ray structural analysis revealed the structure of compound 22, as showed in Figure 19.

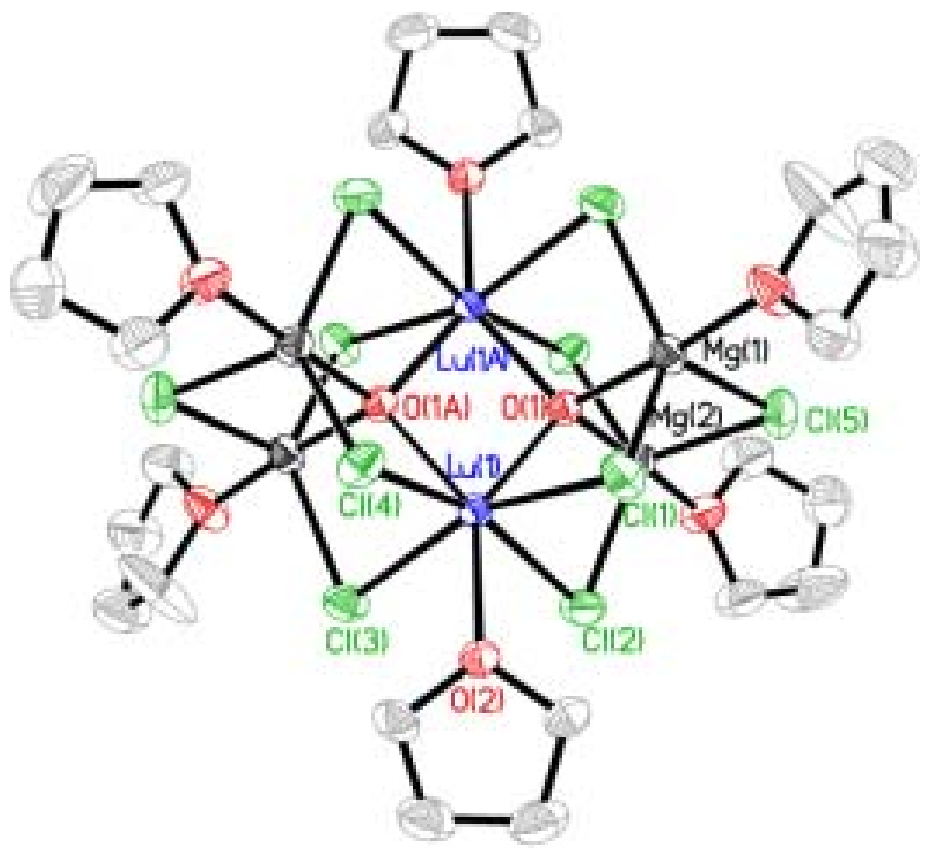

Figure 19: Molecular Structure of 22 (50\% thermal ellipsoids probability, hydrogen atoms ommited for clarity); There can be observed two THF molecules disordered. 
Compound 22 crystallizes in the centrosymmetric triclinic space group $P \overline{1}$ with half of molecule in the asymmetric unit. The molecule itself is quite symmetrical and discloses several interesting features.
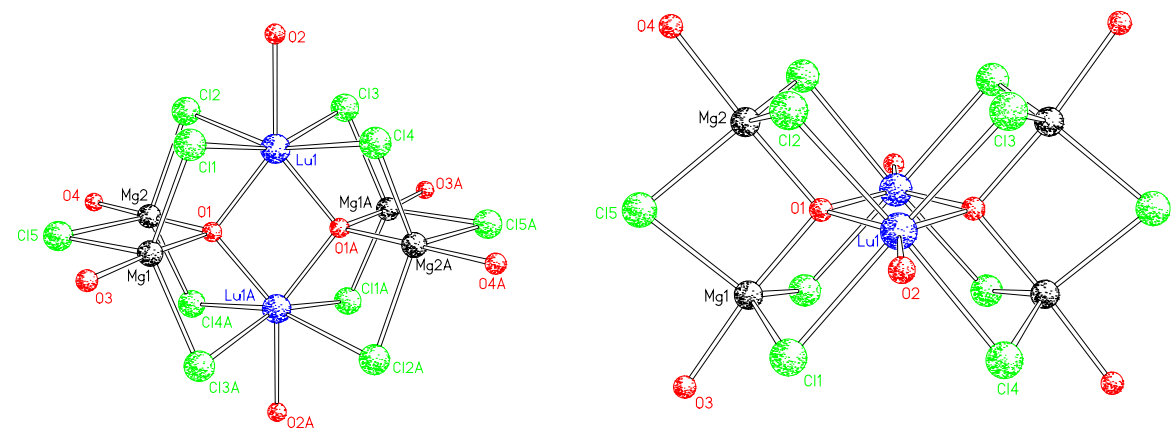

Figure 20: Core of $\mathbf{2 2}$ from two different perspectives.

The lutetium atom is heptacoordinated, this coordination number is rather rare for lanthanides but in this case it is compensated by the cluster formation. The central ring formed by the two lutetium atoms and the two oxygen atoms which probably originate from THF molecules, is perfectly planar (see Figure 20). Perpendicular to this plane are located other two rings formed by $\mathrm{Mg}(1), \mathrm{O}(1), \mathrm{Mg}(2), \mathrm{Cl}(5)$ and their symmetry related atoms.

Table 11. Selected bond lengths $(\AA)$ and angles $\left(^{\circ}\right)$ for 22

\begin{tabular}{|llll|}
\hline Bond lengths & \multicolumn{3}{l|}{ Angles } \\
\hline $\mathrm{Lu}(1)-\mathrm{O}(1)$ & $2.171(2)$ & $\mathrm{Mg}(1)-\mathrm{Cl}(1)-\mathrm{Lu}(1)$ & $85.17(5)$ \\
$\mathrm{Lu}(1)-\mathrm{Cl}(1)$ & $2.7278(11)$ & $\mathrm{Mg}(2)-\mathrm{Cl}(2)-\mathrm{Lu}(1)$ & $84.75(4)$ \\
$\mathrm{Lu}(1)-\mathrm{Cl}(2)$ & $2.7389(14)$ & $\mathrm{Mg}(1)-\mathrm{O}(1)-\mathrm{Mg}(2)$ & $100.22(10)$ \\
$\mathrm{Lu}(1)-\mathrm{Cl}(3)$ & $2.7131(12)$ & $\mathrm{Mg}(1)-\mathrm{Cl}(5)-\mathrm{Mg}(2)$ & $79.10(5)$ \\
$\mathrm{Lu}(1)-\mathrm{Cl}(4)$ & $2.7201(12)$ & $\mathrm{O}(1)-\mathrm{Lu}(1)-\mathrm{O}(1 \mathrm{~A})$ & $75.47(8)$ \\
$\mathrm{Lu}(1)-\mathrm{Lu}(1 \mathrm{~A})$ & $3.4340(13)$ & $\mathrm{Lu}(1)-\mathrm{O}(1)-\mathrm{Lu}(1 \mathrm{~A})$ & $104.53(8)$ \\
$\mathrm{Mg}(1)-\mathrm{Cl}(5)$ & $2.4114(16)$ & $\mathrm{Mg}(1)-\mathrm{O}(1)-\mathrm{Mg}(2)$ & $100.22(10)$ \\
$\mathrm{Mg}(2)-\mathrm{Cl}(5)$ & $2.4149(15)$ & $\mathrm{O}(1)-\mathrm{Mg}(2)-\mathrm{Cl}(5)$ & $90.20(7)$ \\
$\mathrm{Cl}(1)-\mathrm{Mg}(1)$ & $2.4114(14)$ & $\mathrm{O}(1)-\mathrm{Mg}(1)-\mathrm{O}(3)$ & $174.46(11)$ \\
$\mathrm{Cl}(2)-\mathrm{Mg}(2)$ & $2.4136(14)$ & & \\
$\mathrm{O}(1)-\mathrm{Mg}(1)$ & $1.999(2)$ & & \\
$\mathrm{Mg}(1)-\mathrm{O}(3)$ & $2.057(3)$ & & \\
\hline
\end{tabular}


The magnesium atoms are pentacoordinated with a trigonal-bypiramidal geometry $\left(\mathrm{O}(1)-\mathrm{Mg}(2)-\mathrm{O}(4) \quad 177.15(11)^{\circ} \text { and } \mathrm{O}(1)-\mathrm{Mg}(1)-\mathrm{O}(3) \text { 174.46(11) }\right)^{\circ}$. The $\mathrm{Mg}-\mathrm{Cl}$ bond lengths are in the range of reported compounds with these types of bonds (terminal and bridges). ${ }^{[103]}$ The Lu-Cl distances do not differ too much of distances in compounds with approximately the same coordination. ${ }^{[104]}$ The Lu-Lu distance is 3.4340(13) A, and it can be compared with reported bond lengths for several compounds in the solid-state chemistry. ${ }^{[35,102]}$

\subsubsection{Synthesis of adducts $(\mathrm{LLi})_{2} \mathrm{SmI}_{2}(23)$ and $\left(\mathrm{LLi}_{2}\right)_{2} \mathrm{YbI}_{2}(24)$}

The chemistry of well-defined divalent lanthanides complexes of $\mathrm{Sm}, \mathrm{Eu}$, and $\mathrm{Yb}$, was developed in the last two decades with the general tendency of diminishing the influence of the cyclopentadienyl ligands. Progress has been achieved in synthesis of the alkyl derivatives of these species for catalytically purposes. ${ }^{[105]}$ The halogeno complexes can be used as well for further reductions as method for the synthesis of compounds in oxidation states +1 or 0 . Some apparently subvalent samarium and ytterbium complexes with $\beta$-diketiminato ligands have been prepared by Lappert et al. ${ }^{[59,106]}$

When the ligand $\mathrm{L}^{-}$was involved, attempts to obtain an iodo derivative of $\mathrm{Sm}^{2+}$, and an alkyl derivative of $\mathrm{Yb}^{2+}$ led to the synthesis of compounds $\mathbf{2 3}$ and $\mathbf{2 4}$ as adducts of the diiodo derivatives with two molecules of the lithium salt of the ligand. In the reaction between anhydrous $\mathrm{SmI}_{2}$ and lithium salt of the ligand in toluene, even at reflux temperature, substitution of the iodine did not take place, instead, the $\pi$-donor ability of the ligand manifests by forming compound 23 .

Equation 9

$$
2 \mathrm{LLi}+\mathrm{SmI}_{2} \longrightarrow(\mathrm{LLi})_{2} \mathrm{SmI}_{2}
$$

It has been shown that the Grignard analogues of ytterbium and samarium are useful reagents for the synthesis of organocomplexes of these elements. ${ }^{[8]}$ In the reaction between neopentyl iodide and ytterbium metal, the in situ formation of such compound was intended ${ }^{[107]}$ for further reaction with the lithium salt of the ligand under final formation of (neopentyl)YbL. As a consequence of a Schlenk-like equilibrium shown in 
Equation $10,{ }^{[108]}$ which produces $\mathrm{YbI}_{2}$, the product of this reaction in THF was a similar complex as in the samarium case, $(\mathrm{LLi})_{2} \mathrm{YbI}_{2}(\mathbf{2 4})$.

Equation 10

$2 \mathrm{RYbI} \rightleftharpoons \mathrm{R}_{2} \mathrm{Yb}+\mathrm{YbI}_{2}$

In both compounds the $\mathrm{Cp}$ like coordinated ligands satisfy the steric demands and the Lewis acidity of the lanthanides, so no coordinating solvent molecule is involved (at least in the second case where THF is involved in the reaction).

The MS spectra of these compounds can be misleading since they show peaks assignable to the LLnI fragments. The resonaces in the ${ }^{1} \mathrm{H}$ NMR spectrum of $\mathbf{2 3}$, although relatively sharp, are strongly shifted due to the paramagnetism of the metals.

\subsubsection{X-ray Structural Analysis of 23 and 24}

The two compounds crystallize isostructural in the monoclinic space group $C 2$, the asymmetric unit contains two chemically equivalent, crystallographically independent halves of molecules and a toluene molecule. Each of the Ln atoms lies on the two-fold axis. The molecular structure of $\mathbf{2 4}$ is depicted in Figure 21.

The coordination mode of the two LLi molecules is antiperiplanar, with an angle between the two planes averaging $35^{\circ}(\mathbf{2 3})$ and $31^{\circ}(\mathbf{2 4})$, surrounding $\mathrm{Sm}$ and $\mathrm{Yb}$, respectively, that are 12-coordinated (the maximal coordination number for the rare earth metals). The distances Ln-NCCCN(centroid) are averaging $2.45 \AA$ (23) and $2.35 \AA$ (24), are slightly shorter than the corresponding distances for the cyclopentadienyl compounds of these metals ${ }^{[44 \mathrm{~b}, 47 \mathrm{c}, 70]}$ obviously because of the pure donor type interaction present between the metals and the neutral LLi ligands. Complexes 23 and $\mathbf{2 4}$ are examples that support the ability of the salts of $\mathrm{L}$ to act as neutral ligands as in the case of compound 19. The lithium atoms are $\sigma$-bonded to the backbone (the mean deviations Li-NCCCN plane are 0.63 and $0.60 \AA$, respectively). The Sm-I and Yb-I distances are within the quite large range of previously reported examples depending on many factors like donor ability of the ligand, coordination number and type of bonding (terminal or bridge). The mean distances Ln- $\beta$-diketiminato backbone are $2.81 \AA$ (23) and $2.76 \AA$ (24), respectively. The bond lengths and angles inside the $\beta$-diketiminato backbone differ not 
significantly in comparison to the free lithium salt. Important bond and angles are presented in Table 12. In brackets are presented the values for the corresponding bond lengths and angles of the second molecule of compound in the unit cell.

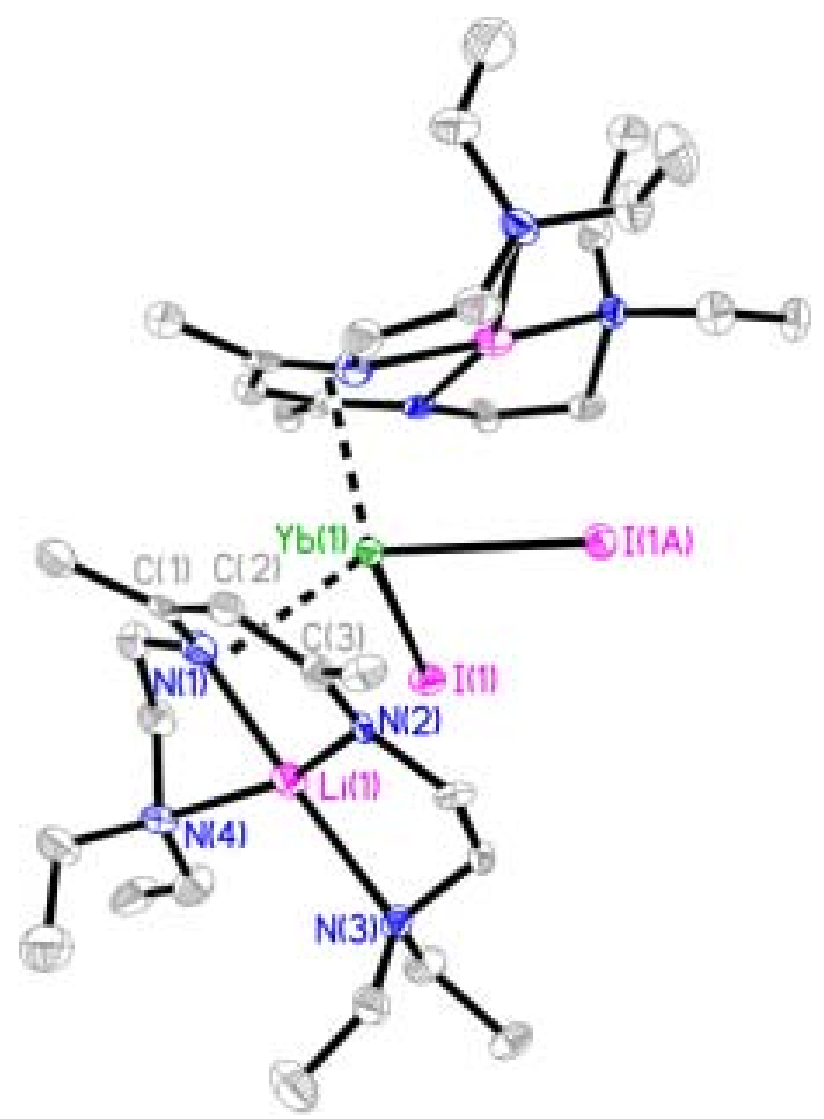

Figure 21: Molecular structure of $\mathbf{2 4}$ (50\% thermal ellipsoids probability, hydrogen atoms and toluene molecule ommited for clarity). 
Table 12. Selected bond lengths $(\AA)$ and angles $\left({ }^{\circ}\right)$ for the compounds 23 and $\mathbf{2 4}$ (Symmetry transformations used to generate equivalent atoms: A - $\mathrm{x}+1, \mathrm{y},-\mathrm{z}+1 ; \mathrm{B}-\mathrm{x}, \mathrm{y},-\mathrm{z}+2$ )

\begin{tabular}{|lll|}
\hline Bond lengths & $\mathbf{2 4}$ & $\mathbf{2 3}$ \\
\hline Ln(1)-N(1) & $2.600(6)[2.605(6)]$ & $2.723(6)[2.728(6)]$ \\
Ln(1)-N(2) & $2.640(6)[2.622(6)]$ & $2.735(5)[2.751(5)]$ \\
Ln(1)-C(1) & $2.909(8)[2.880(8)]$ & $2.901(5)[2.908(6)]$ \\
Ln(1)-C(2) & $2.845(9)[2.814(8)]$ & $2.960(7)[2.930(5)]$ \\
Ln(1)-C(3) & $2.848(8)[2.832(9)]$ & $2.880(6)[2.963(6)]$ \\
Ln(1)-I(1) & $3.1595(11)[3.1662(12)]$ & $3.2525(10)[3.2478(10)]$ \\
$\mathrm{N}(3)-\operatorname{Li}(1)$ & $2.385(16)[2.282(13)]$ & $2.292(11)[2.386(11)]$ \\
$\mathrm{N}(2)-\operatorname{Li}(1)$ & $2.082(13)[2.102(13)]$ & $2.079(12)[2.096(13)]$ \\
$\mathrm{N}(1)-\mathrm{Li}(1)$ & $2.133(16)[2.125(15)]$ & $2.097(14)[2.096(15)]$ \\
$\mathrm{N}(4)-\operatorname{Li}(1)$ & $2.356(13)[2.265(15)]$ & $2.257(15)[2.329(15)]$ \\
\hline Angles & & \\
\hline I(1A)-Yb(1)-I(1) & $93.53(4)[92.51(4)]$ & $94.60(4)[94.98(3)]$ \\
C(1)-C(2)-C(3) & 128.6(7) $126.8(8)$ & $129.3(7)[127.7(7)]$ \\
\hline
\end{tabular}




\section{SUMMARY AND CONCLUSIONS}

\subsection{Summary}

As indicated in Section 1.1. one of the aims of this work was to synthesize and characterize dihalogeno derivatives of the rare earth metals with the monoanionic ligand $\mathrm{L}\left(\mathrm{L}=\mathrm{Et}_{2} \mathrm{NCH}_{2} \mathrm{CH}_{2} \mathrm{NC}(\mathrm{Me}) \mathrm{CHC}(\mathrm{Me}) \mathrm{NCH}_{2} \mathrm{CH}_{2} \mathrm{NEt}_{2}\right)$ free of coordinating solvent molecules or alkalimetal salts. For the smallest rare earth elements scandium, yttrium, and lutetium the 1:1 metathesis reaction between the lithium or potassium salts of the ligand and $\mathrm{LnX}_{3}(\mathrm{Ln}=\mathrm{Sc}, \mathrm{Y}, \mathrm{Lu} ; \mathrm{X}=\mathrm{Cl}, \mathrm{Br}, \mathrm{I})$ led to the expected results namely the synthesis of compounds of the type $\mathrm{LLnX}_{2}$ with the properties above mentioned.

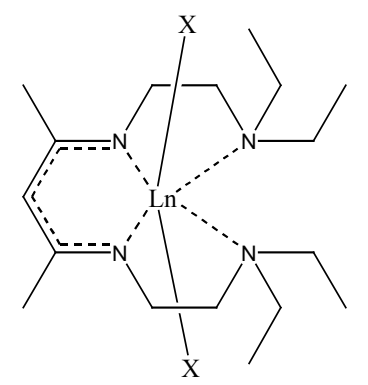
5: $\mathrm{Ln}=\mathrm{Sc} ; \mathrm{X}=\mathrm{Cl}$
8: $\mathrm{Ln}=\mathrm{Y} ; \mathrm{X}=\mathrm{Br}$
6: $\mathrm{Ln}=\mathrm{Sc} ; \mathrm{X}=\mathrm{Br}$
9: $\mathrm{Ln}=\mathrm{Lu} ; \mathrm{X}=\mathrm{Cl}$
7: $\mathrm{Ln}=\mathrm{Y} ; \mathrm{X}=\mathrm{Cl}$
10: $\mathrm{Ln}=\mathrm{Sc} ; \mathrm{X}=\mathrm{I}$
11: $\operatorname{Ln}=\mathrm{Y} ; \mathrm{X}=\mathrm{I}$

Compounds 5, 6, and 8 have been characterized by single crystal X-ray crystallography and they have in common a pseudooctahedral geometry with the halogen atoms in the axial positions.

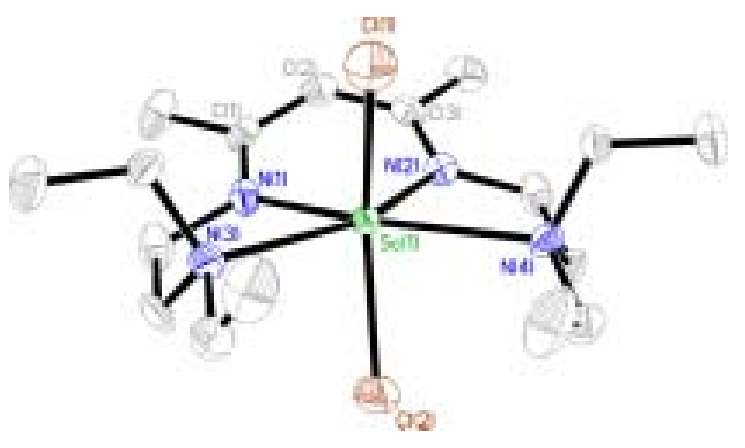

Structure of 5 
The interest in this kind of compounds was their use as possible starting materials for reductions with the aim of obtaining rare earth complexes in low oxidation states of the metal, and also for studying their involvement in different metathesis reactions. 7, 8 and $\mathbf{1 1}$ are the first examples of $\beta$-diketiminato compounds of yttrium.

Due to the larger radius of the metal, e.g. for lanthanum and cerium, are obtained adducts of the expected $\mathrm{LLnCl}_{2}(\mathrm{Ln}=\mathrm{La}, \mathrm{Ce})$ and the lithium salt (12 and 13). These complexes are better soluble than the uncomplexed counterparts due to the additional coordinated salt. For lanthanum, $\mathbf{1 2}$ is the first $\beta$-diketiminato complex.

Structure of $\mathbf{1 2}$

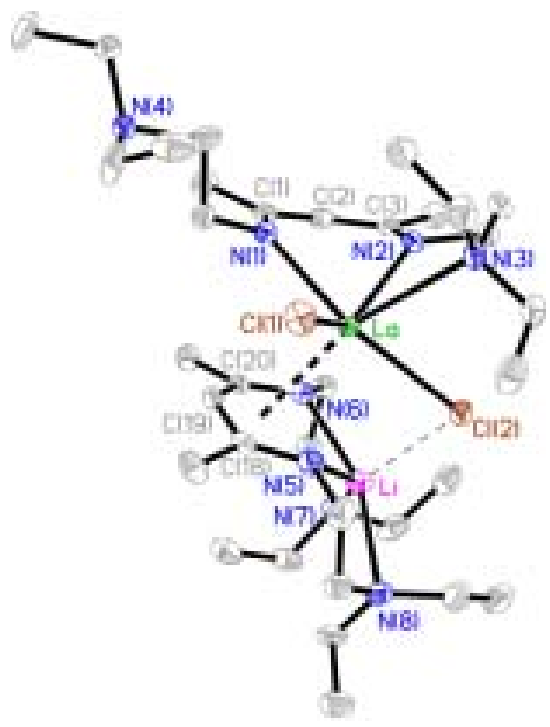

Studies of the complexes described above were focused in exploring the reactivity of the scandium complexes as a consequence of the interest in the versatility of this metal. Metathesis reactions on the scandium center in the ligand $\mathrm{L}^{-}$surrounding proved not to proceed along desired pathway when alkyl lithium or Grignard reagents where involved. The role of the ligand in the metathesis reaction with this kind of reagents, although not clear, is important. This has been proven by the synthesis of dialkyls of scandium with another $\beta$-diketiminato ligand. ${ }^{[62]}$

As an alternative reagent $\mathrm{NaN}\left(\mathrm{SiMe}_{3}\right)_{2}$ was used. Instead of a disubstituted complex $\mathrm{LSc}\left(\mathrm{N}\left(\mathrm{SiMe}_{3}\right)_{2}\right)_{2}$ in the reaction between 5 (and also 6) with $\mathrm{NaN}\left(\mathrm{SiMe}_{3}\right)_{2}$ one of the $\mathrm{C}-\mathrm{H}$ bond of the methyl group belonging to the $\beta$-diketiminato backbone of the 
ligand is 'activated' and resulting in a dinuclear scandium complex with a polycyclic structure.

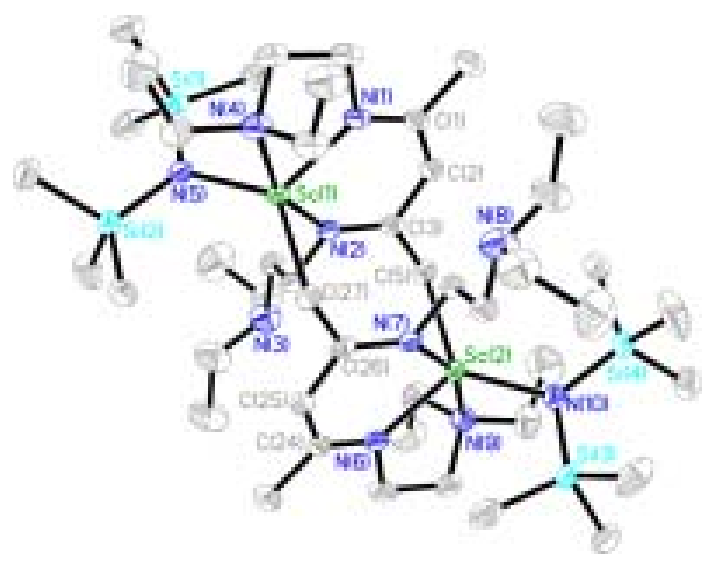

\section{Structure of $\mathbf{1 4}$}

Two mechanisms for the formation of $\mathbf{1 4}$ have been proposed.

Metathesis reactions were investigated with the scandium complexes 5 and $\mathbf{6}$ by reaction with $\mathrm{AgSO}_{3} \mathrm{CF}_{3}$ (1:2) where the expected disubstituted derivative was formed. 15 can serve as a further starting material for other substitution reactions and deserves to be further screened for catalysis reactions. Attempted disubstitution with $\mathrm{Me}_{3} \mathrm{SnF}$ resulted in both cases (5 and $\mathbf{6}$ ) in compounds with Sc-F bonds but as trinuclear species incorporating $\mathrm{SnMe}_{3} \mathrm{Cl}$ and $\mathrm{SnMe}_{3} \mathrm{Br}$ moieties, respectively.

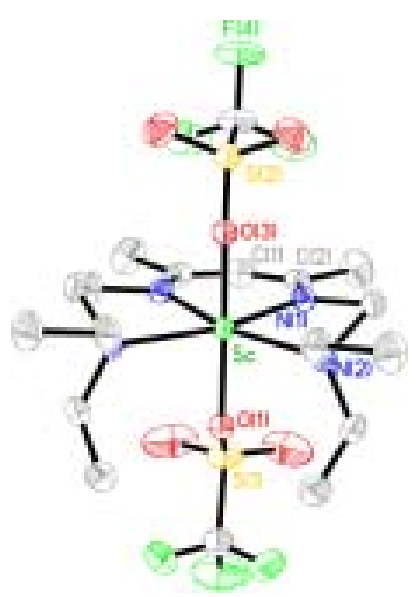

Structure of $\mathbf{1 5}$

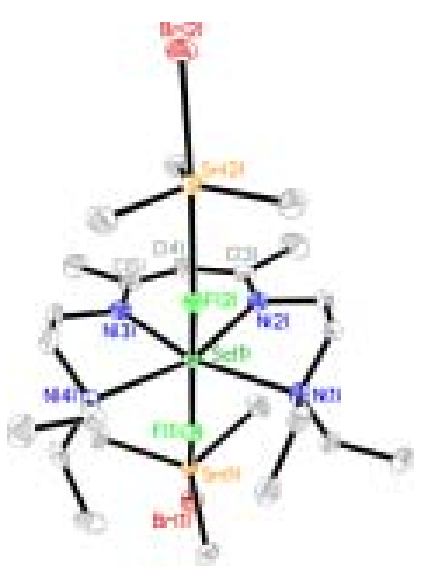

Structure of 17 
An attempt to obtain a compound similar to $\mathbf{1 4}$ was done under analogous reaction conditions. It resulted in very low yield in compound $\mathbf{1 8}$ also as a dimer but this time the reaction was directed by the $\mathrm{N}\left(\mathrm{SiMe}_{3}\right)_{2}$ groups probably with elimination of $\mathrm{SiMe}_{4}$ and further rearrangements. X-ray structure analysis evidenced a polycyclic molecule with the two yttrium atoms connected through imido bridges. 18 could not be characterized by NMR and elemental analysis.

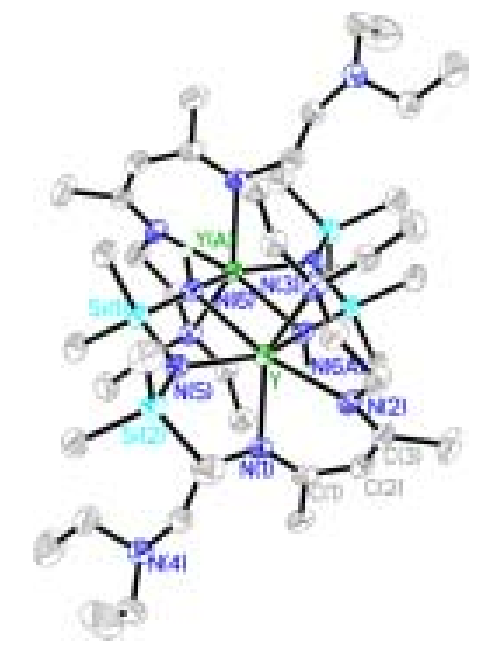

Structure of 18

A main objective of this work was to synthesize a molecular scandium(I) compound in solution. Although the classical reductive methods of the dihalogeno compounds of scandium were unsuccessful, the reaction of $\mathrm{LScBr}_{2}$ with allyl magnesium bromide led to a dark blue compound that was identified as containing a $\mathrm{Sc}(\mathrm{I}) \mathrm{Br}$ molecule surrounded by two $\mathrm{LMgBr}$ units. The reducing agent in this reaction proved to be allyl magnesium bromide, as evidenced by 1,5-hexadiene as the only volatile byproduct. 
Structure of 19

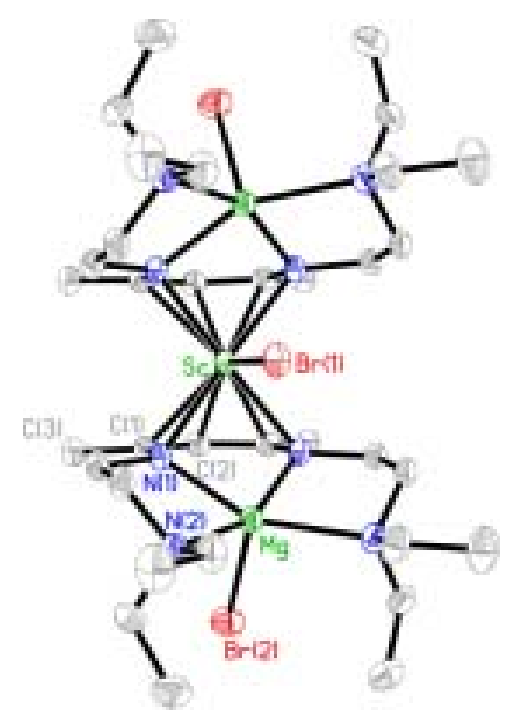

The most prominent feature of this compound is, besides its synthesis in solution, the electronic configuration of scandium. NMR, EPR, and magnetic measurements employed to characterize 19 indicated that it is diamagnetic. Theoretical calculations revealed that the electrons responsible for the magnetic behavior are located in a Sc $\mathrm{d}_{x y}$ orbital and a small degree of stabilization of this compound through $\delta$-backbonding to the two heterocyclic rings sandwiching the scandium atom.

Further evidence of the oxidation state of scandium in $\mathbf{1 9}$ was gained by involvement in a redox reaction with $\mathrm{H}_{2} \mathrm{O} \cdot \mathrm{B}\left(\mathrm{C}_{6} \mathrm{~F}_{5}\right)_{3}$ where $\mathrm{H}_{2} \mathrm{O}$ was reduced and scandium was oxidized to the oxidation state +3 leading to compound $\mathbf{2 0}$ under abstraction of one $\mathrm{C}_{6} \mathrm{~F}_{5}$ group from each boron atom. Via GC-MS analysis $\mathrm{C}_{6} \mathrm{~F}_{5} \mathrm{H}$ was found among the reaction products.

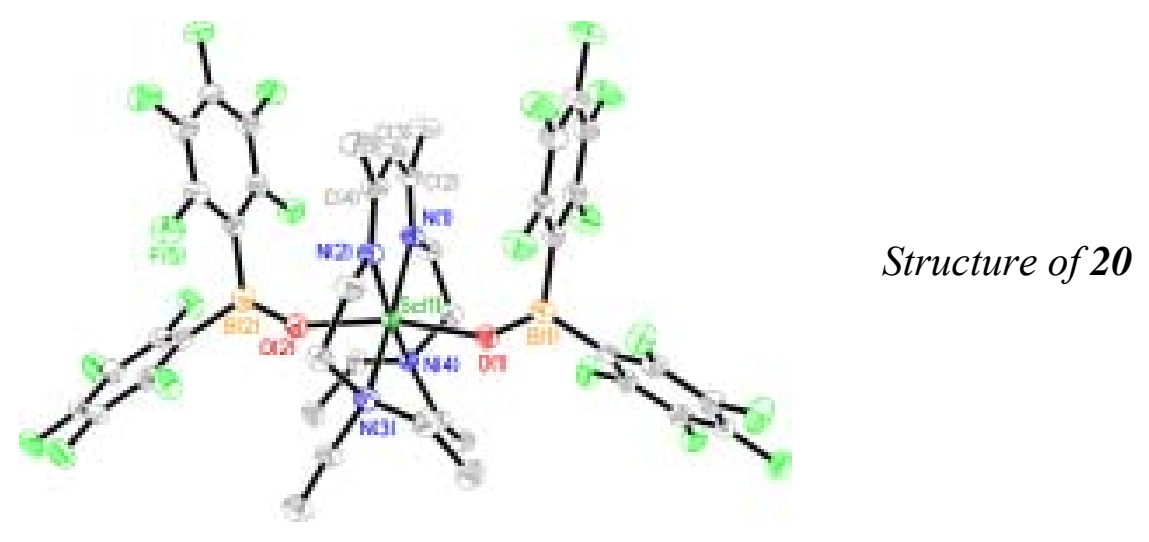


To further elucidate the nature of the bonding and the oxidation state of scandium in 19, it was reacted with a hindered diol with no $\beta$-protons $\left(\mathrm{HOCH}_{2}\right)_{2} \mathrm{C}\left(\mathrm{CH}_{3}\right)_{2}$ leading to the isolation of neutral $\mathrm{LMgBr}$ (21). It shows no significant differences in bonding parameters compared to the same unit in 19. Another theoretical study showed indeed the possibility of the $\delta$ bond formation

The reaction of $\mathrm{LLuCl}_{2}$ with allylMgBr under conditions similar to the synthesis of 19 resulted in complete abstraction of the ligand leaving hexanuclear $\mathrm{Lu}_{2} \mathrm{Mg}_{4}$ core 22 in low yields. The oxygen stems from cleavage of THF as already observed earlier with aluminum. ${ }^{[109]}$ The product was complex 22 as a consequence probably of the differences, small but essential for the case, between scandium and lutetium and chlorine and bromine. An intermediate similar to $\mathbf{1 9}$ was proposed which is not stable and very reactive.

Structure of 22

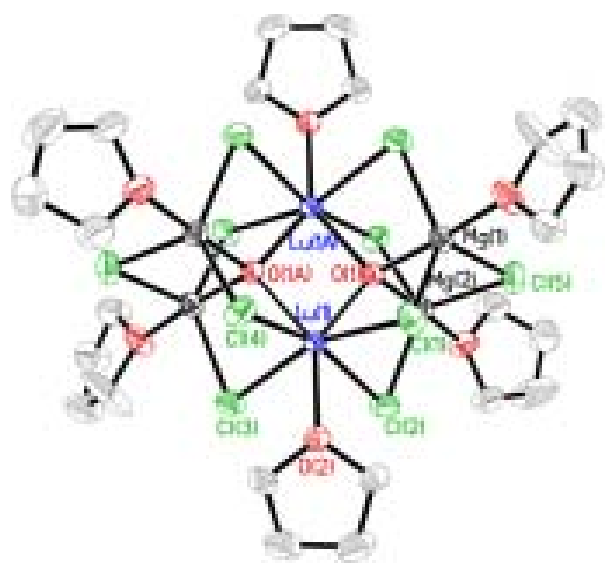

From the point of view of the applications in catalysis and organic synthesis the compounds of rare earth metals in stable low oxidation states play a very important role. Attempts to obtain a substituted SmI species with the ligand L and an organo complex LYbR via RYbI (as a Grignard reagent) resulted in adduct formations. In the first case in the reaction with $\mathrm{SmI}_{2}$, the lithium salt acted only as donor, and in the second case, due to the Schlenk equilibrium present in solution, $\mathrm{YbI}_{2}$ was formed and the adduct formation as in the samarium case took place. 


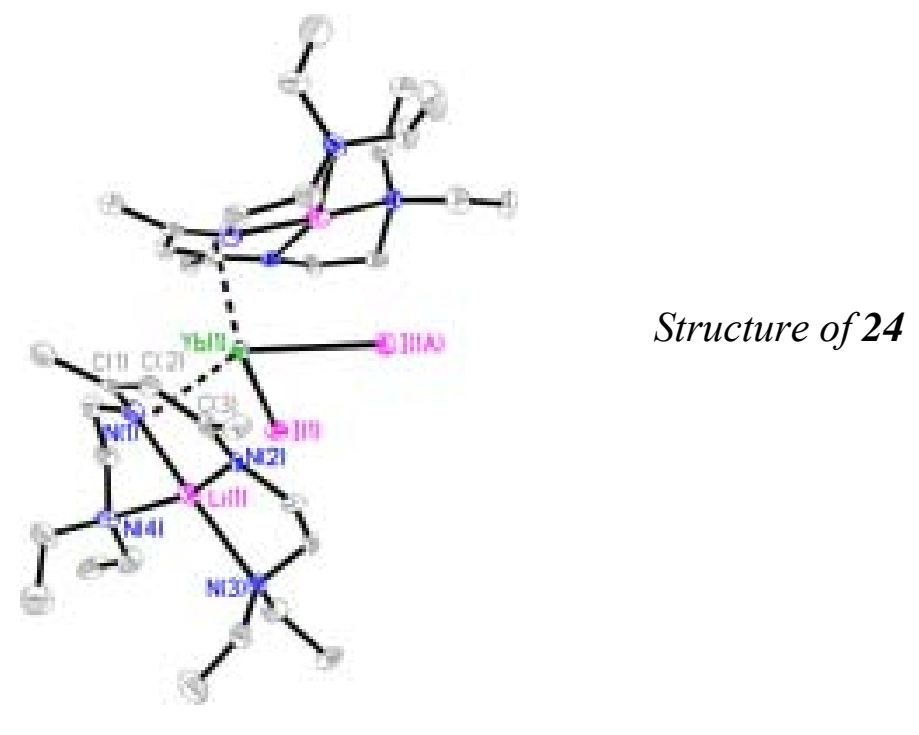

\subsection{Conclusions}

In this work complexes of the rare earth metals, scandium, yttrium, lanthanum, cerium, and lutetium with a $\beta$-diketiminato ligand were synthesized and investigated, focused mainly on scandium chemistry. The products are solvent and alkali salt free, reason for which they may show potential as precursors for catalytically active materials and they can be involved in interesting syntheses of compounds with atypical properties (e.g. extreme oxidation states). Reports about monoanionic, non-cyclopentadienyl, dihalogeno complexes of these metals are rare. The non-conventional method which led to the synthesis of the scandium $(+1)$ complex in solution may be extended to other rare earth elements with the prerequisite of tailoring the appropriate rare earth precursors and reductive agents. 


\section{Experimental Section}

\subsection{General Procedures}

All manipulations were performed on a high-vacuum line or in a glove box under a purified $\mathrm{N}_{2}$ atmosphere, using Schlenk techniques with rigorous exclusion of moisture and air. All the necessary glassware was oven-dried at $150{ }^{\circ} \mathrm{C}$ for a minimum period of $12 \mathrm{~h}$, assembled hot and cooled under high vacuum with intermittent flushing of nitrogen or argon. The samples for spectral measurements were prepared inside a MBraun MB 150-GI glove-box where the $\mathrm{O}_{2}$ and $\mathrm{H}_{2} \mathrm{O}$ levels were normally maintained below $1 \mathrm{ppm}$. Commercial grade solvents were purified and freshly distilled following conventional procedures prior to their use. ${ }^{[110]}$

\subsection{Physical Measurements}

${ }^{1} \mathrm{H},{ }^{13} \mathrm{C},{ }^{19} \mathrm{~F},{ }^{45} \mathrm{Sc}$, and ${ }^{29} \mathrm{Si}$ NMR spectra $\left(\mathrm{C}_{6} \mathrm{D}_{6}\right.$, Toluene- $\left.d_{8}, \mathrm{THF}-d_{8}, \mathrm{CDCl}_{3}\right)$ were recorded on Bruker MSL-400, AM-250 and Avance-200 instruments. The chemical shifts are reported in ppm with reference to external standards more explicitly, $\mathrm{SiMe}_{4}$ for ${ }^{1} \mathrm{H}$, ${ }^{13} \mathrm{C}$, and ${ }^{29} \mathrm{Si}$ nuclei, $\mathrm{C}_{6} \mathrm{~F}_{6} / \mathrm{CFCl}_{3}$ for ${ }^{19} \mathrm{~F}$ nucleus, $\left[\mathrm{Sc}\left(\mathrm{H}_{2} \mathrm{O}\right)_{6}\right]^{3+} / \mathrm{D}_{2} \mathrm{O}$ for ${ }^{45} \mathrm{Sc}$ nucleus, $\mathrm{LiCl} / \mathrm{D}_{2} \mathrm{O}$ for ${ }^{7} \mathrm{Li}$ nucleus. Solid-state ${ }^{45} \mathrm{Sc}$ and ${ }^{13} \mathrm{C}$ NMR spectra were recorded on a Bruker A-600. The ${ }^{45} \mathrm{Sc}$ solid state NMR spectra experiments were conducted at 600 $\mathrm{MHz}$ ( ${ }^{1} \mathrm{H}$ resonance frequency) employing $4 \mathrm{~mm}$ triple-resonance MAS probeheads. All heteroatom NMR spectra were measured in the ${ }^{1} \mathrm{H}$ decoupled mode. The solvents for NMR measurements were dried over $\mathrm{K}$ or $\mathrm{CaH}_{2}$ and trap-to-trap distilled prior to use.

Melting points of all new compounds were measured in sealed capillaries on a Büchi B 540 instrument.

Mass spectra were obtained on a Finnigan MAT 8230 Spectrometer by EI technique. Only the most abundant peak of any isotope distribution is given. 
EPR spectra were recorded on a Varian Century-Line $9 \mathrm{GHz}$ Spectrometer.

The UV-vis Spectrum was recorded on a Perkin Elmer 320 Spectrometer.

Magnetic measurements were performed on a Squid-Magnetometer (Fa. Quantum Design, California) at different magnetic fields in the range of temperatures between 2 and $300 \mathrm{~K}$.

Elemental analyses were performed at the Analytisches Labor des Instituts für Anorganische Chemie der Universität Göttingen.

Crystal structure determination: Intensity data for compounds $\mathbf{5}, \mathbf{6}, \mathbf{7}, \mathbf{1 2}, \mathbf{1 3}, \mathbf{1 4}, \mathbf{1 5}, \mathbf{1 6}$, 18, 19, 23, and 24 were collected on a Stoe Image Plate IPDS II-System, for compound 20 on a SMART 6000 diffractometer, for compounds 17a and 17b on a Stoe/Huber/Siemens four-circle diffractometer and for compounds $\mathbf{2 1}$ and $\mathbf{2 2}$ on a Bruker Smart Apex CCD diffractometer. The data for all the compounds were collected at low temperature (the temperatures for individual compounds are mentioned in the tables in Section 6) using graphite monochromated Mo $\mathrm{K}_{\alpha}$ radiation $(\lambda=0.71073 \AA)$ or $\mathrm{Cu} \mathrm{K}_{\alpha}$ radiation $(\lambda=1.54178)$ (for 20). The data reduction and space group determination were carried out using Bruker family of programs. ${ }^{[111]}$ The structures were solved by direct methods (SHELX-97) and refined against $F^{2}$ using SHELXL-97. ${ }^{[112]} \mathrm{R}$ values were defined as $R_{1}=\Sigma|| F_{\mathrm{o}}|-| F_{\mathrm{c}}|/ / \Sigma| F_{\mathrm{o}} \mid, \mathrm{w} R_{2}=\left[\Sigma w\left(F_{\mathrm{o}}{ }^{2}-F_{\mathrm{c}}{ }^{2}\right)^{2} / \Sigma w\left(F_{\mathrm{o}}{ }^{2}\right)^{2}\right]^{0.5}, w=\left[\sigma^{2}\left(F_{\mathrm{o}}{ }^{2}\right)+\left(g_{1} P\right)^{2}+\right.$ $\left.g_{2} P\right]^{-1}, P=1 / 3\left[\max \left(F_{\mathrm{o}}^{2}, 0\right)+2 F_{\mathrm{c}}^{2}\right]$. For the crystal structure of 20 as non-merohedric twin were determined the two matrices of the two domains and every domain was integrated on its own. Then a new file with the reflections of the dominant domain was written, without reflections that were strongly overlapped with reflections of the other domain. With these data the structure was solved and refined. For the racemic twinned compounds $\mathbf{2 3}$ and 24, this fact was taken into account during the refinement.

The various advanced features (e.g. constraints and restraints) of SHELXL program were used to treat the disordered groups, lattice solvents such as toluene or THF, and the hydrogen atoms. Positions of the hydrogen atoms attached to the $\mathrm{N}$ atoms of the 
bridges in structure $\mathbf{1 8}$ were freely refined. Crystal data for all compounds along with structure factors and refinement are tabulated in Section 6.

\subsection{Starting Materials}

The scandium, yttrium, lanthanum, and cerium halogenides were synthesized following the literature methods: $\mathrm{ScCl}_{3} \cdot 3 \mathrm{THF}$ from the hydrate, ${ }^{[113]} \mathrm{LnX}_{3}(\mathrm{Ln}=\mathrm{Sc}, \mathrm{Y}, \mathrm{X}$ $=\mathrm{Br}, \mathrm{I}$ ) from the metals and the corresponding halides, ${ }^{[114]} \mathrm{LaCl}_{3}$ and $\mathrm{CeCl}_{3}$ from their oxides in concentrated $\mathrm{HCl}$ solution. ${ }^{[115]} \mathrm{YCl}_{3}, \mathrm{LuCl}_{3}$, and $\mathrm{Ag}\left(\mathrm{SO}_{3} \mathrm{CF}_{3}\right)_{2}$ were used as received (Strem, Aldrich).

LLi ( $\mathrm{L}=\mathrm{Et}_{2} \mathrm{NCH}_{2} \mathrm{CH}_{2} \mathrm{NC}(\mathrm{Me}) \mathrm{CHC}(\mathrm{Me}) \mathrm{NCH}_{2} \mathrm{CH}_{2} \mathrm{NEt}_{2}$ ) was synthesized in situ following a reported procedure. ${ }^{[32]} \mathrm{H}_{2} \mathrm{O} \cdot \mathrm{B}\left(\mathrm{C}_{6} \mathrm{~F}_{5}\right)_{3}{ }^{[116]}$ was synthesized from $\mathrm{B}\left(\mathrm{C}_{6} \mathrm{~F}_{5}\right)_{3}$, ${ }^{[117]}$ and $\mathrm{Me}_{3} \mathrm{SnF}$ from $\mathrm{Me}_{3} \mathrm{SnCl} .^{[118]}$

\subsubsection{Synthesis of $\operatorname{LScCl}_{2}(5), \operatorname{LScBr}_{2}(6), \mathrm{LYCl}_{2}(7), \mathrm{LYBr}_{2}(8)$, and $\mathrm{LLuCl}_{2}(9)$}

The dihalogenide 5-9 have been prepared using identical procedures. To 0.9 mmol of LLi obtained in situ ${ }^{[32]}$ toluene $(30 \mathrm{~mL})$ was added. The solution was added dropwise to suspensions of $0.9 \mathrm{mmol} \mathrm{LnX}_{3}$ in toluene $(25 \mathrm{~mL})$ in a $100 \mathrm{~mL}$ Schlenk flask. Then, the reaction mixtures were refluxed overnight, in the case of scandium salts for two days. The suspensions were filtered hot, the solvent removed, and the crude product washed with pentane $(50 \mathrm{~mL})$ then dried in vacuo. For $\mathrm{LYCl}_{2}$ and $\mathrm{LLuCl}_{2}$ removal of the solvent and extraction of the product with dichloromethane followed the refluxing step.

Compound 5 could also be prepared by an alternative procedure from $\mathrm{ScCl}_{3} \cdot 3 \mathrm{THF}$.

A solution of LLi $(2.70 \mathrm{~g}, 0.9 \mathrm{mmol})$ in THF $(25 \mathrm{~mL})$ was added to a suspension of $\mathrm{ScCl}_{3} \cdot 3$ THF $(3.33 \mathrm{~g}, 0.9 \mathrm{mmol})$ in THF $(50 \mathrm{~mL})$. The resulting yellow solution was stirred overnight at room temperature, then the solvent removed in vacuo, and the solid material extracted with toluene $(50 \mathrm{~mL})$. Subsequent removal of the toluene led to $3.30 \mathrm{~g}$ $(88.5 \%)$ of 5 .

Single crystals for X-ray measurements were obtained cooling the mother liquor to $26{ }^{\circ} \mathrm{C}$. 
5: Yield for the first method: $3.32 \mathrm{~g}(90.5 \%)$; Yield for the second method: $3.25 \mathrm{~g}(88.5$ \%). Anal. Calcd for $\mathrm{C}_{17} \mathrm{H}_{35} \mathrm{Cl}_{2} \mathrm{~N}_{4} \mathrm{Sc}$ (411.35, \%): C, 49.63; H, 8.57; N, 13.62. Found: C, 49.5; H, 8.4; N, 13.4. ${ }^{1} \mathrm{H}$ NMR (200.13 MHz, $\left.\mathrm{C}_{6} \mathrm{D}_{6}, 300 \mathrm{~K}\right): \delta=4.82$ (s, $\left.1 \mathrm{H}, \mathrm{CH}\right), 3.08$ $\left(\mathrm{m}, 16 \mathrm{H}, \mathrm{NCH}_{2} \mathrm{CH}_{2} \mathrm{~N}\left(\mathrm{CH}_{2}\right)_{2}\right), 1.6\left(\mathrm{~s}, 6 \mathrm{H}, \mathrm{CHCCH}_{3}\right), 0.85\left(\mathrm{t}, 12 \mathrm{H}, \mathrm{CH}_{2} \mathrm{CH}_{3}\right) ;{ }^{13} \mathrm{C} \mathrm{NMR}$ $\left(125.75 \mathrm{MHz}, \mathrm{C}_{6} \mathrm{D}_{6}, 300 \mathrm{~K}\right): \delta=165.46(\mathrm{CCHC}), 99.56(\mathrm{CH}), 54.7\left(\mathrm{CNCH}_{2}\right), 47.67$ $\left(\mathrm{NCH}_{2} \mathrm{CH}_{2}\right), 30.16\left(\mathrm{CH}_{2} \mathrm{NCH}_{2}\right), 22.34\left(\mathrm{CHCCH}_{3}\right), 8.64\left(\mathrm{NCH}_{2} \mathrm{CH}_{3}\right) ;{ }^{45} \mathrm{Sc} \mathrm{NMR}(121.49$ $\left.\mathrm{MHz}, \mathrm{C}_{6} \mathrm{D}_{6}, 300 \mathrm{~K}\right): \delta=286.21$; M.p. $159-161{ }^{\circ} \mathrm{C}$; EI-MS: $m / z$ (rel. int. \%)): $410\left(\mathrm{M}^{+}\right.$, 10), $324\left(\mathrm{M}^{+}-\mathrm{C}_{5} \mathrm{H}_{12} \mathrm{~N}, 100\right)$.

6: Yield: 3.86 g (86.6 \%). Anal. Calcd. for $\mathrm{C}_{17} \mathrm{H}_{35} \mathrm{Br}_{2} \mathrm{~N}_{4} \mathrm{Sc}$ (500.27, \%): C, 40.58; H, 7.30; N, 10.90; Found: C, 40.8; H, 7.0; N, 11.2; ${ }^{1} \mathrm{H}$ NMR (200.13 MHz, $\left.\mathrm{C}_{6} \mathrm{D}_{6}, 300 \mathrm{~K}\right): \delta$ $=4.82(\mathrm{~s}, 1 \mathrm{H} ; \mathrm{CH}), 3.08\left(\mathrm{~m}, 16 \mathrm{H}, \mathrm{NCH}_{2} \mathrm{CH}_{2} \mathrm{~N}\left(\mathrm{CH}_{2}\right)_{2}\right), 1.55\left(\mathrm{~s}, 6 \mathrm{H}, \mathrm{CHCCH}_{3}\right), 0.82(\mathrm{t}$, $\left.12 \mathrm{H}, \mathrm{CH}_{2} \mathrm{CH}_{3}\right) ;{ }^{13} \mathrm{C}$ NMR (125.75 MHz, $\left.\mathrm{C}_{6} \mathrm{D}_{6}, 300 \mathrm{~K}\right): \delta=165.38(\mathrm{CCHC}), 100.57$ $(\mathrm{CH}), 54.7\left(\mathrm{CNCH}_{2}\right), 47.81\left(\mathrm{NCH}_{2} \mathrm{CH}_{2}\right), 30.16\left(\mathrm{CH}_{2} \mathrm{NCH}_{2}\right), 22.34\left(\mathrm{CHCCH}_{3}\right), 8.97$ $\left(\mathrm{NCH}_{2} \mathrm{CH}_{3}\right) ;{ }^{45} \mathrm{Sc} \mathrm{NMR}\left(121.49 \mathrm{MHz}, \mathrm{C}_{6} \mathrm{D}_{6}, 300 \mathrm{~K}\right): \delta=335.87$; M.p. $131-136{ }^{\circ} \mathrm{C}$; EIMS: $m / z$ (rel. int. \%) $500\left[\mathrm{M}^{+}, 10\right], 414\left[\mathrm{M}^{+}-\mathrm{C}_{5} \mathrm{H}_{12} \mathrm{~N}, 100\right]$.

7: Yield: 3.29 g (81.3 \%). Anal. Calcd. for $\mathrm{C}_{17} \mathrm{H}_{35} \mathrm{Cl}_{2} \mathrm{~N}_{4} \mathrm{Y}$ (454.13, \%): C, 44.85; H, 7.75; $\mathrm{N}, 12.31$; Found: C, 44.5; H, 7.9; N, 12.7; ${ }^{1} \mathrm{H}$ NMR (200.13 MHz, $\left.\mathrm{C}_{6} \mathrm{D}_{6}, 300 \mathrm{~K}\right): \delta=4.79$ $(\mathrm{s}, 1 \mathrm{H}, \mathrm{CH}), 3.10\left(\mathrm{~m}, 16 \mathrm{H}, \mathrm{NCH}_{2} \mathrm{CH}_{2} \mathrm{~N}\left(\mathrm{CH}_{2}\right)_{2}\right), 1.55\left(\mathrm{~s}, 6 \mathrm{H}, \mathrm{CHCCH}_{3}\right), 0.82(\mathrm{t}, 12 \mathrm{H}$, $\left.\mathrm{CH}_{2} \mathrm{CH}_{3}\right) ;{ }^{13} \mathrm{C}$ NMR $\left(125.75 \mathrm{MHz}, \mathrm{C}_{6} \mathrm{D}_{6}, 300 \mathrm{~K}\right): \delta=166.25(\mathrm{CCHC}), 99.89(\mathrm{CH}), 55.07$ $\left(\mathrm{CNCH}_{2}\right), 49.43\left(\mathrm{NCH}_{2} \mathrm{CH}_{2}\right), 30.10\left(\mathrm{CH}_{2} \mathrm{NCH}_{2}\right), 23.08\left(\mathrm{CHCCH}_{3}\right), 8.25\left(\mathrm{NCH}_{2} \mathrm{CH}_{3}\right)$; M.p. $170-185^{\circ} \mathrm{C}$; EI-MS: $m / z$ (rel. int. \%) $454\left[\mathrm{M}^{+}, 10\right], 368\left[\mathrm{M}^{+}-\mathrm{C}_{5} \mathrm{H}_{12} \mathrm{~N}, 45\right], 86$ $\left[\mathrm{C}_{5} \mathrm{H}_{12} \mathrm{~N}^{+}, 100\right]$.

8: Yield: 4.15 g (85.5 \%).Anal. Calcd. for $\mathrm{C}_{17} \mathrm{H}_{35} \mathrm{Br}_{2} \mathrm{~N}_{4} \mathrm{Y}$ (544.03, \%): C, 37.52; H, 6.48; $\mathrm{N}, 10.20$. Found: C, 37.3; H, 6.6; N, 10.0. ${ }^{1} \mathrm{H}$ NMR $\left(200 \mathrm{MHz}, \mathrm{C}_{6} \mathrm{D}_{6}, 300 \mathrm{~K}\right): \delta=4.80$ (s, $1 \mathrm{H}, \mathrm{CH}), 3.10\left(\mathrm{~m}, 16 \mathrm{H}, \mathrm{NCH}_{2} \mathrm{CH}_{2} \mathrm{~N}\left(\mathrm{CH}_{2}\right)_{2}\right), 1.59\left(\mathrm{~s}, 6 \mathrm{H}, \mathrm{CHCCH}_{3}\right), 0.82$ (t, $12 \mathrm{H}$, $\left.\mathrm{CH}_{2} \mathrm{CH}_{3}\right) ;{ }^{13} \mathrm{C}$ NMR $\left(125.75 \mathrm{MHz}, \mathrm{C}_{6} \mathrm{D}_{6}, 300 \mathrm{~K}\right): \delta=166.25(\mathrm{CCHC}), 99.91(\mathrm{CH}), 55.07$ 
$\left(\mathrm{CNCH}_{2}\right), 49.43\left(\mathrm{NCH}_{2} \mathrm{CH}_{2}\right), 30.10\left(\mathrm{CH}_{2} \mathrm{NCH}_{2}\right), 23.03\left(\mathrm{CHCCH}_{3}\right), 8.23\left(\mathrm{NCH}_{2} \mathrm{CH}_{3}\right)$; M.p. 150 - $155^{\circ} \mathrm{C}$; EI-MS: $m / z$ (rel int \%) $544\left[\mathrm{M}^{+}, 8\right], 458\left[\mathrm{M}^{+}-\mathrm{C}_{5} \mathrm{H}_{12} \mathrm{~N}, 100\right]$.

9: Yield: 3.63 g (75.3 \%). Anal. Calcd. for $\mathrm{C}_{17} \mathrm{H}_{35} \mathrm{Cl}_{2} \mathrm{~N}_{4} \mathrm{Lu}(540.16, \%)$ : C, 37.72; $\mathrm{H}$, 6.52; N, 10.35. Found: C, 37.4; H, 6.7; N, 10.1. ${ }^{1} \mathrm{H}$ NMR (200 MHz, $\left.\mathrm{C}_{6} \mathrm{D}_{6}, 300 \mathrm{~K}\right): \delta=$ $4.44(\mathrm{~s}, 1 \mathrm{H}, \mathrm{CH}), 3.00\left(\mathrm{~m}, 16 \mathrm{H}, \mathrm{NCH}_{2} \mathrm{CH}_{2} \mathrm{~N}\left(\mathrm{CH}_{2}\right)_{2}\right), 1.62$ (s, $\left.6 \mathrm{H}, \mathrm{CHCCH}_{3}\right), 0.84$ (t, $\left.12 \mathrm{H}, \mathrm{CH}_{2} \mathrm{CH}_{3}\right) ;{ }^{13} \mathrm{C}$ NMR (125.75 MHz, $\left.\mathrm{C}_{6} \mathrm{D}_{6}, 300 \mathrm{~K}\right): \delta=167.40(\mathrm{CCHC}), 99.55(\mathrm{CH})$, $55.08\left(\mathrm{CNCH}_{2}\right), 49.94\left(\mathrm{NCH}_{2} \mathrm{CH}_{2}\right), 30.00\left(\mathrm{CH}_{2} \mathrm{NCH}_{2}\right), 23.06\left(\mathrm{CHCCH}_{3}\right), 8.11$ $\left(\mathrm{NCH}_{2} \mathrm{CH}_{3}\right.$ ); M.p. $200-223{ }^{\circ} \mathrm{C}$; EI-MS: $m / z$ (rel. int. \%) $541\left[\mathrm{M}^{+}, 10\right], 454\left[\mathrm{M}^{+}-\mathrm{C}_{5} \mathrm{H}_{12} \mathrm{~N}\right.$, $60], 86\left[\mathrm{C}_{5} \mathrm{H}_{12} \mathrm{~N}^{+}, 100\right]$.

\subsubsection{Synthesis of $\operatorname{LScI}_{2}(10)$ and $\operatorname{LYI}_{2}(11)$,}

The diiodides have been prepared by similar procedures. $1.8 \mathrm{mmol}$ of LK were obtained in situ by refluxing $1.8 \mathrm{mmol} \mathrm{LH}$ with $2.5 \mathrm{mmol} \mathrm{KH}$ in toluene $(30 \mathrm{~mL})$ and filtering off excess $\mathrm{KH}$. The resulting solutions were added dropwise to a suspension of $1.8 \mathrm{mmol} \mathrm{LnI}_{3}$ in toluene $(25 \mathrm{~mL})$ in a $100 \mathrm{~mL}$ Schlenk flask. Then, the reaction mixture was refluxed for 1 day. The suspensions were filtered hot, the solvent removed and the crude product was washed with pentane $(50 \mathrm{~mL})$ then dried in vacuum.

10: Yield: 8.4 g (78.5 \%). Anal. Calcd. for $\mathrm{C}_{17} \mathrm{H}_{35} \mathrm{I}_{2} \mathrm{~N}_{4} \mathrm{Sc}$ (594.05, \%): C, 34.36; H, 5.94; N, 9.43; Found: C, 34.55; H, 5.80; N, 9.38; ${ }^{1} \mathrm{H}$ NMR (200 MHz, $\left.\mathrm{C}_{6} \mathrm{D}_{6}, 300 \mathrm{~K}\right): \delta=4.74$ (s, $1 \mathrm{H}, \mathrm{CH}), 3.17,2.98\left(\mathrm{~m}, 16 \mathrm{H}, \mathrm{NCH}_{2} \mathrm{CH}_{2} \mathrm{~N}\left(\mathrm{CH}_{2}\right)_{2}\right), 1.47\left(\mathrm{~s}, 6 \mathrm{H}, \mathrm{CHCCH}_{3}\right), 0.82$ (t, $\left.12 \mathrm{H}, \mathrm{CH}_{2} \mathrm{CH}_{3}\right) ;{ }^{13} \mathrm{C}$ NMR (125.75 MHz, $\left.\mathrm{C}_{6} \mathrm{D}_{6}, 300 \mathrm{~K}\right): \delta=166.30(\mathrm{CCHC}), 100.08$ $(\mathrm{CH}), 54.90\left(\mathrm{CNCH}_{2}\right), 47.67\left(\mathrm{NCH}_{2} \mathrm{CH}_{2}\right), 30.10\left(\mathrm{CH}_{2} \mathrm{NCH}_{2}\right), 23.05\left(\mathrm{CHCCH}_{3}\right), 8.86$ $\left(\mathrm{NCH}_{2} \mathrm{CH}_{3}\right) ;{ }^{45} \mathrm{Sc} \mathrm{NMR}\left(121.49 \mathrm{MHz}, \mathrm{C}_{6} \mathrm{D}_{6}, 300 \mathrm{~K}\right): \delta=392.13$; M.p. $115-122{ }^{\circ} \mathrm{C}$ with decomposition; EI-MS: $m / z$ (rel. int. \%) 127 [I, 15], $86\left[\mathrm{C}_{5} \mathrm{H}_{12} \mathrm{~N}^{+}, 100\right]$

11: Yield: 8.08 g (70.4 \% ). Anal. Calcd. for $\mathrm{C}_{17} \mathrm{H}_{35} \mathrm{I}_{2} \mathrm{~N}_{4} \mathrm{Y}$ (638.00, \%): C, 31.99; H, 5.53; N, 8.78. Found: C, 32.20; H, 5.40; N, 8.56. ${ }^{1} \mathrm{H}$ NMR $\left(200.13 \mathrm{MHz}, \mathrm{C}_{6} \mathrm{D}_{6}, 300 \mathrm{~K}\right): \delta=$ $4.80(\mathrm{~s}, 1 \mathrm{H}, \mathrm{CH}), 3.10\left(\mathrm{~m}, 16 \mathrm{H}, \mathrm{NCH}_{2} \mathrm{CH}_{2} \mathrm{~N}\left(\mathrm{CH}_{2}\right)_{2}\right), 1.55$ (s, $\left.6 \mathrm{H}, \mathrm{CHCCH}_{3}\right), 0.78$ (t, 12 $\left.\mathrm{H}, \mathrm{CH}_{2} \mathrm{CH}_{3}\right) ;{ }^{13} \mathrm{C}$ NMR (125.75 MHz, $\left.\mathrm{C}_{6} \mathrm{D}_{6}, 300 \mathrm{~K}\right): \delta=166.37(\mathrm{CCHC}), 101.04(\mathrm{CH})$, 
$55.10\left(\mathrm{CNCH}_{2}\right), 46.93\left(\mathrm{NCH}_{2} \mathrm{CH}_{2}\right), \quad 30.10\left(\mathrm{CH}_{2} \mathrm{NCH}_{2}\right), 22.94 \quad\left(\mathrm{CHCCH}_{3}\right), \quad 8.48$ $\left(\mathrm{NCH}_{2} \mathrm{CH}_{3}\right.$ ); M.p. 150 - $155^{\circ} \mathrm{C}$; EI-MS: $m / z$ (rel. int. \%) 511 [M $\mathrm{M}^{+}$-I, 5 ], 127 [I, 10], 86 $\left[\mathrm{C}_{5} \mathrm{H}_{12} \mathrm{~N}^{+}, 100\right]$

\subsubsection{Synthesis of $\mathrm{LLaCl}_{2} \cdot \mathrm{LLi}(12)$ and $\mathrm{LCeCl}_{2} \cdot \operatorname{LLi}(13)$}

To a mixture of $1 \mathrm{mmol}$ of LLi obtained in situ ${ }^{[32]}$ and $1 \mathrm{mmol}$ of $\mathrm{LnCl}_{3}$ toluene $(50 \mathrm{~mL})$ was added. The suspension was boiled to reflux for 1 day, filtered while hot and the solvent was removed under reduced pressure. The resulting orange oil was recrystallized from hexane with a few drops of toluene and deposited at $-20{ }^{\circ} \mathrm{C}$. Crystals of the respective adduct precipitated overnight and they were collected by filtration. The compound decomposed slowly even in the glove box becoming oily.

12: Yield: 0.24 g (30.5 \%). Anal. Calcd. for $\mathrm{C}_{34} \mathrm{H}_{70} \mathrm{~N}_{8} \mathrm{Cl}_{2} \mathrm{LaLi}(806.43, \%)$ : $\mathrm{C}, 50.55 ; \mathrm{H}$, 8.73; N, 13.8. Found: C, 50.12; H, 8.63; N, 13.42. ${ }^{1} \mathrm{H}$ NMR (200.13 MHz, $\left.\mathrm{C}_{6} \mathrm{D}_{6}, 300 \mathrm{~K}\right)$ : $\delta=4.78(\mathrm{~s}, 1 \mathrm{H} ; \mathrm{CH} \mathrm{LLi}), 4.50\left(\mathrm{~s}, 1 \mathrm{H} ; \mathrm{CH} \mathrm{LLaCl}_{2}\right), 3.39\left(\mathrm{t}, 4 \mathrm{H}, \mathrm{NCH}_{2} \mathrm{CH}_{2} \mathrm{~N}_{\left(\mathrm{CH}_{2}\right)_{2}}\right.$ LLi), $3.05\left(\mathrm{~m}, 16 \mathrm{H}, \mathrm{CH}_{2} \mathrm{~N}\left(\mathrm{CH}_{2} \mathrm{CH}_{3}\right)_{2} \mathrm{LLaCl}_{2}\right), 2.47\left(\mathrm{~m}, 12 \mathrm{H}, \mathrm{CH}_{2} \mathrm{~N}\left(\mathrm{CH}_{2} \mathrm{CH}_{3}\right)_{2} \mathrm{LLi}\right)$, 2.05 (s, $\left.6 \mathrm{H}, \mathrm{CHCCH}_{3} \mathrm{LLi}\right), 1.48$ (s, $6 \mathrm{H}, \mathrm{CHCCH}_{3}, \mathrm{LLaCl}_{2}$ ), 0.78 (t, $\left.12 \mathrm{H}, \mathrm{CH}_{2} \mathrm{CH}_{3} \mathrm{LLi}\right)$, $0.70\left(\mathrm{t}, 12 \mathrm{H}, \mathrm{CH}_{2} \mathrm{CH}_{3} \mathrm{LLaCl}_{2}\right) ;{ }^{7} \mathrm{Li} \mathrm{NMR}\left(300 \mathrm{MHz}, \mathrm{C}_{6} \mathrm{D}_{6}, 300 \mathrm{~K}\right): \delta=0.61$; M.p. 92 $98{ }^{\circ} \mathrm{C}$; EI-MS: $m / z$ (rel. int. \%) $504\left[\mathrm{LLaCl}_{2}^{+}, 10\right], 302\left[\mathrm{LLi}^{+}, 8\right], 86\left[\mathrm{C}_{5} \mathrm{H}_{12} \mathrm{~N}^{+}, 100\right]$.

13: Yield: 0.28 g (35.4 \%). Anal. Calcd. for $\mathrm{C}_{34} \mathrm{H}_{70} \mathrm{~N}_{8} \mathrm{Cl}_{2} \mathrm{CeLi}(807.73, \%)$ : C, 50.48; $\mathrm{H}$, 8.72; N, 13.85. Found: C, 50.60; H, 8.70; N, 14.05. M.p. 95-110 ${ }^{\circ} \mathrm{C}$; EI-MS: $m / z$ (rel. int. \%) 765, $\left[\mathrm{M}^{+}-\mathrm{LiCl}, 5\right], 505\left[\mathrm{LCeCl}_{2}^{+}, 10\right], 471\left[\mathrm{LCeCl}^{+}, 50\right], 302\left[\mathrm{LLi}^{+}, 8\right], 86\left[\mathrm{C}_{5} \mathrm{H}_{12} \mathrm{~N}^{+}\right.$, $100]$.

\subsubsection{Synthesis of $\left[(\mathrm{L}-\mathrm{H}) \mathrm{ScN}\left(\mathrm{SiMe}_{3}\right)_{2}\right]_{2}(14)$.}

Toluene $(25 \mathrm{~mL})$ was added to a mixture of 5 (1.0 g, $2.43 \mathrm{mmol})$ and $\mathrm{NaN}\left(\mathrm{SiMe}_{3}\right)_{2}(0.9 \mathrm{~g}, 4.87 \mathrm{mmol})$. The resulting red solution was stirred overnight and then filtered, concentrated, and kept at $-26{ }^{\circ} \mathrm{C}$. After 3 days, crystals of $\mathbf{1 3}$ could be filtered off and dried under a nitrogen stream. 
Yield: $0.20 \mathrm{~g}(19.1 \%)$ of $13 \cdot 0.74 \mathrm{C}_{7} \mathrm{H}_{8}$ (the composition is due to the drying procedure).

Anal. Calcd for $\mathrm{C}_{46} \mathrm{H}_{104} \mathrm{~N}_{10} \mathrm{Sc}_{2} \mathrm{Si}_{4} \cdot 0.74 \mathrm{C}_{7} \mathrm{H}_{8}$ (1067.83, \%): C, 57.57; H, 10.38; N, 13.12 . Found: C, 57.3; H, 9.9; N, 12.7. ${ }^{1} \mathrm{H}$ NMR (200.13 MHz, $\left.\mathrm{C}_{6} \mathrm{D}_{6}, 300 \mathrm{~K}\right): \delta=5.16(\mathrm{~s}, 2 \mathrm{H}$, $\mathrm{CH}), 4.15(\mathrm{~m}), 3.3(\mathrm{~m}), 3.09(\mathrm{~m}), 2.92(\mathrm{br}), 2.81(\mathrm{~m}), 2.65(\mathrm{~m}), 2.55(\mathrm{t}), 2.4(\mathrm{~m}), 2.24$ and $1.93\left(\mathrm{~d}, 1 \mathrm{H}, \mathrm{CH}_{2}\right.$ bridge, overlapping with toluene signal), $1.82\left(\mathrm{~s}, 12 \mathrm{H}, \mathrm{CHCCH}_{3}\right), 0.96$ (t, $\left.12 \mathrm{H}, \mathrm{NCH}_{2} \mathrm{CH}_{3}\right), 0.85$ (br, $\left.12 \mathrm{H}, \mathrm{NCH}_{2} \mathrm{CH}_{3}\right), 0.59,0.40\left(2 \mathrm{~s}, 18 \mathrm{H}, \mathrm{N}\left(\mathrm{SiMe}_{3}\right)_{2}\right) ;{ }^{13} \mathrm{C}$ NMR (125.75 MHz, $\left.\mathrm{C}_{6} \mathrm{D}_{6}, 300 \mathrm{~K}\right): \delta=156.19(\mathrm{CCH}), 137.83\left(\mathrm{CHCCH}_{2}\right), 101.34(C)$, 55.12, 50.16, 47.00, 46.59, $22.37(\mathrm{CCH} 3), 21.36\left(\mathrm{CH}_{2}\right.$ bridge overlapping with toluene signal), $12.26\left(\mathrm{NCH}_{2} \mathrm{CH}_{3}\right), 6.69,6.26\left(\mathrm{~N}\left(\mathrm{SiMe}_{3}\right)_{2}\right) ;{ }^{45} \mathrm{Sc} \mathrm{NMR}\left(121.49 \mathrm{MHz}, \mathrm{C}_{6} \mathrm{D}_{6}, 300\right.$ $\mathrm{K}): \delta=423.64 ;{ }^{29} \mathrm{Si} \mathrm{NMR}\left(100 \mathrm{MHz}, \mathrm{C}_{6} \mathrm{D}_{6}, 300 \mathrm{~K}\right): \delta=-7.93,-10.83$; M.p. $193-195$ ${ }^{\circ} \mathrm{C}$. EI-MS m/z (rel. int. \%): $499\left[\left(\mathrm{C}_{17} \mathrm{H}_{34} \mathrm{~N}_{4} \mathrm{ScN}\left(\mathrm{SiMe}_{3}\right)_{2}{ }^{+}, 7\right], 146\left[\mathrm{NSi}_{2} \mathrm{Me}_{5}{ }^{+}, 100\right]\right.$.

\subsubsection{Synthesis of $\mathrm{LSc}\left(\mathrm{SO}_{3} \mathrm{CF}_{3}\right)_{2}(15)$}

A mixture of $0.50 \mathrm{~g}(0.98 \mathrm{mmol}) 2$ and $0.112 \mathrm{~g}(1.96 \mathrm{mmol}) \mathrm{AgSO}_{3} \mathrm{CF}_{3}$ in toluene $(35 \mathrm{~mL})$ in a $50 \mathrm{~mL}$ Schlenk flask was stirred for 2 days. The suspension was filtered. The resulting clear solution was concentrated under reduced pressure to obtain yellow crystals of 14, which were collected by filtration and washed with pentane $(10 \mathrm{~mL})$.

Yield $0.31 \mathrm{~g}\left(68 \%\right.$ ) Anal. Calcd. for $\mathrm{C}_{17} \mathrm{H}_{35} \mathrm{~F}_{6} \mathrm{~N}_{4} \mathrm{O}_{6} \mathrm{~S}_{2} \mathrm{Sc}(638.59$, \%): C, 35.74; H, 5.52; $\mathrm{N}, 8.77$; Found: C, 35.2; $\mathrm{H}, 5.5 ; \mathrm{N}, 8.6 ;{ }^{1} \mathrm{H} \mathrm{NMR}\left(200.13 \mathrm{MHz}, \mathrm{C}_{6} \mathrm{D}_{6}, 300 \mathrm{~K}\right): \delta=4.72$ (s, $1 \mathrm{H} ; \mathrm{CH}$ ), 3.03 (t, $4 \mathrm{H}, \mathrm{NCH}_{2} \mathrm{CH}_{2} \mathrm{NEt}_{2}, J=6.28 \mathrm{~Hz}$ ), 2.82 (q, $4 \mathrm{H}, \mathrm{NCH}_{2} \mathrm{CH}_{3}, J=6.47$ $\mathrm{Hz}), 2.64$ (t, $\left.4 \mathrm{H}, \mathrm{NCH}_{2} \mathrm{CH}_{2} \mathrm{NEt}_{2}, J=6.24 \mathrm{~Hz}\right) 2.47\left(\mathrm{~m}, 4 \mathrm{H}, \mathrm{NCH}_{2} \mathrm{CH}_{3}, J=6.48 \mathrm{~Hz}\right)$ 1.59 (s, $\left.6 \mathrm{H}, \mathrm{CHCCH}_{3}\right), 0.66$ (t, $\left.12 \mathrm{H}, \mathrm{CH}_{2} \mathrm{CH}_{3}, J=7.16 \mathrm{~Hz}\right) ;{ }^{13} \mathrm{C}$ NMR $(125.75 \mathrm{MHz}$, $\left.\mathrm{C}_{6} \mathrm{D}_{6}, 300 \mathrm{~K}\right): \delta=165.38(\mathrm{CCHC}), 100.57(\mathrm{CH}), 54.7\left(\mathrm{CNCH}_{2}\right), 47.81\left(\mathrm{NCH}_{2} \mathrm{CH}_{2}\right)$, $30.16\left(\mathrm{CH}_{2} \mathrm{NCH}_{2}\right), 22.34\left(\mathrm{CHCCH}_{3}\right), 8.97\left(\mathrm{NCH}_{2} \mathrm{CH}_{3}\right) ;{ }^{19} \mathrm{~F} \mathrm{NMR}\left(188 \mathrm{MHz}, \mathrm{C}_{6} \mathrm{D}_{6}, 300\right.$ $\mathrm{K}): \delta=85.01 ;{ }^{45} \mathrm{Sc}$ NMR (121.49 MHz, $\left.\mathrm{C}_{6} \mathrm{D}_{6}, 300 \mathrm{~K}\right): \delta=185.06$; M.p. $95{ }^{\circ} \mathrm{C}$; EI-MS: $m / z$ (rel. int. \%) $638\left[\mathrm{M}^{+}, 74\right], 552\left[\mathrm{M}^{+}-\mathrm{C}_{5} \mathrm{H}_{12} \mathrm{~N}, 36\right], 489\left[\mathrm{M}^{+}-\mathrm{CF}_{3} \mathrm{SO}_{3}, 100\right]$.

\subsubsection{Synthesis of $\left(\mathrm{Me}_{3} \mathrm{ClSn}-\mu-\mathrm{F}\right)_{2} \mathrm{LSc}(16)$ and $\left(\mathrm{Me}_{3} \mathrm{BrSn}-\mu-\mathrm{F}\right)_{2} \mathrm{LSc}(17 \mathrm{a}, 17 \mathrm{~b})$}

Compounds 16 and $\mathbf{1 7}$ were obtained analogously. Only the synthesis of $\mathbf{1 7}$ is presented. 
A mixture of $0.50 \mathrm{~g}(0.98 \mathrm{mmol}) 6$ and $0.35 \mathrm{~g}(1.96 \mathrm{mmol})$ of $\mathrm{Me}_{3} \mathrm{SnF}$ in a Schlenk flask in toluene $(50 \mathrm{~mL})$ was stirred for 1 day until all the $\mathrm{Me}_{3} \mathrm{SnF}$ dissolved. The resulting solution was concentrated under reduced pressure and kept at $-26{ }^{\circ} \mathrm{C}$. After $3 \mathrm{~d}$ crystals of $\mathbf{1 7}$ were obtained. A cold filtration afforded $0.43 \mathrm{~g}$ of $\mathbf{1 7}$ (yield $51.0 \%$ ). Attempts to dissolve again the product in $\mathrm{CDCl}_{3}$ or $\mathrm{C}_{6} \mathrm{D}_{6}$ for characterizing 17 by NMR failed. 17 decomposed rapidly once that it was taken out of the solution. EI-MS: $m / z$ (rel. int. \%) $359\left[\mathrm{LScF}^{+}, 15\right], 165\left[\mathrm{Me}_{3} \mathrm{Sn}^{+}, 5\right], 86\left[\mathrm{C}_{5} \mathrm{H}_{12} \mathrm{~N}^{+}, 100\right]$.

16: Yield 0.45 g (66.1 \%); EI-MS: $m / z$ (rel. int. \%) 359 [ $\left.\mathrm{LScF}^{+}, 20\right], 165\left[\mathrm{Me}_{3} \mathrm{Sn}^{+}, 5\right], 86$ $\left[\mathrm{C}_{5} \mathrm{H}_{12} \mathrm{~N}^{+}, 100\right]$.

\subsubsection{Synthesis of $\left[\mathrm{LY}\left(\mathrm{N}\left(\mathrm{SiMe}_{3}\right)\left(\mathrm{SiMe}_{2}\right) \mathrm{NH}\right]_{2}(18)\right.$}

Toluene $(15 \mathrm{~mL})$ was added to a mixture of $7(0.50 \mathrm{~g}, 1.1 \mathrm{mmol})$ and $\mathrm{NaN}\left(\mathrm{SiMe}_{3}\right)_{2}(0.40 \mathrm{~g}, 2.2 \mathrm{mmol})$. The resulting orange suspension was stirred overnight and then filtered, concentrated to less than $5 \mathrm{~mL}$, and kept at $-26{ }^{\circ} \mathrm{C}$. After 5 days, crystals of 18 precipitated that could be analyzed by X-ray analysis. Yield: $0.02 \mathrm{~g}(3.1 \%)$ of 18; M.p. 204 - $209{ }^{\circ} \mathrm{C}$; EI-MS: $m / z$ (rel. int. \%) 544 [LYNSiMe $3(\mathrm{NH}) \mathrm{SiMe}_{2}{ }^{+}, 15$ ], 145 $\left[\mathrm{NSi}_{2} \mathrm{Me}_{5}^{+}, 100\right]$.

\subsubsection{Synthesis of (LMgBr) $)_{2} \operatorname{ScBr}(19)$}

To a solution of $\mathrm{LScBr}_{2}(\mathbf{6})(0.50 \mathrm{~g}, 0.99 \mathrm{mmol})$ in $20 \mathrm{~mL}$ THF, $2 \mathrm{~mL}$ of $\mathrm{C}_{3} \mathrm{H}_{5} \mathrm{MgBr}(1 \mathrm{M}$ in ether, $2.0 \mathrm{mmol})$ were added at $0{ }^{\circ} \mathrm{C}$. The mixture was left to react for additional $5 \mathrm{~h}$ while it reached room temperature. In the meantime the color of the suspension changed from yellow to dark brown. Then all the volatiles were removed in vacuum and $25 \mathrm{~mL}$ of toluene were added. The precipitate was filtered off to give a dark blue solution that was concentrated to approximately $10 \mathrm{~mL}$. Overnight blue green crystals of 19 were formed. The crystals were separated and washed with small amounts of toluene and dried in vacuum $(0.125 \mathrm{~g}, 25.8 \%)$.

Anal: Calcd. for $\left(\mathrm{C}_{17} \mathrm{H}_{35} \mathrm{~N}_{4} \mathrm{MgBr}\right)_{2} \mathrm{ScBr} \cdot 0.5 \mathrm{C}_{7} \mathrm{H}_{8}$ (970.32, \%): C, 46.41; H, 7.68; N, 11.54. Found: C, 46.44; H, 7.57; N, 10.60 (composition due to the drying procedure). Due to the easy decomposition of $\mathbf{1 9}$ we were not able to remove completely the solvent 
molecules and repeated attempts consistently gave low nitrogen analyses for this compound. ${ }^{1} \mathrm{H}$ NMR $\left(500 \mathrm{MHz}, \mathrm{C}_{6} \mathrm{D}_{6}, 300 \mathrm{~K}\right.$ ): $\delta=3.63$ (br, $4 \mathrm{H} ; \mathrm{Et}_{2} \mathrm{NCH}_{2} \mathrm{CH}_{2}$ ), 3.49 (br, $8 \mathrm{H}, \mathrm{NCH}_{2} \mathrm{CH}_{3}$ ), 3.2 (t, $\left.4 \mathrm{H}, \mathrm{Et}_{2} \mathrm{NCH}_{2} \mathrm{CH}_{2}\right), 2.82$ (s, $2 \mathrm{H}, \mathrm{C}(\mathrm{Me}) \mathrm{CHC}(\mathrm{Me}), 2.6$ (br, $8 \mathrm{H}$, $\left.\mathrm{NCH}_{2} \mathrm{CH}_{3}\right) ; 2.41$ (d, $\left.4 \mathrm{H}, \mathrm{Et}_{2} \mathrm{NCH}_{2} \mathrm{CH}_{2}\right), 2.28$ (d, $\left.4 \mathrm{H}, \mathrm{Et}_{2} \mathrm{NCH}_{2} \mathrm{CH}_{2}\right), 1.82$ (s, $12 \mathrm{H}$, $\left.\mathrm{CCH}_{3}\right), 0.91$ (br, $\left.24 \mathrm{H}, \mathrm{NCH}_{2} \mathrm{CH}_{3}\right) .{ }^{13} \mathrm{C} \mathrm{NMR}\left(125.75 \mathrm{MHz}, \mathrm{C}_{6} \mathrm{D}_{6}, 300 \mathrm{~K}\right): \delta=129.27$, 92.81, 55.11, 45.78, 44.29, 20.87, 9.5. ${ }^{45} \mathrm{Sc}$ NMR (121.49 MHz, $\left.\mathrm{C}_{6} \mathrm{D}_{6}, 300 \mathrm{~K}\right): \delta=167.4$; EI-MS: $m / z$ (rel. int. \%) $400\left[\mathrm{LMgBr}^{+}, 5\right], 314\left[\mathrm{LMgBr}^{+}-\mathrm{C}_{5} \mathrm{H}_{12} \mathrm{~N}, 50\right], 86\left[\mathrm{C}_{5} \mathrm{H}_{12} \mathrm{~N}^{+}\right.$, 100]. UV-vis $\left(\mathrm{C}_{6} \mathrm{D}_{6}\right) 570 \mathrm{~nm}$.

\subsubsection{Synthesis of $\operatorname{LSc}\left(\mathrm{OB}\left(\mathrm{C}_{6} \mathrm{~F}_{5}\right)_{2}\right)_{2}(20)$}

$0.10 \mathrm{~g}(1.8 \mathrm{mmol}) \mathrm{H}_{2} \mathrm{O} \cdot \mathrm{B}\left(\mathrm{C}_{6} \mathrm{~F}_{5}\right)_{3}$ were added to a solution of $0.075 \mathrm{~g}(0.07 \mathrm{mmol})$ 19 (obtained from the reaction of $0.30 \mathrm{~g}(0.6 \mathrm{mmol}) \mathrm{LScBr}_{2}$ with $1.2 \mathrm{~mL}\left(\mathrm{C}_{3} \mathrm{H}_{5}\right) \mathrm{MgBr}$ (1 $\mathrm{M}$ in ether, $1.2 \mathrm{mmol})$ for an yield of $25 \%)$ in toluene $(10 \mathrm{~mL})$. The reaction is immediate and the color of the solution turns to brown. After stirring for an additional hour the solution was concentrated to approx. $5 \mathrm{~mL}$ until it became turbid and $5 \mathrm{~mL}$ THF were added to dissolve the precipitate. Colorless crystals of 20 suitable for X-rays analysis appeared after one week at $-26{ }^{\circ} \mathrm{C}$ (aprox. $0.05 \mathrm{~g}$ ).

Anal: Calcd for $\mathrm{C}_{41} \mathrm{H}_{35} \mathrm{~N}_{4} \mathrm{~B}_{2} \mathrm{~F}_{20} \mathrm{O}_{2} \mathrm{Sc}(1062.29$, \%): C, 46.36; H, 3.32; N, 5.27. Found: C, 46.86; H, 3.98; N, $5.06{ }^{1} \mathrm{H}$ NMR (500 MHz, $\left.\mathrm{C}_{6} \mathrm{D}_{6}, 300 \mathrm{~K}\right): \delta=3.51(\mathrm{~s}, 1 \mathrm{H}$, $\mathrm{C}(\mathrm{Me}) \mathrm{CHC}(\mathrm{Me}), 2.96$ (t, $\left.4 \mathrm{H} ; \mathrm{Et}_{2} \mathrm{NCH}_{2} \mathrm{CH}_{2}\right), 2.75\left(\mathrm{~m}, 8 \mathrm{H}, \mathrm{NCH}_{2} \mathrm{CH}_{3}\right), 2.58$ (t, $4 \mathrm{H}$, $\left.\mathrm{Et}_{2} \mathrm{NCH}_{2} \mathrm{CH}_{2}\right), 1.40\left(\mathrm{~s}, 6 \mathrm{H},, \mathrm{CCH}_{3}\right), 0.72\left(\mathrm{t}, \mathrm{NCH}_{2} \mathrm{CH}_{3}\right) .{ }^{19} \mathrm{~F} \mathrm{NMR}\left(188 \mathrm{MHz}, \mathrm{C}_{6} \mathrm{D}_{6}, 300\right.$ $\mathrm{K}):-136.7\left(\mathrm{q}, 8 \mathrm{~F}, \mathrm{BC}_{6} \mathrm{~F}_{5}\right.$ ortho $),-155.8\left(\mathrm{t}, 4 \mathrm{~F}, \mathrm{BC}_{6} \mathrm{~F}_{5}\right.$ para $),-162.7\left(\mathrm{~m}, 8 \mathrm{~F}, \mathrm{BC}_{6} \mathrm{~F}_{5}\right.$ meta $)$.

${ }^{45} \mathrm{Sc}$ NMR (121.49 MHz, $\left.\mathrm{C}_{6} \mathrm{D}_{6}, 300 \mathrm{~K}\right): \delta=244.11$; M.p. $167-178{ }^{\circ} \mathrm{C}$; EI-MS: $\mathrm{m} / z$ (rel. int. \%) $1062\left[\mathrm{C}_{41} \mathrm{H}_{35} \mathrm{~N}_{4} \mathrm{~B}_{2} \mathrm{~F}_{20} \mathrm{O}_{2} \mathrm{Sc}^{+}, 5\right], 976\left[\mathrm{C}_{41} \mathrm{H}_{35} \mathrm{~N}_{4} \mathrm{~B}_{2} \mathrm{~F}_{20} \mathrm{O}_{2} \mathrm{Sc}^{+}-\mathrm{C}_{5} \mathrm{H}_{12} \mathrm{~N}, 50\right], 86$ $\left[\mathrm{C}_{5} \mathrm{H}_{12} \mathrm{~N}^{+}, 100\right]$

\subsubsection{Synthesis of $\mathrm{LMgBr}(21)$}

A solution of $0.125 \mathrm{~g}\left(\mathrm{HOCH}_{2}\right)_{2} \mathrm{C}\left(\mathrm{CH}_{3}\right)_{2}(2 \mathrm{mmol})$ in $5 \mathrm{~mL}$ toluene was added to a solution of 19 (obtained from reaction of $0.50 \mathrm{~g}$ (1 mmol) $\mathrm{LScBr}_{2}$ with $2 \mathrm{~mL}$ $\left(\mathrm{C}_{3} \mathrm{H}_{5}\right) \mathrm{MgBr}(1 \mathrm{M}$ in ether, $2 \mathrm{mmol})$ for a yield of $\left.25 \%\right)$ in toluene $(15 \mathrm{~mL})$. The reaction 
takes place instantaneously resulting in a brown solution that was stirred for 6 hours, concentrated to approx. $10 \mathrm{~mL}$, and $1 \mathrm{~mL}$ THF was added. Crystals of 21 were obtained after several days at $-26^{\circ} \mathrm{C}$.

Anal.: Calcd for $\mathrm{C}_{17} \mathrm{H}_{35} \mathrm{~N}_{4} \mathrm{BrMg}$ (399.70, \%): C, 51.08; H, 8.83; N, 14.02. Found: C, 49.9; $\mathrm{H}, 8.9 ; \mathrm{N}, 1.2 ;{ }^{1} \mathrm{H}$ NMR $\left(500 \mathrm{MHz}, \mathrm{C}_{6} \mathrm{D}_{6}, 300 \mathrm{~K}\right): \delta=4.74$ (s, $1 \mathrm{H}$, $\mathrm{C}(\mathrm{Me}) \mathrm{CHC}(\mathrm{Me})), 3.62$ and 2.63 br signals assigned to $16 \mathrm{H}, \mathrm{CH}_{2}, 1.80\left(\mathrm{~s}, 6 \mathrm{H}, \mathrm{CCH}_{3}\right)$, 0.72 (t, $24 \mathrm{H}, \mathrm{NCH}_{2} \mathrm{CH}_{3}$ ). M.p. $122-132{ }^{\circ} \mathrm{C}$; EI-MS: $m / z$ (rel. int. \%) 400 [LMgBr$\left.{ }^{+}, 15\right]$, $86\left[\mathrm{C}_{5} \mathrm{H}_{12} \mathrm{~N}^{+}, 100\right]$.

\subsubsection{Synthesis of $\mathrm{Lu}_{2} \mathrm{Mg}_{4} \mathrm{Cl}_{10} \mathrm{O}_{2} \cdot 6 \mathrm{THF}$ (22)}

To a solution of $\mathrm{LLuCl}_{2}(\mathbf{9})(0.50 \mathrm{~g}, 0.93 \mathrm{mmol})$ in $20 \mathrm{~mL} \mathrm{THF}, 1.85 \mathrm{~mL}$ of $\mathrm{C}_{3} \mathrm{H}_{5} \mathrm{MgCl}(2 \mathrm{M}$ in ether, $1.86 \mathrm{mmol})$ were added at $0{ }^{\circ} \mathrm{C}$. The mixture was left to react overnight while it reached room temperature. Then all volatiles were removed in vacuum and $25 \mathrm{~mL}$ of toluene were added. A precipitate was filtered off to give a green solution that was concentrated to approximately $10 \mathrm{~mL}$. Even deposited in the glove-box, the green color of the solution turned to orange.in several hours and it became turbid. The precipitate was dissolved with $2 \mathrm{ml}$ THF and the solution was kept at $-26^{\circ} \mathrm{C}$. After $3 \mathrm{~d}$ crystals of 22 were obtained $\left(0.05 \mathrm{~g}, 8.6 \%\right.$ yield reported to $\left.\mathrm{LLuCl}_{2}\right)$.

Anal. Calcd. For $\mathrm{C}_{24} \mathrm{H}_{48} \mathrm{Cl}_{10} \mathrm{Lu}_{2} \mathrm{Mg}_{4} \mathrm{O}_{8}$ (1266.32, \%): C, 22.76; H, 3.82; Found: C, 23.05; $\mathrm{H}, 3.95 ;{ }^{1} \mathrm{H}$ NMR showed only the resonances corresponding to the THF molecules.

\subsubsection{Synthesis of ( $\mathrm{LLi})_{2} \mathrm{SmI}_{2}(23)$}

To $0.50 \mathrm{~g}$ of LLi $(1.65 \mathrm{mmol})$ generated in situ ${ }^{[32]}$ toluene $(50 \mathrm{~mL})$ was added. Finally, the solution was added dropwise to a suspension of $0.65 \mathrm{~g}$ (1.65 mmol) $\mathrm{SmI}_{2}$ in toluene $(25 \mathrm{~mL})$ in a $100 \mathrm{~mL}$ Schlenk flask. Then, the reaction mixture was refluxed overnight, the suspension filtered, and concentrated to $25 \mathrm{~mL}$. After adding of a few drops of pentane, the dark brown solution was deposited at $-26^{\circ} \mathrm{C}$. Dark crystals of 23 appeared after three days, which were filtered off yielding $0.30 \mathrm{~g} 23$ (35.3\% referred to the lithium salt) 
Anal. Calcd. for $\mathrm{C}_{34} \mathrm{H}_{70} \mathrm{I}_{2} \mathrm{Li}_{2} \mathrm{~N}_{8} \mathrm{Sm}$ (1009.02, \%): C, 40.47; H, 6.99; N, 11.11; Found: C, 39.9; H, 6.6; N, 10.6; M.p. 170 - $180{ }^{\circ} \mathrm{C}$; EI-MS: $m / z$ (rel. int. \%) 574 [M $\left.{ }^{+}-\mathrm{I}, 4\right], 86$ $\left[\mathrm{C}_{5} \mathrm{H}_{12} \mathrm{~N}^{+}, 100\right]$.

\subsubsection{Synthesis of $(\mathrm{LLi})_{2} \mathrm{YbI}_{2}(24)$}

To $0.40 \mathrm{~g}$ (2.3 mmol) Yb turnings in $25 \mathrm{~mL}$ THF $0.45 \mathrm{~g}, 0.30 \mathrm{~mL}(2.3 \mathrm{mmol})$ neopentyl iodide were added. After $1 \mathrm{~d}$ stirring at room temperature, the unreacted $\mathrm{Yb}$ was filtered off and the red solution was added dropwise to a solution of $2 \mathrm{mmol}(0.6 \mathrm{~g})$ LLi in THF $(25 \mathrm{~mL})$ at $-78^{\circ} \mathrm{C}$. The solution turned dark green and it was allowed to reach room temperature where it was maintained overnight. Then the solvent was removed in vacuo, $30 \mathrm{~mL}$ toluene added, and the suspension filtered. After one week at $26{ }^{\circ} \mathrm{C}$ dark green crystals of $\mathbf{2 4}$ appeared and they were filtered yielding $0.50 \mathrm{~g}$ of $\mathbf{2 4}$ (in two crops, $21.1 \%$ ).

Anal. Calcd. for $\mathrm{C}_{37} \mathrm{H}_{70} \mathrm{I}_{2} \mathrm{Li}_{2} \mathrm{~N}_{8} \mathrm{Yb}$ (1067.74, \%): C, 39.58; H, 6.84; N, 10.86; Found: C, 39.45; H, 6.50; N, 10.46; M.p. $200-205{ }^{\circ} \mathrm{C}$; EI-MS: $m / z$ (rel. int. \%) 607 [M+-I, 5], 86 $\left[\mathrm{C}_{5} \mathrm{H}_{12} \mathrm{~N}^{+}, 100\right]$.

\subsection{NMR and GC-MS Experiments}

4.4.5.1. The synthesis of compound 19 was repeated in one side of an H-form tube with an amount five times as small as than in the procedure described above in $2 \mathrm{~mL}$ THF- $\mathrm{d}_{8}$. Instead of removing the THF in the second step, it was condensed in the other side of the tube and the solution was transfered inside a dry-box to an NMR tube and in a recipient for the GC-MS experiments.

4.4.5.2. The reaction of 19 with $\left(\mathrm{HOCH}_{2}\right)_{2} \mathrm{C}\left(\mathrm{CH}_{3}\right)_{2}$ was repeated in a NMR tube with

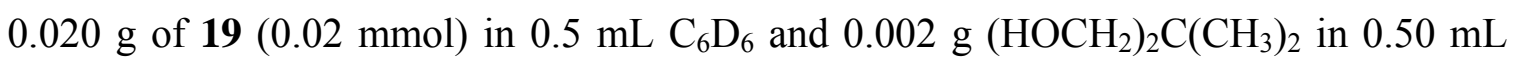
$\mathrm{C}_{6} \mathrm{D}_{6}$ charged inside a dry-box. The ${ }^{1} \mathrm{H}-\mathrm{NMR}\left(500 \mathrm{MHz}, \mathrm{C}_{6} \mathrm{D}_{6}, 300 \mathrm{~K}\right)$ spectrum was recorded after $5 \mathrm{~min}$ and after $24 \mathrm{~h}$. 


\section{Handling and Disposal of Solvents and Residual Waste}

1. The recovered solvents were condensed into cold-traps under vacuum, and stored for disposal.

2. Used NMR solvents were disposed as heavy metal wastes.

3. The heavy metal residues were dissolved in nitric acid and after neutralization were stored in the containers for heavy metal wastes.

4. Drying agents such as $\mathrm{KOH}, \mathrm{CaCl}_{2}, \mathrm{CaH}_{2}$, and $\mathrm{P}_{4} \mathrm{O}_{10}$ were hydrolyzed and disposed as acid or base wastes.

5. If it was possible, $\mathrm{Na}$ metal used for drying solvents was collected for recycling. ${ }^{[119]}$ The non-reusable sodium metal was hydrolyzed in cold ethanol and used for cleaning glassware in the alkali bath.

6. Ethanol and acetone used for cold baths were subsequently used for cleaning glassware.

7. The residue of the alkali bath used for cleaning glassware was disposed into the container for basic wastes.

8. The residue of the acid bath used for cleaning glassware was neutralized with $\mathrm{Na}_{2} \mathrm{CO}_{3}$ and washed off in the water drainage system. 
Amounts of various types of disposable wastes generated during this work:

Metal containing wastes

Solvent wastes

Acid wastes

Base wastes
$20 \mathrm{~L}$,

$60 \mathrm{~L}$,

$25 \mathrm{~L}$,

$25 \mathrm{~L}$. 


\section{Crystal Data and Refinement Details}

\section{Table C1. Crystal data and structure refinement for $\mathbf{5 a}$}

Empirical formula

Formula weight

Temperature $(\mathrm{K})$

$\lambda(\AA)$

Crystal system

Space group

Unit cell dimensions $\left(\AA,^{\circ}\right)$

Volume $\left(\AA^{3}\right), Z$

Density (calculated) $\left(\mathrm{g} / \mathrm{cm}^{3}\right)$

Absorption coefficient $\left(\mathrm{mm}^{-1}\right)$

$\mathrm{F}(000)$

Crystal size $\left(\mathrm{mm}^{3}\right)$

$\theta$ range for data collection

Index ranges

Reflections collected

Independent reflections

Completeness to $\theta=24.72^{\circ}$

Absorption correction

Refinement method

Data / restraints / parameters

Goodness-of-fit on $F^{2}$

Final $R$ indices $[I>2 \sigma(I)]$

$R$ indices (all data)

Largest diff. peak and hole $\left(\mathrm{e} \cdot \AA^{-3}\right)$
$\mathrm{C}_{17} \mathrm{H}_{35} \mathrm{Cl}_{2} \mathrm{~N}_{4} \mathrm{Sc}$

411.35

133(2)

0.71073

Monoclinic

$P 2_{1} / c$

$a=15.309(15)$

$b=10.912(7)$

$\beta=107.15(8)$

$c=13.049(13)$

2083.0(3), 4

1.312

0.617

880

$0.3 \times 0.3 \times 0.2$

2.33 to 24.72

$-17 \leq h \leq 17,-12 \leq k \leq 10,-12 \leq l \leq 15$

14056

$3461\left[R_{\text {int }}=0.0854\right]$

$97.7 \%$

Empirical

Full-matrix least-squares on $F^{2}$

$3461 / 0 / 223$

1.026

$R_{1}=0.0357, w R_{2}=0.0827$

$R_{1}=0.0520, w R_{2}=0.0913$

0.400 and -0.590 
Table C2. Crystal data and structure refinement for $\mathbf{5 b}$

Empirical formula

Formula weight

Temperature $(\mathrm{K})$

$\lambda(\AA)$

Crystal system

Space group

Unit cell dimensions $\left(\AA,^{\circ}\right)$

Volume $\left(\AA^{3}\right), Z$

Density (calculated) $\left(\mathrm{g} / \mathrm{cm}^{3}\right)$

Absorption coefficient $\left(\mathrm{mm}^{-1}\right)$

$\mathrm{F}(000)$

Crystal size $\left(\mathrm{mm}^{3}\right)$

$\theta$ range for data collection

Index ranges

Reflections collected

Independent reflections

Completeness to $\theta=28.28^{\circ}$

Absorption correction

Refinement method

Data / restraints / parameters

Goodness-of-fit on $F^{2}$

Final $R$ indices $[I>2 \sigma(I)]$

$R$ indices (all data)

Largest diff. peak and hole $\left(\mathrm{e} \cdot \AA^{-3}\right)$
$\mathrm{C}_{17} \mathrm{H}_{35} \mathrm{Cl}_{2} \mathrm{~N}_{4} \mathrm{Sc}$

411.35

133(2)

0.71073

orthorhombic

$P_{c a 2}$

$a=20.340(9)$

$b=8.094(3)$

$c=13.049(7)$

2148.51(17), 4

1.272

0.598

880

$0.3 \times 0.3 \times 0.2$

2.00 to 24.82

$-23 \leq h \leq 24,-9 \leq k \leq 9,-15 \leq l \leq 15$

36094

$3696\left[R_{\text {int }}=0.0955\right]$

$99.6 \%$

Empirical

Full-matrix least-squares on $F^{2}$

3696 / 1 / 223

1.064

$R_{1}=0.0520, w R_{2}=0.1562$

$R_{1}=0.0539, w R_{2}=0.1587$

0.582 and -1.237 
Table C3. Crystal data and structure refinement for $\mathbf{6}$

Empirical formula

Formula weight

Temperature $(\mathrm{K})$

$\lambda(\AA)$

Crystal system

Space group

Unit cell dimensions $\left(\AA,^{\circ}\right)$

Volume $\left(\AA^{3}\right), Z$

Density (calculated) $\left(\mathrm{g} / \mathrm{cm}^{3}\right)$

Absorption coefficient $\left(\mathrm{mm}^{-1}\right)$

$\mathrm{F}(000)$

Crystal size $\left(\mathrm{mm}^{3}\right)$

$\theta$ range for data collection

Index ranges

Reflections collected

Independent reflections

Completeness to $\theta=24.71^{\circ}$

Absorption correction

Refinement method

Data / restraints / parameters

Goodness-of-fit on $F^{2}$

Final $R$ indices $[I>2 \sigma(I)]$

$R$ indices (all data)

Largest diff. peak and hole $\left(\mathrm{e} \cdot \AA^{-3}\right)$
$\mathrm{C}_{17} \mathrm{H}_{35} \mathrm{Br}_{2} \mathrm{~N}_{4} \mathrm{Sc}$

500.27

133(2) K

0.71073

monoclinic

$P 2{ }_{1} / c$

$a=15.767(7)$

$b=10.801(3)$

$\beta=107.61(4)$

$c=13.365(6)$

2169.63(15), 4

1.532

4.029

880

$0.3 \times 0.4 \times 0.3$

2.32 to 24.71

$-18 \leq h \leq 18,-12 \leq k \leq 12,-15 \leq l \leq 15$

43718

$3702\left[R_{\text {int }}=0.0657\right]$

$99.9 \%$

Empirical

Full-matrix least-squares on $F^{2}$

3702 / 0 / 223

1.070

$R_{1}=0.0176, w R_{2}=0.0411$

$R_{1}=0.0196, w R_{2}=0.0417$

0.294 and -0.201 
Table C4. Crystal data and structure refinement for $\mathbf{8}$

\begin{tabular}{ll}
\hline Empirical formula & $\mathrm{C}_{17} \mathrm{H}_{35} \mathrm{Br}_{2} \mathrm{~N}_{4} \mathrm{Y}^{\cdot} \mathrm{C}_{7} \mathrm{H}_{8}$ \\
Formula weight & 636.35 \\
Temperature $(\mathrm{K})$ & $133(2) \mathrm{K}$ \\
$\lambda(\AA)$ & 0.71073 \\
Crystal system & monoclinic \\
Space group & $P 2_{1} / n$ \\
Unit cell dimensions $\left(\AA,^{\circ}\right)$ & $a=7.829(8)$ \\
& $b=8.379(11)$ \\
& $c=42.03(4)$ \\
Volume $\left(\AA^{3}\right), Z$ & $2750.3(5), 4$ \\
Density (calculated) $\left(\mathrm{g} / \mathrm{cm}^{3}\right)$ & 1.537 \\
Absorption coefficient $\left(\mathrm{mm}^{-1}\right)$ & 5.044 \\
$\mathrm{~F}(000)$ & 1296 \\
Crystal size (mm $\left.{ }^{3}\right)$ & $0.2 \times 0.4 \times 0.4$ \\
$\theta$ range for data collection & 2.48 to 24.09 \\
Index ranges & $-8 \leq h \leq 7,-8 \leq k \leq 9,-40 \leq l \leq 48$ \\
Reflections collected & 4034 \\
Independent reflections & $3702\left[R_{\text {int }}=0.092 .6\right]$ \\
Completeness to $\theta=24.09^{\circ}$ & $99.9 \%$ \\
Absorption correction & Empirical \\
Refinement method & Full-matrix least-squares on $F^{2}$ \\
Data $/$ restraints / parameters & $4034 / 0 / 288$ \\
Goodness-of-fit on $F^{2}$ & 1.085 \\
Final $R$ indices $[I>2 \sigma(I)]$ & $R_{1}=0.0551, w R_{2}=0.1315$ \\
$R$ indices (all data) & $R_{1}=0.0764, w R_{2}=0.1387$ \\
Largest diff. peak and hole $\left(\mathrm{e} \cdot \AA^{-3}\right)$ & 0.524 and -0.760 \\
\hline &
\end{tabular}


Table C5. Crystal data and structure refinement for 12

\begin{tabular}{|c|c|}
\hline Empirical formula & $\mathrm{C}_{34} \mathrm{H}_{70} \mathrm{Cl}_{2} \mathrm{LaLiN}_{8}$ \\
\hline Formula weight & 807.73 \\
\hline Temperature (K) & $133(2) \mathrm{K}$ \\
\hline$\lambda(\AA)$ & 0.71073 \\
\hline Crystal system & monoclinic \\
\hline Space group & $P 2_{1} / n$ \\
\hline \multirow[t]{3}{*}{ Unit cell dimensions $\left(\AA,^{\circ}\right)$} & $a=16.422(6)$ \\
\hline & $b=14.941(4)$ \\
\hline & $c=17.494(6)$ \\
\hline Volume $\left(\AA^{3}\right), Z$ & $4079.0(2), 4$ \\
\hline Density (calculated) $\left(\mathrm{g} / \mathrm{cm}^{3}\right)$ & 1.315 \\
\hline Absorption coefficient $\left(\mathrm{mm}^{-1}\right)$ & 1.211 \\
\hline $\mathrm{F}(000)$ & 1696 \\
\hline Crystal size $\left(\mathrm{mm}^{3}\right)$ & $0.4 \times 0.3 \times 0.4$ \\
\hline$\theta$ range for data collection & 1.83 to 24.71 \\
\hline Index ranges & $-19 \leq h \leq 19,-17 \leq k \leq 17,-19 \leq l \leq 20$ \\
\hline Reflections collected & 66871 \\
\hline Independent reflections & $6960\left[R_{\mathrm{int}}=0.0818\right]$ \\
\hline Completeness to $\theta=24.71^{\circ}$ & $99.9 \%$ \\
\hline Absorption correction & Empirical \\
\hline Refinement method & Full-matrix least-squares on $F^{2}$ \\
\hline Data / restraints / parameters & $6960 / 0 / 466$ \\
\hline Goodness-of-fit on $F^{2}$ & 1.029 \\
\hline Final $R$ indices $[I>2 \sigma(I)]$ & $R_{1}=0.0236, w R_{2}=0.0606$ \\
\hline$R$ indices (all data) & $R_{1}=0.0271, w R_{2}=0.0616$ \\
\hline Largest diff. peak and hole $\left(\mathrm{e} \cdot \AA^{-3}\right)$ & 0.605 and -0.433 \\
\hline
\end{tabular}


Table C6. Crystal data and structure refinement for $\mathbf{1 3}$

Empirical formula

Formula weight

Temperature $(\mathrm{K})$

$\lambda(\AA)$

Crystal system

Space group

Unit cell dimensions $\left(\AA,^{\circ}\right)$

Volume $\left(\AA^{3}\right), Z$

Density (calculated) $\left(\mathrm{g} / \mathrm{cm}^{3}\right)$

Absorption coefficient $\left(\mathrm{mm}^{-1}\right)$

$\mathrm{F}(000)$

Crystal size $\left(\mathrm{mm}^{3}\right)$

$\theta$ range for data collection

Index ranges

Reflections collected

Independent reflections

Completeness to $\theta=24.76^{\circ}$

Absorption correction

Refinement method

Data / restraints / parameters

Goodness-of-fit on $F^{2}$

Final $R$ indices $[I>2 \sigma(I)]$

$R$ indices (all data)

Largest diff. peak and hole $\left(\mathrm{e} \cdot \AA^{-3}\right)$
$\mathrm{C}_{34} \mathrm{H}_{70} \mathrm{Cl}_{2} \mathrm{CeLiN}_{8}$

808.94

133(2) K

0.71073

monoclinic

$P 2_{1} / n$

$a=16.423(6)$

$b=14.942(4)$

$\beta=108.18(3)$

$c=17.495(6)$

4079.0(2), 4

1.317

1.280

1700

$0.3 \times 0.3 \times 0.2$

1.83 to 24.76

$-19 \leq h \leq 19,-13 \leq k \leq 17,-20 \leq l \leq 20$

33296

$6948\left[R_{\text {int }}=0.0912\right]$

$99.2 \%$

Empirical

Full-matrix least-squares on $F^{2}$

6948 / 0 / 466

0.851

$R_{1}=0250, w R_{2}=0.0646$

$R_{1}=0.0303, w R_{2}=0.0662$

0.618 and -0.775 
Table C7. Crystal data and structure refinement for $\mathbf{1 4}$

\begin{tabular}{|c|c|}
\hline Empirical formula & $\mathrm{C}_{60} \mathrm{H}_{120} \mathrm{~N}_{10} \mathrm{Sc}_{2} \mathrm{Si}_{4} \cdot 2 \mathrm{C}_{7} \mathrm{H}_{8}$ \\
\hline Formula weight & 1183.94 \\
\hline Temperature (K) & $133(2) \mathrm{K}$ \\
\hline$\lambda(\AA)$ & 0.71073 \\
\hline Crystal system & monoclinic \\
\hline Space group & $P 2_{1} / n$ \\
\hline \multirow[t]{3}{*}{ Unit cell dimensions $\left(\AA,^{\circ}\right)$} & $a=16.313(7)$ \\
\hline & $b=20.475(9)$ \\
\hline & $c=22.155(10)$ \\
\hline Volume $\left(\AA^{3}\right), Z$ & $7026.5(5), 4$ \\
\hline Density (calculated) $\left(\mathrm{g} / \mathrm{cm}^{3}\right)$ & 1.119 \\
\hline Absorption coefficient $\left(\mathrm{mm}^{-1}\right)$ & 0.303 \\
\hline $\mathrm{F}(000)$ & 2592 \\
\hline Crystal size $\left(\mathrm{mm}^{3}\right)$ & $0.3 \times 0.2 \times 0.2$ \\
\hline$\theta$ range for data collection & 1.65 to 24.81 \\
\hline Index ranges & $-18 \leq h \leq 19,-24 \leq k \leq 24,-26 \leq l \leq 26$ \\
\hline Reflections collected & 85650 \\
\hline Independent reflections & $12041\left[R_{\mathrm{int}}=0.0607\right]$ \\
\hline Completeness to $\theta=24.81^{\circ}$ & $99.4 \%$ \\
\hline Absorption correction & Empirical \\
\hline Refinement method & Full-matrix least-squares on $F^{2}$ \\
\hline Data / restraints / parameters & $12041 / 0 / 743$ \\
\hline Goodness-of-fit on $F^{2}$ & 1.070 \\
\hline Final $\mathrm{R}$ indices $[I>2 \sigma(I)]$ & $R_{1}=0.0409, w R_{2}=0.0963$ \\
\hline $\mathrm{R}$ indices (all data) & $R_{1}=0.0632, w R_{2}=0.1002$ \\
\hline Largest diff. peak and hole $\left(\mathrm{e} \cdot \AA^{-3}\right)$ & 0.955 and -0.273 \\
\hline
\end{tabular}


Table C8. Crystal data and structure refinement for 15

Empirical formula

Formula weight

Temperature $(\mathrm{K})$

$\lambda(\AA)$

Crystal system

Space group

Unit cell dimensions $\left(\AA,^{\circ}\right)$

Volume $\left(\AA^{3}\right), Z$

Density (calculated) $\left(\mathrm{g} / \mathrm{cm}^{3}\right)$

Absorption coefficient $\left(\mathrm{mm}^{-1}\right)$

$\mathrm{F}(000)$

Crystal size $\left(\mathrm{mm}^{3}\right)$

$\theta$ range for data collection

Index ranges

Reflections collected

Independent reflections

Completeness to $\theta=24.71^{\circ}$

Absorption correction

Refinement method

Data / restraints / parameters

Goodness-of-fit on $F^{2}$

Final $R$ indices $[I>2 \sigma(I)]$

$R$ indices (all data)

Largest diff. peak and hole $\left(\mathrm{e} \cdot \AA^{-3}\right)$
$\mathrm{C}_{19} \mathrm{H}_{35} \mathrm{~F}_{6} \mathrm{~N}_{4} \mathrm{O}_{6} \mathrm{~S}_{2} \mathrm{Sc}$

638.59

133(2) K

0.71073

orthorhombic

Pnma

$a=21.687(11)$

$b=14.427(11)$

$c=8.928(5)$

2793.6(3), 4

1.518

0.494

1328

$0.3 \times 0.4 \times 0.3$

1.88 to 24.71

$-25 \leq h \leq 25,-16 \leq k \leq 16,-10 \leq l \leq 10$

33172

$2482\left[R_{\mathrm{int}}=0.0519\right]$

$100.0 \%$

Empirical

Full-matrix least-squares on $F^{2}$

2482 / 0 / 190

1.030

$R_{1}=0.0280, w R_{2}=0.0729$

$R_{1}=0.0355, w R_{2}=0.0749$

0.403 and -0.407 
Table C9. Crystal data and structure refinement for $\mathbf{1 6}$

\begin{tabular}{|c|c|}
\hline Empirical formula & $\mathrm{C}_{23} \mathrm{H}_{53} \mathrm{Cl}_{2} \mathrm{~F}_{2} \mathrm{~N}_{4} \mathrm{ScSn}_{2}$ \\
\hline Formula weight & 776.93 \\
\hline Temperature $(\mathrm{K})$ & $133(2) \mathrm{K}$ \\
\hline$\lambda(\AA)$ & 0.71073 \\
\hline Crystal system & monoclinic \\
\hline Space group & $C 2 / c$ \\
\hline \multirow[t]{3}{*}{ Unit cell dimensions $\left(\AA,^{\circ}\right)$} & $a=17.190(3)$ \\
\hline & $b=17.220(5)$ \\
\hline & $c=18.408(4)$ \\
\hline Volume $\left(\AA^{3}\right), Z$ & $3269.3(11), 4$ \\
\hline Density (calculated) $\left(\mathrm{g} / \mathrm{cm}^{3}\right)$ & 1.578 \\
\hline Absorption coefficient $\left(\mathrm{mm}^{-1}\right)$ & 1.911 \\
\hline $\mathrm{F}(000)$ & 1568 \\
\hline Crystal size $\left(\mathrm{mm}^{3}\right)$ & $0.2 \times 0.3 \times 0.2$ \\
\hline$\theta$ range for data collection & 2.29 to 22.49 \\
\hline Index ranges & $-8 \leq h \leq 11,-18 \leq k \leq 11,-19 \leq l \leq 19$ \\
\hline Reflections collected & 3750 \\
\hline Independent reflections & $1800\left[R_{\text {int }}=0.1126\right]$ \\
\hline Completeness to $\theta=22.49^{\circ}$ & $84.1 \%$ \\
\hline Absorption correction & Empirical \\
\hline Refinement method & Full-matrix least-squares on $F^{2}$ \\
\hline Data / restraints / parameters & $1800 / 0 / 161$ \\
\hline Goodness-of-fit on $F^{2}$ & 1.026 \\
\hline Final $R$ indices $[I>2 \sigma(I)]$ & $R_{1}=0.0597, w R_{2}=0.1470$ \\
\hline$R$ indices (all data) & $R_{1}=0.0657, w R_{2}=0.1504$ \\
\hline Largest diff. peak and hole $\left(\mathrm{e} \cdot \AA^{-3}\right)$ & 2.211 and -1.418 \\
\hline
\end{tabular}


Table C10. Crystal data and structure refinement for $\mathbf{1 7 a}$

Empirical formula

Formula weight

Temperature $(\mathrm{K})$

$\lambda(\AA)$

Crystal system

Space group

Unit cell dimensions $\left(\AA,^{\circ}\right)$

Volume $\left(\AA^{3}\right), Z$

Density (calculated) $\left(\mathrm{g} / \mathrm{cm}^{3}\right)$

Absorption coefficient $\left(\mathrm{mm}^{-1}\right)$

$\mathrm{F}(000)$

Crystal size $\left(\mathrm{mm}^{3}\right)$

$\theta$ range for data collection

Index ranges

Reflections collected

Independent reflections

Completeness to $\theta=27.49^{\circ}$

Absorption correction

Refinement method

Data / restraints / parameters

Goodness-of-fit on $F^{2}$

Final $R$ indices $[I>2 \sigma(I)]$

$R$ indices (all data)

Largest diff. peak and hole $\left(\mathrm{e} \cdot \AA^{-3}\right)$
$\mathrm{C}_{23} \mathrm{H}_{53} \mathrm{Br}_{2} \mathrm{~F}_{2} \mathrm{~N}_{4} \mathrm{ScSn}_{2}$

865.85

133(2) K

0.71073

triclinic

$$
\begin{array}{ll}
P \overline{1} & \\
a=9.832(3) & \alpha=97.91(3) \\
b=10.305(3) & \beta=99.75(3) \\
c=18.705(5) & \gamma=114.19(3)
\end{array}
$$

1658.0(8), 2

1.734

4.133

856

$0.1 \times 0.2 \times 0.2$

2.23 to 27.49

$-12 \leq h \leq 12,-13 \leq k \leq 7,-24 \leq l \leq 24$

25903

$7516\left[R_{\text {int }}=0.0760\right]$

$98.8 \%$

Empirical

Full-matrix least-squares on $F^{2}$

$7516 / 0 / 320$

0.982

$R_{1}=0.0455, w R_{2}=0.0931$

$R_{1}=0.0667, w R_{2}=0.0993$

1.137 and -1.048 
Table C11. Crystal data and structure refinement for $\mathbf{1 7 b}$

\begin{tabular}{|c|c|}
\hline Empirical formula & $\mathrm{C}_{23} \mathrm{H}_{53} \mathrm{Br}_{2} \mathrm{~F}_{2} \mathrm{~N}_{4} \mathrm{ScSn}_{2}$ \\
\hline Formula weight & 865.85 \\
\hline Temperature (K) & $133(2) \mathrm{K}$ \\
\hline$\lambda(\AA)$ & 0.71073 \\
\hline Crystal system & monoclinic \\
\hline Space group & $C 2 / c$ \\
\hline \multirow[t]{3}{*}{ Unit cell dimensions $\left(\AA,^{\circ}\right)$} & $a=10.801(2)$ \\
\hline & $b=17.220(5)$ \\
\hline & $c=18.512(5)$ \\
\hline Volume $\left(\AA^{3}\right), Z$ & $3342.7(15), 4$ \\
\hline Density (calculated) $\left(\mathrm{g} / \mathrm{cm}^{3}\right)$ & 1.721 \\
\hline Absorption coefficient $\left(\mathrm{mm}^{-1}\right)$ & 4.100 \\
\hline $\mathrm{F}(000)$ & 1712 \\
\hline Crystal size $\left(\mathrm{mm}^{3}\right)$ & $0.1 \times 0.2 \times 0.2$ \\
\hline$\theta$ range for data collection & 2.27 to 27.53 \\
\hline Index ranges & $-14 \leq h \leq 11,-22 \leq k \leq 22,-24 \leq l \leq 23$ \\
\hline Reflections collected & 41276 \\
\hline Independent reflections & $3827\left[R_{\mathrm{int}}=0.0578\right]$ \\
\hline Completeness to $\theta=27.49^{\circ}$ & $99.4 \%$ \\
\hline Absorption correction & Empirical \\
\hline Refinement method & Full-matrix least-squares on $F^{2}$ \\
\hline Data / restraints / parameters & $3827 / 0 / 161$ \\
\hline Goodness-of-fit on $F^{2}$ & 1.159 \\
\hline Final $R$ indices $[I>2 \sigma(I)]$ & $R_{1}=0.0573, w R_{2}=0.1418$ \\
\hline$R$ indices (all data) & $R_{1}=0.0678, w R_{2}=0.1616$ \\
\hline Largest diff. peak and hole $\left(\mathrm{e} \cdot \AA^{-3}\right)$ & 2.723 and -4.110 \\
\hline
\end{tabular}


Table C12. Crystal data and structure refinement for $\mathbf{1 8}$

Empirical formula

Formula weight

Temperature $(\mathrm{K})$

$\lambda(\AA)$

Crystal system

Space group

Unit cell dimensions $\left(\AA,^{\circ}\right)$

Volume $\left(\AA^{3}\right), Z$

Density (calculated) $\left(\mathrm{g} / \mathrm{cm}^{3}\right)$

Absorption coefficient $\left(\mathrm{mm}^{-1}\right)$

$\mathrm{F}(000)$

Crystal size $\left(\mathrm{mm}^{3}\right)$

$\theta$ range for data collection

Index ranges

Reflections collected

Independent reflections

Completeness to $\theta=24.82^{\circ}$

Absorption correction

Refinement method

Data / restraints / parameters

Goodness-of-fit on $F^{2}$

Final $R$ indices $[I>2 \sigma(I)]$

$R$ indices (all data)

Largest diff. peak and hole $\left(\mathrm{e} \cdot \AA^{-3}\right)$

\section{$\mathrm{C}_{44} \mathrm{H}_{102} \mathrm{~N}_{12} \mathrm{Si}_{4} \mathrm{Y}_{2} \cdot \mathrm{C}_{7} \mathrm{H}_{8}$}

1181.65

133(2)

0.71073

monoclinic

$P 2_{1} / n$

$a=11.829(2)$

$b=12.995(3)$

$\beta=103.00(3)$

$c=22.078(4)$

3306.7(11), 4

1.186

1.859

1266

$0.3 \times 0.3 \times 0.2$

1.81 to 24.82

$-13 \leq h \leq 13,-15 \leq k \leq 15,-25 \leq l \leq 26$

17688

$5560\left[R_{\mathrm{int}}=0.0832\right]$

$97.5 \%$

Empirical

Full-matrix least-squares on $F^{2}$

5560 / $242 / 331$

0.968

$R_{1}=0.0375, w R_{2}=0.0899$

$R_{1}=0.0472, w R_{2}=0.0937$

0.739 and -0.699 
Table C13. Crystal data and structure refinement for 19

\begin{tabular}{|c|c|}
\hline Empirical formula & $\left(\mathrm{C}_{17} \mathrm{H}_{35} \mathrm{~N}_{4}\right)_{2} \mathrm{ScMg}_{2} \mathrm{Br}_{3} \cdot \mathrm{C}_{7} \mathrm{H}_{8}$ \\
\hline Formula weight & 1016.42 \\
\hline Temperature (K) & $133(2) \mathrm{K}$ \\
\hline$\lambda(\AA)$ & 0.71073 \\
\hline Crystal system & orthorhombic \\
\hline Space group & $\mathrm{Cmcm}$ \\
\hline \multirow[t]{3}{*}{ Unit cell dimensions $\left(\AA,^{\circ}\right)$} & $a=21.576(12)$ \\
\hline & $b=12.970(7)$ \\
\hline & $c=17.734(8)$ \\
\hline Volume $\left(\AA^{3}\right), Z$ & $4962.8(4), 4$ \\
\hline Density (calculated) $\left(\mathrm{g} / \mathrm{cm}^{3}\right)$ & 1.360 \\
\hline Absorption coefficient $\left(\mathrm{mm}^{-1}\right)$ & 2.625 \\
\hline $\mathrm{F}(000)$ & 2120 \\
\hline Crystal size $\left(\mathrm{mm}^{3}\right)$ & $0.2 \times 0.2 \times 0.2$ \\
\hline$\theta$ range for data collection & 1.83 to 24.71 \\
\hline Index ranges & $-25 \leq h \leq 25,-15 \leq k \leq 14,-20 \leq l \leq 18$ \\
\hline Reflections collected & 26177 \\
\hline Independent reflections & $2256\left[R_{\mathrm{int}}=0.0720\right]$ \\
\hline Completeness to $\theta=24.71^{\circ}$ & $99.9 \%$ \\
\hline Absorption correction & Empirical \\
\hline Refinement method & Full-matrix least-squares on $F^{2}$ \\
\hline Data / restraints / parameters & $2256 / 0 / 199$ \\
\hline Goodness-of-fit on $F^{2}$ & 1.107 \\
\hline Final $R$ indices $[I>2 \sigma(I)]$ & $R_{1}=0.0315, w R_{2}=0.0849$ \\
\hline$R$ indices (all data) & $R_{1}=0.0346, w R_{2}=0.0867$ \\
\hline Largest diff. peak and hole $\left(\mathrm{e} \cdot \AA^{-3}\right)$ & 0.946 and -0.608 \\
\hline
\end{tabular}


Table C14. Crystal data and structure refinement for 20

Empirical formula

Formula weight

Temperature $(\mathrm{K})$

$\lambda(\AA)$

Crystal system

Space group

Unit cell dimensions $\left(\AA,^{\circ}\right)$

Volume $\left(\AA^{3}\right), Z$

Density (calculated) $\left(\mathrm{g} / \mathrm{cm}^{3}\right)$

Absorption coefficient $\left(\mathrm{mm}^{-1}\right)$

$\mathrm{F}(000)$

Crystal size $\left(\mathrm{mm}^{3}\right)$

$\theta$ range for data collection

Index ranges

Reflections collected

Independent reflections

Completeness to $\theta=23.21^{\circ}$

Absorption correction

Refinement method

Data / restraints / parameters

Goodness-of-fit on $F^{2}$

Final $R$ indices $[I>2 \sigma(I)]$

$R$ indices (all data)

Largest diff. peak and hole $\left(\mathrm{e} \cdot \AA^{-3}\right)$

\section{$\mathrm{C}_{41} \mathrm{H}_{35} \mathrm{~B}_{2} \mathrm{~F}_{20} \mathrm{~N}_{4} \mathrm{O}_{2} \mathrm{Sc} \cdot \mathrm{C}_{7} \mathrm{H}_{8}$}

1154.28

173(2)

1.54178

triclinic
$P \overline{1}$
$a=10.865(2)$
$\alpha=71.83(3)$
$b=13.518(3)$
$\beta=85.12(3)$
$c=19.173(4)$
$\gamma=69.11(3)$

2498.6(9), 4

1.534

0.266

1172

$0.1 \times 0.2 \times 0.1$

1.12 to 23.21

$-11 \leq h \leq 12,-13 \leq k \leq 14,0 \leq l \leq 21$

12159

$12159\left[R_{\text {int }}=0.221\right]$

$98.3 \%$

Empirical

Full-matrix least-squares on $F^{2}$

12159 / 3 / 767

1.084

$R_{1}=0.0453, w R_{2}=0.1363$

$R_{1}=0.0485, w R_{2}=0.1402$

0.327 and -0.438 
Table C15. Crystal data and structure refinement for 21

\begin{tabular}{|c|c|}
\hline Empirical formula & $\mathrm{C}_{17} \mathrm{H}_{35} \mathrm{BrMgN}_{4} \cdot \mathrm{C}_{7} \mathrm{H}_{8}$ \\
\hline Formula weight & 490.25 \\
\hline Temperature $(\mathrm{K})$ & $293(2)$ \\
\hline$\lambda(\AA)$ & 0.71073 \\
\hline Crystal system & monoclinic \\
\hline Space group & $P 2_{1} / c$ \\
\hline \multirow[t]{3}{*}{ Unit cell dimensions $\left(\AA,^{\circ}\right)$} & $a=17.508(4)$ \\
\hline & $b=7.297(14)$ \\
\hline & $c=19.674(4)$ \\
\hline Volume $\left(\AA^{3}\right), Z$ & $2354.4(8), 4$ \\
\hline Density (calculated) $\left(\mathrm{g} / \mathrm{cm}^{3}\right)$ & 1.258 \\
\hline Absorption coefficient $\left(\mathrm{mm}^{-1}\right)$ & 1.784 \\
\hline $\mathrm{F}(000)$ & 948 \\
\hline Crystal size $\left(\mathrm{mm}^{3}\right)$ & $0.3 \times 0.2 \times 0.2$ \\
\hline$\theta$ range for data collection & 2.21 to 27.10 \\
\hline Index ranges & $-22 \leq h \leq 21,0 \leq k \leq 9,0 \leq l \leq 25$ \\
\hline Reflections collected & 23318 \\
\hline Independent reflections & $5067\left[R_{\mathrm{int}}=0.0768\right]$ \\
\hline Completeness to $\theta=23.21^{\circ}$ & $97.5 \%$ \\
\hline Absorption correction & Empirical \\
\hline Refinement method & Full-matrix least-squares on $F^{2}$ \\
\hline Data / restraints / parameters & $5067 / 0 / 266$ \\
\hline Goodness-of-fit on $F^{2}$ & 1.084 \\
\hline Final $R$ indices $[I>2 \sigma(I)]$ & $R_{1}=0.0567, w R_{2}=0.1372$ \\
\hline$R$ indices (all data) & $R_{1}=0.0874, w R_{2}=0.1570$ \\
\hline Largest diff. peak and hole $\left(\mathrm{e} \cdot \AA^{-3}\right)$ & 1.966 and -0.596 \\
\hline
\end{tabular}


Table C16. Crystal data and structure refinement for 22

\begin{tabular}{|c|c|c|}
\hline Empirical formula & \multicolumn{2}{|c|}{$\mathrm{C}_{24} \mathrm{H}_{48} \mathrm{Cl}_{10} \mathrm{Lu}_{2} \mathrm{Mg}_{4} \mathrm{O}_{8}$} \\
\hline Formula weight & \multicolumn{2}{|l|}{1266.30} \\
\hline Temperature $(\mathrm{K})$ & \multicolumn{2}{|l|}{$173(2)$} \\
\hline$\lambda(\AA)$ & \multicolumn{2}{|l|}{0.71073} \\
\hline Crystal system & \multicolumn{2}{|l|}{ triclinic } \\
\hline Space group & \multicolumn{2}{|l|}{$P \overline{1}$} \\
\hline \multirow[t]{3}{*}{ Unit cell dimensions $\left(\AA,^{\circ}\right)$} & $a=10.789(5)$ & $\alpha=75.92(6)$ \\
\hline & $b=11.305(5)$ & $\beta=65.76(6)$ \\
\hline & $c=11.105(5)$ & $\gamma=69.48(6)$ \\
\hline Volume $\left(\AA^{3}\right), Z$ & \multicolumn{2}{|l|}{ 1095.4(8), 1} \\
\hline Density (calculated) $\left(\mathrm{g} / \mathrm{cm}^{3}\right)$ & \multicolumn{2}{|l|}{1.920} \\
\hline Absorption coefficient $\left(\mathrm{mm}^{-1}\right)$ & \multicolumn{2}{|l|}{5.186} \\
\hline $\mathrm{F}(000)$ & \multicolumn{2}{|l|}{616} \\
\hline Crystal size $\left(\mathrm{mm}^{3}\right)$ & \multicolumn{2}{|l|}{$0.5 \times 0.4 \times 0.3$} \\
\hline$\theta$ range for data collection & \multicolumn{2}{|l|}{2.02 to 28.23} \\
\hline Index ranges & \multicolumn{2}{|c|}{$-12 \leq h \leq 14,-13 \leq k \leq 13,0 \leq l \leq 14$} \\
\hline Reflections collected & \multicolumn{2}{|l|}{17057} \\
\hline Independent reflections & \multicolumn{2}{|c|}{$4990\left[R_{\mathrm{int}}=0.0228\right]$} \\
\hline Completeness to $\theta=28.23^{\circ}$ & \multicolumn{2}{|l|}{$92.0 \%$} \\
\hline Absorption correction & \multicolumn{2}{|l|}{ Empirical } \\
\hline Refinement method & \multicolumn{2}{|c|}{ Full-matrix least-squares on $F^{2}$} \\
\hline Data / restraints / parameters & \multicolumn{2}{|l|}{$4990 / 0 / 217$} \\
\hline Goodness-of-fit on $F^{2}$ & \multicolumn{2}{|l|}{1.078} \\
\hline Final $R$ indices $[I>2 \sigma(I)]$ & \multicolumn{2}{|c|}{$R_{1}=0.0209, w R_{2}=0.0524$} \\
\hline$R$ indices (all data) & \multicolumn{2}{|c|}{$R_{1}=0.0221, w R_{2}=0.0530$} \\
\hline Largest diff. peak and hole $\left(\mathrm{e} \cdot \AA^{-3}\right)$ & \multicolumn{2}{|c|}{1.174 and -0.738} \\
\hline
\end{tabular}


Table C17. Crystal data and structure refinement for $\mathbf{2 3}$

\begin{tabular}{|c|c|}
\hline Empirical formula & $\mathrm{C}_{34} \mathrm{H}_{70} \mathrm{I}_{2} \mathrm{LiN}_{8} \mathrm{Sm} \cdot \mathrm{C}_{7} \mathrm{H}_{8}$ \\
\hline Formula weight & 1094.22 \\
\hline Temperature (K) & $133(2) \mathrm{K}$ \\
\hline$\lambda(\AA)$ & 0.71073 \\
\hline Crystal system & monoclinic \\
\hline Space group & $C 2$ \\
\hline \multirow[t]{3}{*}{ Unit cell dimensions $\left(\AA,^{\circ}\right)$} & $a=31.630(6)$ \\
\hline & $b=9.709(19)$ \\
\hline & $c=18.853(4)$ \\
\hline Volume $\left(\AA^{3}\right), Z$ & $4833.0(17), 8$ \\
\hline Density (calculated) $\left(\mathrm{g} / \mathrm{cm}^{3}\right)$ & 1.513 \\
\hline Absorption coefficient $\left(\mathrm{mm}^{-1}\right)$ & 2.528 \\
\hline $\mathrm{F}(000)$ & 2216 \\
\hline Crystal size $\left(\mathrm{mm}^{3}\right)$ & $0.3 \times 0.4 \times 0.3$ \\
\hline$\theta$ range for data collection & 2.16 to 24.62 \\
\hline Index ranges & $-14 \leq h \leq 35,-10 \leq k \leq 11,-21 \leq l \leq 21$ \\
\hline Reflections collected & 4935 \\
\hline Independent reflections & $4285\left[R_{\mathrm{int}}=0.0445\right]$ \\
\hline Completeness to $\theta=24.62^{\circ}$ & $92.7 \%$ \\
\hline Absorption correction & Empirical \\
\hline Refinement method & Full-matrix least-squares on $F^{2}$ \\
\hline Data / restraints / parameters & 4285 / 1 / 502 \\
\hline Goodness-of-fit on $F^{2}$ & 1.012 \\
\hline Final $R$ indices $[I>2 \sigma(I)]$ & $R_{1}=0.0212, w R_{2}=0.0507$ \\
\hline$R$ indices (all data) & $R_{1}=0.0224, w R_{2}=0.0510$ \\
\hline Largest diff. peak and hole $\left(\mathrm{e} \cdot \AA^{-3}\right)$ & 1.127 and -0.662 \\
\hline
\end{tabular}


Table C18. Crystal data and structure refinement for $\mathbf{2 4}$

\begin{tabular}{|c|c|}
\hline Empirical formula & $\mathrm{C}_{34} \mathrm{H}_{70} \mathrm{I}_{2} \mathrm{LiN}_{8} \mathrm{Yb} \cdot \mathrm{C}_{7} \mathrm{H}_{8}$ \\
\hline Formula weight & 1116.9 \\
\hline Temperature (K) & $133(2) \mathrm{K}$ \\
\hline$\lambda(\AA)$ & 0.71073 \\
\hline Crystal system & monoclinic \\
\hline Space group & $C 2$ \\
\hline \multirow[t]{3}{*}{ Unit cell dimensions $\left(\AA,^{\circ}\right)$} & $a=31.405(6)$ \\
\hline & $\beta=123.14(3)$ \\
\hline & $c=18.730(4)$ \\
\hline Volume $\left(\AA^{3}\right), Z$ & $4768.7(17)$ \\
\hline Density (calculated) $\left(\mathrm{g} / \mathrm{cm}^{3}\right)$ & $1.565,8$ \\
\hline Absorption coefficient $\left(\mathrm{mm}^{-1}\right)$ & 3.292 \\
\hline $\mathrm{F}(000)$ & 2248 \\
\hline Crystal size $\left(\mathrm{mm}^{3}\right)$ & $0.30 \times 0.20 \times 0.20$ \\
\hline$\theta$ range for data collection & 2.24 to 24.73 \\
\hline Index ranges & $-36 \leq h \leq 30,0 \leq k \leq 11,0 \leq l \leq 21$ \\
\hline Reflections collected & 4217 \\
\hline Independent reflections & $4217\left[R_{\mathrm{int}}=0.0000\right]$ \\
\hline Completeness to $\theta=24.73^{\circ}$ & $96.9 \%$ \\
\hline Absorption correction & Empirical \\
\hline Refinement method & Full-matrix least-squares on $F^{2}$ \\
\hline Data / restraints / parameters & $4217 / 1 / 502$ \\
\hline Goodness-of-fit on $F^{2}$ & 0.913 \\
\hline Final $R$ indices $[I>2 \sigma(I)]$ & $R_{1}=0.0254, w R_{2}=0.0529$ \\
\hline$R$ indices (all data) & $R_{1}=0.0290, w R_{2}=0.0550$ \\
\hline Largest diff. peak and hole $\left(\mathrm{e} \cdot \AA^{-3}\right)$ & 1.450 and -0.478 \\
\hline
\end{tabular}




\section{References}

[1] a) C. S. Reiners, Chem. uns. Zeit 2001, 2, 110; b) Nomenclature of Inorganic Chemistry. Recommendations 1990 Ed. G. J. Leigh, International Union of Pure and Applied Chemistry, Blackwell Scientific Publications: Oxford, London, Edinburgh, Boston, Melbourne, 1990, chap. I-3.8.

[2] F. Szabadváry in Handbook on the Physics and Chemistry of Rare Earths Eds. K. A. Gschneider, Jr., L. Eyring, Elsevier Science Publishers B. V.: Amsterdam, 1988, vol. 11, chap. 73.

[3] J. E. Huheey, E. A. Keiter, R. L. Keiter Inorganic Chemistry: Principles of Structure and Reactivity, $4^{\text {th }}$ ed.; Harper Collins College Publishers: New York, 1993, chap. 14.

[4] G. Wilkinson, J. M. Birmingham, J. Am. Chem. Soc. 1954, 76, 6210.

[5] H. Schumann, J. A. Meese-Marktscheffel, L. Esser, Chem. Rev. 1995, 95, 865.

[6] J. L. Atwood, K. D Smith, J. Chem. Soc., Dalton Trans. 1973, 2487.

[7] H. B. Kagan, J. Collin, J. L. Namy, C. Bied, F. Dallemer, A. Lebrun, J. Alloys Comp. 1993, 192, 191.

[8] R. Anwander in Top. Organomet. Chem., Springer Verlag: Berlin, Heidelberg, New York, 1999, vol. 2 Lanthanide: Chemistry and Use in the Organic Synthesis, Ed. S. Kobayashi.

[9] Lanthanide Probes in Life, Chemical and Earth Sciences, Theory and Practice; Eds. J.-C. G. Bünzly, C. R. Choppin, Elsevier: Amsterdam, 1989.

[10] W. J. Evans, B. L. Davis, J. W. Ziller, Inorg. Chem. 2001, 40, 6341.

[11] W. J. Evans, B. L. Davis, Chem. Rev. 2002, 102, 2119.

[12] F. Nief, Eur. J. Inorg. Chem. 2001, 891 and references therein. 
[13] L. H. Gade, Acc. Chem. Res. 2002, 35, 575 and references therein.

[14] P. W. Roesky, Eur. J. Inorg. Chem. 2001, 1653 and references therein.

[15] L. Lee, D. J. Berg, F. W. B. Einstein, R. J. Batchelor, Organometallics 1997, 16, 1819.

[16] P. W. Roesky, Chem. Ber. 1997, 130, 859.

[17] a) R. Duchateau, C. T. van Wee, A. Meetsma, J. H. Teuben, J. Am. Chem. Soc. 1993, 115, 4931; b) F. T. Edelmann, Coord. Chem. Rev. 1994, 137, 403.

[18] G. W. Rabe, C. D. Berube, G. P. A. Yap, Inorg. Chem. 2001, 40, 2682.

[19] N. Marques, A. Sella, J. Takats, Chem. Rev. 2002, 102, 2137 and references therein.

[20] J. Arnold, C. G. Hoffman, D. Y. Dawson, F. J. Hollander, Organometallics 1993, 12,3645 .

[21] F. T. Edelmann, D. M. M. Freckmann, H. Schumann, Chem. Rev. 2002, 102, 1851 and references therein.

[22] W. E. Piers, D. J. H. Emslie, Coord. Chem. Rev. 2002, 233-234, 131.

[23] R. G. Pearson, J. Am. Chem. Soc. 1963, 85, 3533.

[24] F. A. Cotton, G. Wilkinson, C. A. Murillo, M. Bochmann Advanced Inorganic Chemistry, $6^{\text {th }}$ ed.; John Wiley \& Sons: New York 1999, chap.19.

[25] a) G. W. Rabe, J. Riede, A. Schier, Organometallics 1996, 15, 439; b) M. D. Fryzuk, G. Giesbrecht, S. J. Rettig, Organometallics 1996, 15, 3329.

[26] S. Arndt, J. Okuda, Chem. Rev. 2002, 102, 1953 and references therein.

[27] P. L. Watson, T. H. Tulip, I. Williams, Organometallics 1990, 9, 1999.

[28] W. P. Kretschmer, J. H. Teuben, S. I. Troyanov, Angew. Chem. 1998, 110, 92; Angew. Chem. Int. Ed. 1998, 37, 88. 
[29] T. J. Marks, R. D. Ernst in Comprehensive Organometallic Chemistry $2^{\text {nd }}$ ed.; F. G. A. Stone, E. W. Abel, Eds.; Pergamon Press: Oxford, U.K., 1995, chap. 21.

[30] L. W. M. Lee, W. E. Piers, M. R. J. Elsegood, W. Clegg, M. Parvez, Organometallics 1999, 18, 2947.

[31] Y. Yao, Y. Zhang, Q. Shen, K. Yu, Organometallics 2002, 21, 819.

[32] D. Neculai, H. W. Roesky, A. M. Neculai, J. Magull, H.-G. Schmidt, M. Noltemeyer, J. Organomet. Chem. 2002, 643, 47.

[33] C. J. Schaverien, Adv. Organomet. Chem. 1994, 36, 283.

[34] F. T. Edelmann in Comprehensive Organometallic Chemistry $2^{\text {nd }}$ ed.; F. G. A. Stone, E. W. Abel, Eds.; Pergamon Press: Oxford, U.K., 1995, chap. 2.

[35] J. D. Corbett, Inorg. Chem. 2000, 39, 5178 and references therein.

[36] a) F. G. N. Cloke, Chem. Soc. Rev. 1993, 17 and references therein; b) P. L. Arnold, F. G. N. Cloke, P. B. Hitchcock, Chem. Commun. 1997, 482.

[37] P. L. Arnold, F. G. N. Cloke, P. B. Hitchcock, J. F. Nixon, J. Am. Chem. Soc. 1996, 118, 7630.

[38] a) P. L. Arnold, F. G. N. Cloke, J. F. Nixon, Chem. Commun. 1998, 797; b) G. K. B. Clenstsmith, F. G. N. Cloke, J. C. Green, J. Hanks, P. B. Hitchcock, J. F. Nixon, Angew. Chem. 2003, 115, 1068; Angew. Chem. Int. Ed. 2003, 42, 1038.

[39] M. N. Bochkarev, I. L. Fedushkin, A. A. Fagin, T. V. Petrovskaya, J. W. Ziller, R. N. R. Broomhall-Dillard, W. J. Evans, Angew. Chem. 1997, 109, 123; Angew. Chem. Int. Ed. 1997, 36, 133.

[40] I. L. Fedushkin, F. Girgsdies, H. Schumann, M. N. Bochkarev, Eur. J. Inorg. Chem. 2001, 2405.

[41] M. C. Cassani, D. J. Duncalf, M. F. Lappert, J. Am. Chem. Soc. 1998, 120, 12958. 
[42] G. Meyer, Chem. Rev., 1998, 88, 93.

[43] a) K. C. Hultzsch, T. S. Spaniol, J. Okuda, Organometallics 1997, 16, 4845; b) T. Gröb, G. Seybert, W. Massa, F. Weller, R. Palaniswami, A. Greiner, K. Dehnicke, Angew. Chem. 2000, 112, 4542; Angew. Chem. Int. Ed. 2000, 39, 4373.

[44] a) B. J. O'Keefe, M. A. Hillmyer, W. B. Tolman, J. Chem. Soc., Dalton Trans. 2001, 2215; b) D. Barbier-Baudry, S. Heiner, M. M. Kubicki, E. Vigier, M. Visseaux, Organometallics 2001, 20, 4207.

[45] P. W. Roesky, U. Denninger, C. L. Stern, T. J. Marks, Organometallics 1997, 16, 4486.

[46] P.-F. Fu, L. Brard, Y. Li, T. J. Marks, J. Am. Chem. Soc. 1995, 117, 7157.

[47] a) Shapiro, P. J.; Bunel, E.; Schaefer, W. P.; Bercaw, J. E. Organometallics 1990, 9, 867; b) K. C. Hultzsch, P. Voth, K. Beckerle, T. S. Spaniol, J. Okuda, Organometallics 2000, 19, 228; c) P. G. Hayes, W. E. Piers, R. McDonald, J. Am. Chem. Soc. 2002, 124, 2132; d) Z. Hou, Y. Wakatsuki, Coord. Chem. Rev. 2002, 231,1 .

[48] K. N. Harrison, T. J. Marks, J. Am. Chem. Soc. 1992, 117, 7157.

[49] M. R. Bürgstein, H. Berberich, P. W. Roesky, Organometallics 1998, 17, 1452.

[50] G. A. Molander, P. J. Nichols, J. Am. Chem. Soc. 1995, 117, 4415.

[51] a) M. E. Thomson,; S. M. Baxter, A. R. Bulls, B. J. Burger, M. C. Nolan, B. D. Santasiero, W. P. Schaefer, J. E. Bercaw, J. Am. Chem. Soc. 1987, 109, 203; b) I. Castillo, T. D. Tilley, J. Am. Chem. Soc. 2001, 123, 10526.

[52] H. C. Aspinall, Chem. Rev. 2002, 102, 1807 and references therein.

[53] H. Maas, A. Currao, G. Calzaferri, Angew. Chem. 2002, 114, 2607; Angew. Chem. Int. Ed. 2002, 41, 2495.

[54] J. Scholz, H. Görls, H. Schumann, R. Weimann, Organometallics 2001, 20, 4394. 
[55] Z. Lu, G. P. A. Yap, D. S. Richeson, Organometallics 2001, 20, 706.

[56] H.-S. Chan, H.-W. Li, Z. Xie, Chem. Commun. 2002, 652.

[57] S. Bambirra, M. J. R. Brandsma, E. A. C. Brussee, A. Meetsma, B. Hessen, J. H. Teuben, Organometallics 2000, 19, 3197.

[58] G. J. P. Britovsek, V. C. Gibson, D. F. Wass, Angew. Chem., 1999, 111, 448; Angew. Chem. Int. Ed. 1999, 38, 428.

[59] L. Bourget-Merle, M. F. Lappert, J. R. Severn, Chem. Rev. 2002, 102, 3032 and references therein.

[60] H. van der Heijden, C. J. Schaverien, A. G. Orpen, Organometallics 1989, 8, 255.

[61] A. M. Neculai, H. W. Roesky, D. Neculai, J. Magull, Organometallics 2001, 20, 5501.

[62] P. G. Hayes, W. E. Piers, L. W. M. Lee, L. K. Knight, M. Parvez, M. R. J. Elsegood, W. Clegg, Organometallics 2001, 20, 2533.

[63] a) A. Bohnsack, G. Meyer, Z. Anorg. Allg. Chem. 1996, 622, 173; b) D. S. Dudis, J. D. Corbett, S.-J. Hwu, Inorg. Chem. 1986, 25, 3434; c) H. H. Karsch, V. Graf, M. Reisky, E. Witt, Eur. J. Inorg. Chem. 1998, 1403.

[64] a) D. W. Randall, S. George DeBeer, P. L. Holland, B. Hedman, K. O. Hodgson, W. B. Tolman, E. L. Solomon, J. Am. Chem. Soc. 2000, 122, 11632; b) L. Deng, R. Schmid, T. Ziegler, Organometallics 2000, 19, 3069.

[65] G. B. Nikiforov, H. W. Roesky, T. Labahn, D. Vidovic, D. Neculai, Eur. J. Inorg. Chem. 2003, 433.

[66] D. Neculai, A. M. Neculai, H. W. Roesky, J. Magull, R. Herbst-Irmer Organometallics, 2003, 22, 2279.

[67] D. Neculai, unpublished results.

[68] P. B. Hitchcock, M. F. Lappert, S. Tian, J. Chem. Soc., Dalton Trans. 1997, 1945. 
[69] R. D. Rogers, R. V. Bynun, J. L. Atwood, J. Organomet. Chem. 1980, 192, 65.

[70] W. Chen, G. Lin, J. Xia, G. Wie, Y. Zhang, Z. Jin, J. Organomet. Chem. 1994, 467, 75.

[71] a) A. L. McKnight, R. M. Waymouth, Chem. Rev. 1998, 98, 2587; b) J.-F. Carpentier, V. P. Maryin, J. Luci, R. F. Jordan, J. Am. Chem. Soc. 2001, 123, 898; c) R. J. Keaton, K. C. Jayaratne, J. C. Fettinger, L. R. Sita, J. Am. Chem. Soc. 2000, 122, 12909; d) W. J. Evans, D. A. Cano, M. A. Greci, J. W Ziller, Organometallics 1999, 18, 1381.

[72] J. R. Hagadorn, J. Arnold, Organometallics 1996, 15, 984.

[73] J. G. Ghotra, M. B. Hursthouse, A. J. Welch, J. Chem. Soc. Chem. Commun. 1973, 669 .

[74] A. M. Neculai, D. Neculai, G. Nikiforov, H. W. Roesky, J. Magull, C. Schlicker, R. Herbst-Irmer, M. Noltemeyer, Eur. J. Inorg. Chem., in press.

[75] D. A. Evans, Z. K. Sweeney, T. Rovis, J. S. Tedrow, J. Am. Chem. Soc. 2001, 123, 12095 and references therein.

[76] S. Kobayashi, S. Nagayama, J. Am. Chem. Soc. 1998, 120, 2985.

[77] S. Kobayashi, T. Tsuchiya, I. Komoto, J. Matsuo, J. Organomet. Chem. 2001, $624,392$.

[78] H. Schumann, J. A. Meese-Marktscheffel, A. Dietrich, F. A. Goerlitz, J. Organomet. Chem. 1992, 430, 299.

[79] H. Schumann, J. A. Meese-Marktscheffel, A. Dietrich, J. Organomet. Chem. 1989, 37, C5.

[80] a) H. Dorn, E. F. Murphy, S. A. A. Shah, H. W. Roesky, J. Fluorine Chem. 1997, 86, 121; b) E. F. Murphy, H. W. Roesky, Chem. Rev. 1997, 97, 3425; c) Z. Xie, K. Chui, Q. Yang, T. C. W. Mak, J. Sun, Organometallics 1998, 17, 3937. 
[81] A. Herzog, H. W. Roesky, F. Jäger, A. Steiner, M. Noltemeyer, Organometallics 1996, 15, 909.

[82] P. Yu, E. F. Murphy, H. W. Roesky, P. Lubini, H.-G. Schmidt, M. Noltemeyer, Organometallics 1997, 16, 313.

[83] X. Verdaguer, U. E. W. Lange, M. T. Reding, S. L. Buchwald, J. Am. Chem. Soc. 1996, 118,6784 .

[84] H. Schumann, M. R. Keitsch, J. Winterfeld, J. Demtschuk, J. Organomet. Chem. 1996, 525, 279.

[85] H. C. Clark, R. J. O’Brien, J. Trotter, J. Chem. Soc. 1964, 2332.

[86] E. F. Murphy, P. Yu, S. Dietrich, H. W. Roesky, E. Parisini, M. Noltemeyer, J. Chem. Soc., Dalton Trans. 1996, 18, 1983 and references therein.

[87] M. Corradi, M. A. D. McGowan, P. C. McGowan, M. Thornton-Pett, Eur. J. Inorg. Chem. 2002, 2362.

[88] a) W. J. Evans, J, C. Brady, J. W. Ziller, J. Am. Chem. Soc. 2001, 123, 7711 and references therein; b) W. A. Herrmann, R. Anwander, F. C. Munck, W. Scherer, F. Dufaud, N. W. Huber, G. R. J. Artus, Z. Naturforsch. 1994, B49, 1789.

[89] a) H. Schumann, E. C. E. Rosenthal, G. Kociok-Köhn, G. A. Molander, J. Winterfeld, J. Organomet. Chem. 1995, 496, 233; b) Y. Mu, W. E. Piers, M.-A. McDonald, M. J. Zaworotko, Can. J. Chem. 1995, 73, 2233; c) M. Westerhausen, M. Hartmann, A. Pfitzner, H. Schwartz, Z. Anorg. Allg. Chem. 1995, 621, 837.

[90] M. Niemeyer, Eur. J. Inorg. Chem. 2001, 1969.

[91] C. Cui, H. W. Roesky, H.-G. Schmidt, M. Noltemeyer, H. Hao, F. Cimpoesu, Angew. Chem. 2000, 112, 4444; Angew. Chem. Int. Ed. 2000, 39, 4274.

[92] A. M. Neculai, D. Neculai, H. W. Roesky, J. Magull, M. Baldus, O. Andronesi, M. Jansen, Organometallics 2002, 21, 2590. 
[93] M. H. Chisholm, J. C. Huffman, K. Phomhrai, J. Chem. Soc., Dalton Trans. 2001, 224.

[94] a) E. R. Andrew, A. Bradbury, R. G. Eades, Nature 1958, 182, 1659; b) M. Baldus, T. O. Levante, B. H. Meier, Z. Naturforsch. 1994, B49, 88.

[95] The DFT calculations were performed using the ADF package a) E. J. Baerends, D. E. Ellis, P. Ros, Chem. Phys., 1973, 2, 41; b) L. Versluis, T. Ziegler, J. Chem. Phys. 1988, 322, 88; c) G. T. Velde, E. J. Baerends, J. Comput. Phys., 1992, 99, 84; using relativistic corrections for the non-hydrogen atoms using ZORA formalism d) E. van Lenthe, E. J. Baerends, J Snijders, G. J. Chem. Phys. 1994, 101, 9783; e) E. van Lenthe, J. G. Snijders, E. J Baerends, J. Chem. Phys. 1996, 105, 6505; f) E. van Lenthe, A. E. Ehlers, E. J. Baerends, J. Chem. Phys. 1999, 110, 8943 g) C. Fonseca Guerra, J. G. Snijders, G. T. Velde, E. J. Baerends, Theor. Chem. Acc. 1998, 99, 391;

[96] See ring displacement reactions with participation of $\operatorname{Ln}(0)$ compounds in ref. 34.

[97] D. Neculai, H. W. Roesky, A. M. Neculai, J. Magull, B. Walfort, D. Stalke, Angew. Chem., 2002, 114, 4470; Angew. Chem. Int. Ed. 2002, 41, 4294.

[98] C. Bergquist, B. M. Bridgewater, C. J. Harlan, K. R. Norton, R. A. Friesner, G. Parkin, J. Am. Chem. Soc. 2000, 122, 10581.

[99] a) M. H. Chisholm, J. Galucci, K. Phomhrai, Inorg. Chem. 2002, 41, 2785; b) B. M. Chamberlain, M. Cheng, D. R. Moore, T. M. Ovitt, E. B. Lobkovsky, G. W. Coates, J. Am. Chem. Soc. 2001, 123, 3229; c) M. Cheng, A. B. Attygalle, E. B. Lobkovsky, G. W. Coates, J. Am. Chem. Soc. 1999, 121, 11583.

[100]A restricted hybrid HF-DFT SCF calculation was performed using Pulay DIIS extrapolation for 21 using the Spartan '02 Quantum Mechanics Program; Wavefunction Developers: B. J. Deppmeier, A. J. Driessen, T. S. Hehre, W. J. Hehre, J. A. Johnson, P. E. Klunzinger, J. M. Leonard, I. N. Pham, W. J. Pietro, J. Yu; Q-Chem Developers: J. Kong, C. A. White, A. I. Krylov, C. D. Sherrill, R. D. Adamson, T. R. Furlani, M. S. Lee, A. M. Lee, S. R. Gwaltney, T. R. Adams, C. 
Ochsenfeld, A. T. B. Gilbert, G. S. Kedziora, V. A. Rassolov, D. R. Maurice, N. Nair, Y. Shao, N. A. Besley, P. E. Maslen, J. P. Dombroski, H. Dachsel, W. M. Zhang, P. P. Korambath, J. Baker, E. F. C. Byrd, T. van Voorhis, M. Oumi, S. Hirata, C. P. Hsu, N. Ishikawa, J. Florian, A. Warshel, B. G. Johnson, P. M. W. Gill, M. Head-Gordon, J. A. Pople.

[101]T. Dube, M. Ganesan, S. Conoci, S. Gambarotta, G. P. A. Yap, Organometallics 2000, 19, 3716 .

[102]a)K. Asakura, M. Nishiura, T. Imamoto, Kidorui 1999, 34, 1641, CA 241131-113; b) H. M. Artelt, T. Schleid, G. Meyer, Z. Anorg. Allg. Chem. 1992, 102, 941; c) R. Anwander, F. C. Munk, T. Priermeier, W. Scherer, O. Runte, W. A. Herrmann, Inorg. Chem. 1997, 36, 3545.

[103]a) R. Fischer, D. Walter, P. Gerhardt, H. Gores, Organometallics 2000, 19, 2532; b) J. M. Smith, R. J. Lachiotte, P. L. Holland, Chem. Commun. 2001, 1542; c) C. S. Weinert, P. E. Fanwick, I. P. Rotwell, Organometallics 2002, 21, 484.

[104]a) H. Schumann, M. R. Keitsch, J. Demtschuk, G. A. Molander J. Organomet. Chem. 1999, 582, 70; b) R. D. Rogers, R. D. Etzenhouser, Acta Crystallogr. Sect. C 1988, 44, 1400; c) P. W. Roesky, J. Organomet. Chem. 2000, 603, 161.

[105]a) C. Eaborn, P. B. Hitchcock, K. Izod, J. D. Smith, J. Am. Chem. Soc. 1994, 116, 12071; b) Z. Hou, T. Koizumi, M. Nishiura, Y. Wakatsuki, Organometallics 2001, 20, 3323.

[106]A. G. Avent, A. V. Khvostov, P. B. Hitchcock, M. F. Lappert, Chem. Commun. 2002, 1410.

[107]D. F. Evans, G. F. Fazakerley, R. F. Phillips, J. Chem. Soc. (A) 1971, 1931.

[108]M. Niemeyer, Acta Crystallogr. Sect. E 2001, 57, 578.

[109]a) C. Schnitter, H. W. Roesky, C. Röpken, R. Herbst-Irmer, H.-G. Schmidt, M. Noltemeyer, Angew. Chem., 1998, 110, 2059; Angew. Chem. Int. Ed. 1998, 37, 
1952; b) S. D. Waezsada, F. Q. Liu, C. E. Barnes, H. W. Roesky, M. Montero, I. Uson, Angew. Chem., 1997, 109, 2738; Angew. Chem. Int. Ed. 1998, 36, 2625.

[110]D. D. Perrin, W. L. F Armarego, Purification of Laboratory Chemicals, $3^{\text {rd }}$ Edn., Pergamon Press, London, 1988.

[111]a) Bruker, 1999. SAINT+.Version 6.02(includes XPREP and SADABS). Bruker Analytical X-ray Instruments Inc., Madison, Wisconsin, USA; b) Stoe, 2000.XArea. Stoe\&Cie. GmbH, Darmstadt, Germany.

[112]a) G. M. Sheldrick, Acta Crystallogr. Sect. A 1990, 46, 467; b) G. M. Sheldrick, SHELXL-97, Program for Crystal Structure Refinement, 1997, University of Göttingen.

[113] G. B. Deacon, T. D. Tuong, D. L. Wilkinson, F. G. N. Cloke in Synthetic Methods of Organometallic and Inorganic Chemistry, Ed. W. A. Herrmann, G. Brauer, Georg Thieme Verlag: Stuttgart, 1997, vol. 6, 34.

[114]Handbuch der präparativen Anorganischen Chemie, 3 Aufl., Ed. G. Brauer, Ferdinand Enke Verlag: Stuttgart, 1978, 20, 1077.

[115]J. H. Freeman, M. L. Smith in Synthetic Methods of Organometallic and Inorganic Chemistry, W. Herrmann, G. Brauer, Georg Thieme Verlag Stuttgart, 1997, vol. 6,32 .

[116]D. C. Bradley, I. S. Harding, A. D. Keefe, M. Motevalli, D. H. Zheng, J. Chem. Soc., Dalton Trans. 1996, 3931.

[117]J. L. W. Pohlmann, F. E. Brinckmann, Z. Naturforsch. 1965, B20, 5.

[118]E. Krause, Ber. Dtsch. Chem. Ges. 1918, 51,1447.

[119]B. Hübler-Blank, M. Witt, H. W. Roesky, J. Chem. Educ. 1993, 70, 408. 


\section{Curriculum Vitae}

Ana-Mirela Neculai, born on $27^{\text {th }}$ Februar 1975 in Slobozia, Ialomita, Romanian

Nationality

Marital status

Parents

Education

1981-1989

1989-1993

$\underline{\text { Hochschulausbildung }}$

1993-1997

June 1997

October 1997

June 1999

June 2000

April 2003 romanian

maried

Vasile Gugulea

Maria Gugulea, geb. Dragusin

Primary and secondary school, School No. 10, Calarasi, Romania

Stirbey Voda High School, Calarasi, Rumänien

Faculty of Chemistry, University of Bucharest, Romania Licence in Chemistry

Faculty of Chemistry, University of Bucharest, Romania Master of Science

Ph. D. Student in the research group of Prof. Dr. h. c. mult. H. W. Roesky 